\title{
NÍVEIS DE NITROGÊNIO E PROPORÇÕES DE NITRATO E AMÔNIO AFETANDO PRODUÇÃO, ATIVIDADE DA REDUTASE DO NITRATO E COMPOSIÇÃO DE TRÊS GRAMÍNEAS FORRAGEIRAS
}

\section{JOÃO BATISTA RODRIGUES DE ABREU \\ Zootecnista}

Orientador: Prof. Dr. Francisco Antonio Monteiro

Dissertação apresentada à Escola Superior de Agricultura "Luiz de Queiroz", da Universidade de São Paulo, para obtenção do título de Mestre em Agronomia, Área de Concentração: Ciência Animal e Pastagens.

P I R A C I C A B A

Estado de São Paulo - Brasil

Novembro - 1994 
Dados internacionais de Catalogação na Publicação (CIP)

Divisão de Biblioteca e Documentação - CAMPUS "LUIZ DE QUEIROZ"JUSP

Abreu, João Batista Rodrigues de

Niveis de nitrogênio e proporçōes de nitrato e amönio afetando produção, atividade na redutase do nitrato e composição de três grami neas forrageiras. Piracicaba, 1995.

$103 p$.

Tese - ESALQ

Bibliografia.

1. Graminea forrageira - Adubação nitrogenada 2. Macronutriente em gramínea forrageira 3. Matéria seca - Produção 4. Redutase de nitrato I. Escola Supericr de Agricultura Luiz de Queiroz, Piracicaba

$\operatorname{CDD} \quad 633.2$ 


\section{NÍVEIS DE NITROGÊNIO E PROPORÇÕES DE NITRATO E AMÔNIO AFETANDO PRODUÇÃO, ATIVIDADE DA REDUTASE DO NITRATO E COMPOSIÇÃO DE TRÊS GRAMÍNEAS FORRAGEIRAS}

Aprovada em: 28.11.1995

Comissão julgadora:

Prof. Dr. FRANCISCO ANTONIO MONTEIRO

Dr. JOAQUIM CARLOS WERNER

Prof. Dr.QUIRINO AUGUSTO DE CAMARGO CARMELO
ESALQ/USP

IZ/SAA

ESALQ/USP

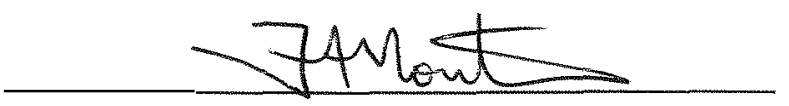

Prof. Dr.FRANCISCO ANTONIO MONTEIRO

Orientador 
Aos meus pais "in memorian" e aos meus irmãos,

OFEREÇO.

A minha esposa TERESA CRISTINA e aos nossos filhos JOÃO PAULO e ANA CAROLINA,

DEDICO. 


\section{AGRADECIMENTOS}

Ao Prof. Dr. Francisco Antonio Monteiro pela brilhante orientação e principalmente pela amizade desenvolvida.

Ao Prof. Dr. Quirino Augusto de Camargo Carmelo, pela amizade, disponibilidade, ajuda e sugestões apresentadas ao trabalho.

Ao Prof. Dr. Antonio Roque Dechen pela amizade e constante incentivo que manifestava.

Ao Prof. Dr. Luiz Carlos Basso pelas sugestões e auxílio prestados para metodologia de determinação do nitrogênio.

Ao Prof. Dr. Arnaldo Antônio Rodella pela ajuda e sugestões na elaboração das soluções nutritivas e, principalmente pela amizade.

Ao amigo Waldomiro Barione Junior, pela amizade e auxílio nas análises estatísticas.

À todos os professores do curso de Ciência Animal e Pastagens pela dedicação e conhecimentos transmitidos.

Aos estagiários da área de Nutrição Mineral de Plantas, Mauro Nobuo Ono, Roberto Ferrarezi Risolia e Carlos Augusto Martins Vieira pela ajuda, dedicação e amizade.

Aos amigos de curso, especialmente, Allan Kardec Braga Ramos, José Alfredo Salinas Daiub, Marcela Abado, Verônica Oliveira Vianna e a todos pelo companheirismo e ajuda prestada para realização deste trabalho.

Aos funcionários do Laboratório de Nutrição Mineral de Plantas

Ednéia Cristina Sceroino Mandoni, Fernando Éder Ré, Lurdes Aparecida Dário de 
Gonzales, Mirtes Ventura Sesso, Nivanda Maria de Moura e Sueli Maria Amaral Campos Bovi pela dedicação e apoio para a realização das análises.

Aos Professores do Departamento de Nutrição Animal e Pastagens da Universidade Federal Rural do Rio de Janeiro José Bonifácio de Oliveira Xavier de Menezes, Hélio Ribeiro, Mauro Portela Piña Rodrigues e todos os demais pela ajuda e empenho para que este trabalho pudesse ser realizado.

À Universidade Federal Rural do Rio de Janeiro pela oportunidade concedida para realização deste curso.

À CAPES pelo apoio financeiro e institucional prestado para a realização deste trabalho 


\section{SUMÁRIO}

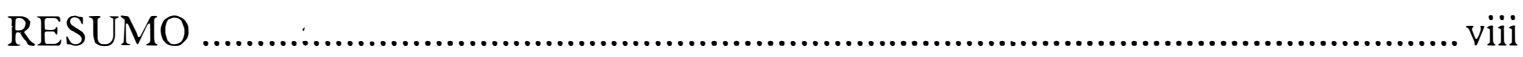

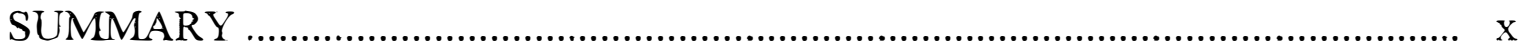

1. INTRODUÇÃ

2. REVISÃO DE LITERATURA ................................................................ 03

2.1. Utilização de nitrogênio em gramíneas forrageiras .................................. 03

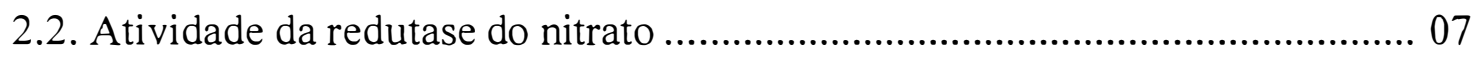

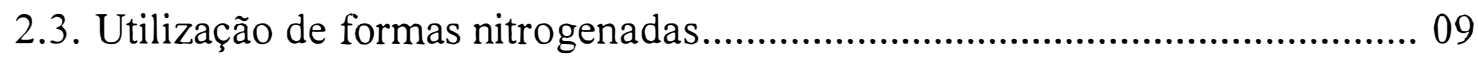

3. MATERIAL E MÉTODOS .................................................................. 13

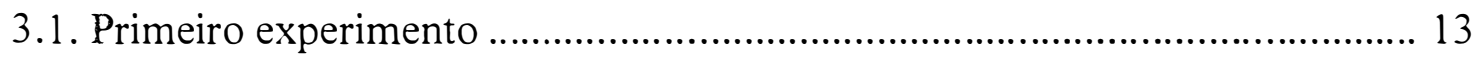

3.1.1. Condições de instalação e condução do experimento ....................... 13

3.1.2. Tratamentos e delineamento experimental .................................. 14

3.1.3. Soluções nutritivas nos tratamentos ............................................ 14

3.1.4. Coleta do material vegetal....................................................... 15

3.2. Segundo experimento .................................................................. 16

3.2.1. Condições de instalação e condução do experimento ........................ 16

3.2.2. Tratamentos e delineamento experimental ................................... 17

3.2.3. Soluções nutritivas nos tratamentos ........................................... 17

3.2.4. Coleta do material vegetal................................................... 18

3.3. Determinações no material vegetal................................................... 19 
3.3.1. Produção de matéria seca..................................................................... 19

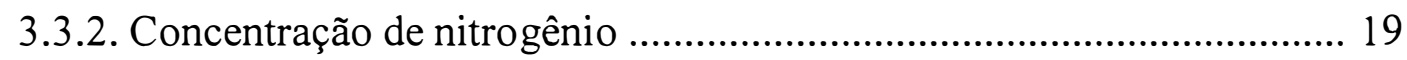

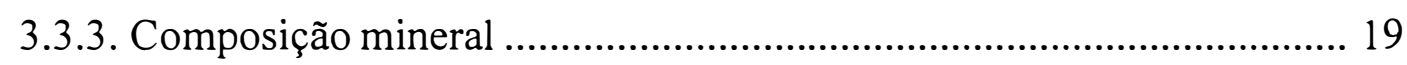

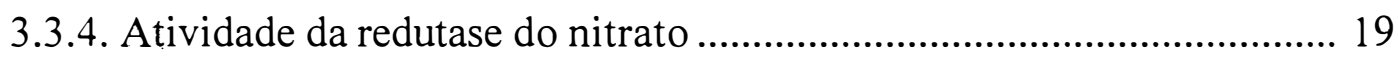

3.3.5. Concentração de nitrogênio nítrico e amoniacal.................................... 20

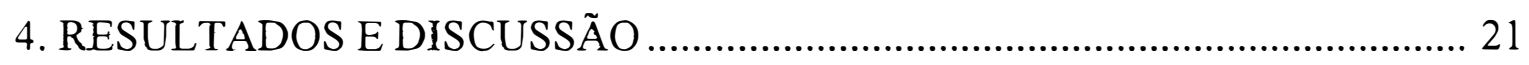

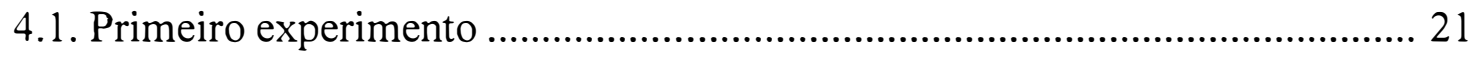

4.1.1. Efeito dos níveis de nitrato sobre o número de perfilhos................... 21

4.1.2. Efeito dos níveis de nitrato sobre a produção de matéria seca ............ 22

4.1.3. Efeito dos níveis de nitrato sobre a concentração de nitrogênio nos

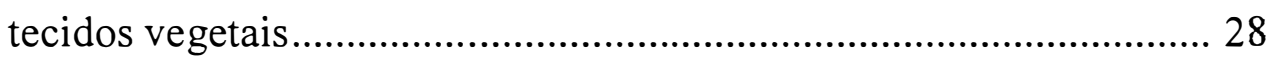

4.1.4. Efeito dos níveis de nitrato sobre a concentração de amônio nos tecidos vegetais .................................................................................. 35

4.1.5. Efeito dos níveis de nitrato sobre a concentração de nitrato nos

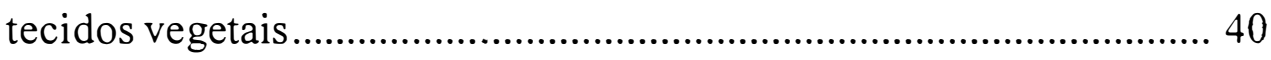

4.1.6. Efeito dos níveis de nitrato sobre a atividade da redutase do nitrato . 45

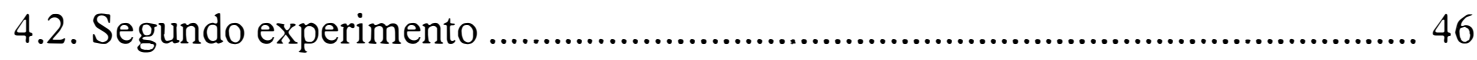

4.2.1. Efeito das proporções de nitrato e amônio sobre o número de perfilhos.

4.2.2. Efeito das proporções de nitrato e amônio sobre a produção de matéria seca

4.2.3. Efeito das proporções de nitrato e amônio sobre a concentração de nitrogênio nos tecidos vegetais 
4.2.4. Efeito das proporções de nitrato e amônio sobre a concentração de amônio nos tecidos vegetais

4.2.5. Efeito das proporções de nitrato e amônio sobre a concentração de nitrato nos tecidos vegetais

4.2.6. Efeito das proporções de nitrato e amônio sobre a atividade da redutase do nitrato

4.2.7. Efeito das proporções de nitrato e amônio sobre a concentração de fósforo nos tecidos vegetais

4.2.8. Efeito das proporções de nitrato e amônio sobre a concentração de potássio nos tecidos vegetais

4.2.9. Efeito das proporções de nitrato e amônio sobre a concentração de cálcio nos tecidos vegetais.

4.2.10. Efeito das proporções de nitrato e amônio sobre a concentração de magnésio nos tecidos vegetais

4.2.11. Efeito das proporções de nitrato e amônio sobre a concentração de enxofre nos tecidos vegetais

5. CONCLUSÕES 92 


\title{
NÍVEIS DE NITROGÊNIO E PROPORÇÕES DE NITRATO E AMÔNIO AFETANDO PRODUÇÃO, ATIVIDADE DA REDUTASE DO NITRATO E COMPOSIÇÃO DE TRÊS GRAMÍNEAS FORRAGEIRAS
}

\author{
Autor: João Batista Rodrigues de Abreu \\ Orientador: Prof. Dr. Francisco Antonio Monteiro
}

RESUMO

Foram realizados dois experimentos com solução nutritiva envolvendo as gramíneas forrageiras Panicum maximum Jacq cv Tanzânia-1, Brachiaria brizantha Stapf cv Marandu e Melinis minutiflora Beauv. O primeiro experimento teve o objetivo de avaliar o efeito dos níveis de nitrato sobre a produção de matéria seca, as concentrações de nitrogênio total, de amônio e de nitrato nas plantas e atividade da redutase do nitrato para as gramíneas. O segundo experimento objetivou estudar o nível de nitrogênio com maiores respostas avaliadas no primeiro, testando as proporções de nitrato e amônio 100/0, 75/25, 50/50, 25/75 e 75/25\% sem cálcio, sobre as mesmas variáveis do primeiro experimento e, incluindo-se as concentrações de macronutrientes.

Os experimentos foram realizados durante a primavera de 1994, em casa-de-vegetação, utilizando solução nutritiva e substrato de sílica. Em ambos, utilizou-se o delineamento de blocos ao acaso, com três repetições. A atividade da redutase do nitrato foi determinada 22 e 47 dias após o início do trabalho, para o primeiro e segundo experimentos, respectivamente, nos horários compreendidos entre 8:00 e 10:00 horas. As plantas foram colhidas 55 e 71 dias após o início de 
aplicação da solução nutritiva para o primeiro e segundo experimentos, respectivamente, sendo separadas as frações da planta: folhas novas, folhas velhas, colmos + bainhas e raízes.

Os resultados mostraram efeitos significativos $(\mathrm{P}<0,05)$ dos níveis de nitrato sobre o número de perfilhos, a produção de matéria seca total, a elevação da concentração de nitrato nos tecidos vegetais e o aumento da atividade da redutase do nitrato de 0,030 para $0,101 \mu \mathrm{g}$ de $\mathrm{N}-\mathrm{NO}_{3} / \mathrm{g}$ de matéria verde.hora ${ }^{-1}$. As proporções de nitrato e amônio 100/0 e 75/25 (-Ca) provocaram aumentos da produção de matéria seca, indicando a necessidade nas plantas, de um equilíbrio catio-ânionico para melhor aproveitar o amônio nesta proporção e uma perfeita adaptação à nutrição nítrica. Estes tratamentos também provocaram maiores concentrações de nitrogênio na matéria seca das plantas. Detectou-se o efeito significativo $(P<0,05)$ da ausência de cálcio sobre o aumento das concentrações de potássio, fósforo e enxofre e a redução das concentrações de magnésio nos tecidos vegetais. 
NITROGEN RATES AND PROPORTIONS OF NITRATE AND AMMONIUN AFFECTING YIELD, NITRATE REDUCTASE ACTIVITY AND COMPOSITION OF THREE FORAGE GRASSES

\author{
Author: João Batista Rodrigues de Abreu \\ Adviser: Prof. Dr. Francisco Antonio Monteiro
}

\title{
SUMMARY
}

Two experiments were carried out in nutritive solutions with the forage grasses Panicum maximum Jacq cv. Tanzânia-1, Brachiaria brizantha Stapf cv. Marandu and Melinis minutiflora Beauv. The first experiment had as objective to evaluate the effects of nitrate rates on dry matter yield, on total nitrogen, ammonium and nitrate concentrations in the plant tissues, and on nitrate reductase activity in each grass. The second experiment was set to study the nitrogen rate with the best responses in the first one to evaluate nitrate / ammonium proportions of 100/0, 75/25, $50 / 50,25 / 75$ and $75 / 25$ with no calcium in the solution. In this experiment the same response variables used in the first one were studied, with the addition of the macronutrient concentrations in the plant tissues.

The experiments were performed during the spring of 1994 , in a greenhouse, by using siliceous substrate. Both experiments were set in completely randomized block design, with three replications. Nitrate reductase activity was determined from 8:00 to 10:00 A.M. at 22 and 47 days after the beginning for the first and second experiments, respectively. Plants were harvested at 55 and 71 days after starting the use of nutritive solutions for the first and second studies, 
respectively. Plants were separated in young leaves, old leaves, stem + sheats and roots.

The results showed the significant $(\mathrm{P}<0,05)$ and positive effects of nitrate rates on number of tillers, on total dry matter yield, on nitrate concentration and on nitrate reductase activity in the plant tissues from 0,03 to $0,101 \mu$ Mols of $\mathrm{N}$ $\mathrm{NO}_{3}{ }^{-}$of fresh matter by hour. The proportions of nitrate / ammonium of 100/75 and 75/25 (minus Ca) encouraged the dry matter yield, suggesting the need of an cation / anion equilibrium in the plant for the best use of ammonium and also a plant adaptation to the nitric nutrition. The same proportions increased the nitrogen concentrations in the plant tissues. Calcium omission in the nutritive solution promoted increases in potassium, phosphorus and sulphur concentrations and decreased magnesium concentrations in the plant tissues. 


\section{INTRODUÇÃO}

O estudo de aspectos da nutrição nitrogenada em gramíneas pode esclarecer pontos ainda não completamente compreendidos das funções metabólicas dos diversos compostos que tem nitrogênio como constituinte, bem como pode fornecer informações importantes sobre a ação do acúmulo destes sobre o aumento de produção forrageira.

A utilização do nitrogênio tem como cosequência final um aumento da produção de forragem. Entretanto, por vezes, apesar do acúmulo desse nutriente, a sua eficiência é baixa, mesmo para plantas com ciclo $\mathrm{C}_{4}$.

O processo enzimático de redução das formas nitrogenadas é importante quando formas nítricas são utilizadas. Ao contrário, quando adubos amoniacais são empregados, a redução enzimática deixa de ser um fator tão importante, porém o acúmulo do amônio é prejudicial ao desenvolvimento das plantas, provocando engrossamento de raízes além de torná-las quebradiças. Desta forma, é necessária a pronta utilização de formas amoniacais, o que determina uma rápida assimilação, a qual não é sempre possível devido à dependência direta de fotoassimilados para que os radicais aminados possam rapidamente ser transformados em proteínas estruturais ou enzimas e, novamente, as formas amínicas e amídicas absorvam o fluxo de amônio absorvido.

A utilização das formas de nitrogênio acarreta algumas situações como acidificação do rizocilindro, quando predomina a absorção de amônio, além de aumentar a absorção de fosfato monovalente e ânions de maneira geral. Ao se utilizar nitrato o inverso pode ocorrer, devido ao balanço de cargas no interior da raiz. 
As formas nitrogenadas, presentes no substrato de crescimento das plantas, apresentam diferenças quanto às perdas, sendo maior para nitrato, que pode ser minimizada em condições de boa aeração do solo. Apesar de existir maior perda por lixiviação de nitrato, é possível reduzí-las em plantas com maior eficiência de absorção, desde que ocorra um fluxo mais contínuo, para manter ativo o sistema enzimático, iniciado pela redutase do nitrato.

A utilização do nitrogênio promove aumento da produção de forragem devido ao maior perfilhamento e às maiores velocidade de elongação e taxa de aparecimento de folhas. O resultado do aumento das três características mencionadas permite o aumento da atividade fotossintética com produção de esqueletos de carbono. Cria-se assim, a condição para a assimilação dos radicais aminados. Do somatório desses eventos decorre o aumento dos pontos de crescimento, com maior velocidade de acúmulo de fitomassa.

A melhor compreensão do metabolismo do nitrogênio e sua interação com os outros nutrientes constitui-se em ferramenta para o aumento da produção de forragem, do animal e, consequentemente, do sistema de produção pecuário.

O presente trabalho teve como objetivos avaliar a produção de matéria seca, o acúmulo de macronutrientes e formas nitrogenadas nas raízes e parte aérea, bem como a atividade da redutase do nitrato, relacionando-os com a produção de matéria seca em gramíneas com elevada e baixa resposta à adubação nitrogenada, sob níveis da forma nítrica e proporções de nitrato/amônio. 


\section{REVISÃO DE LITERATURA}

\subsection{Utilização de nitrogênio em gramíneas forrageiras}

A ação do nitrogênio sobre o aumento da produção de forragem é bem conhecida, como destacou WERNER (1986).

Com o aumento da disponibilidade de nitrogênio ocorre elevação do seu teor nos tecidos vegetais (NOVOA \& LOOMIS, 1981). Estas elevações, entretanto podem ser maiores em períodos de menor disponibilidade de água e temperaturas mais baixas como apontados por PARETAS (1981) ao trabalhar com capim-rhodes e por BRUNET et al. (1988b) quando compararam os Cynodons bermuda cruzada $\mathrm{n}^{\circ} 1$, bermuda da costa e estrela Jamaicano, e o Panicum maximum (Jacq) cv. Likoni, o que está de acordo com RAMOS et al. (1983). Tendência de maior concentração de nitrogênio no período de primavera encontrou PARETAS (1981) ao trabalhar com capim-pangola. Por sua vez, ASPIOLEA \& ARTEGA (1978) destacaram que baixas doses de adubos nitrogenados são insuficientes para aumentar a concentração de nitrogênio total na planta.

VICENTE-CHANDLER (1972), ao comparar sete gramíneas tropicais em condições de tropico úmido, verificou que todas aumentavam seus teores de proteína até $10 \%$, aos 60 dias de crescimento, e os capins gordura e estrela apresentaram elevações mais rápidas do que os capins colonião, braquiária e elefante. 
A conversão da unidade de nitrogênio aplicado em produção de unidade de matéria seca para forrageiras tropicais melhoradas não difere muito, conforme CRESPO et al. (1986), que testando doses de nitrogênio até 800 quilogramas por hectare anualmente para os capins colonião, pangola, estrela comum e elefánte, encontraram valores que estão entre 12 e 15 para as três primeiras forrageiras, podendo chegar a 18, para o capim-elefante. Tendência semelhante encontraram BRUNET et al. (1990) ao avaliarem capins do gênero Cynodon e o capim-guiné likoni, com valores de 11,88 a 14,83, sendo que o Panicum apresentou as maiores conversões, em valor absoluto.

CRESPO (1986), trabalhando com capim-colonião, encontrou valores de 7,1 (inverno) até 83,3 (verão) quilogramas de matéria seca por quilograma de nitrogênio aplicado em condições de irrigação suplementar ao déficit hídrico, constatando a capacidade de resposta à adubação em presença de condições edafoclimáticas adequadas. Para relação de quilogramas de nitrogênio por tonelada de matéria seca produzida, ALVIM et al. (1990a) e BOTREL et al. (1990) encontraram valores de 13,85 para 150 quilogramas de nitrogênio aplicado por hectare.

A extração do nitrogênio, em condições de baixas taxas de crescimento, é de 50 a 100 quilogramas por hectare anualmente, aumentando para 300 a 500 quilogramas com utilização de doses mais elevadas de adubação (MIDDLETON, 1982; CRESPO et al., 1986; e BRUNET et al., 1988a). Este é um fator muito importante sobre a composição da forragem em nitrogênio e outros minerais, sendo o potássio muito importante sob condições de altas doses de adubos nitrogenados (NOVOA \& LOOMIS, 1981; PARETAS, 1981; BRUNET et al., 1988a e BRUNET et al., 1990).

A recuperação do adubo nitrogenado é um aspecto da avaliação econômica, na qual grande parte das pesquisas se concentra, procurando buscar equilíbrio entre doses de adubo, épocas de aplicação, período de crescimento da 
planta, fontes utilizadas e diferenças entre espécies e até variedades (CRESPO et al., 1986).

VICENTE-CHANDLER (1972), através de resultados compilados de diversos trabalhos desenvolvidos em Porto Rico demonstrou que ocorrem recuperações decrescentes com o aumento da dose de nitrogênio. BRUNET et al. (1988b) assinalaram o decréscimo da recuperações de 72,4 para $50,2 \%$, em colonião cv. Likoni, ao ter adubação de 60 a 240 quilogramas de nitrogênio por hectare anualmente. Este resultado demonstrou uma superioridade absoluta sobre dois cultivares de Cynodon dactylon Pers e o cultivar jamaicano de Cynodon nlemfuensis Vanderyst, principalmente para o nível mais baixo de nitrogênio. Valores mais elevados de recuperação do nitrogênio (60\%) foram encontrados por CARO-COSTA et al. (1960) para colonião comum nas mesmas doses utilizadas no trabalho anterior (448 quilogramas de nitrogênio por hectare) e atingindo $41,5 \%$ na dose de 896 quilogramas de nitrogênio por hectare anualmente. Neste trabalho encontraram-se recuperações para o capim-gordura variando de 32,0 a $13,2 \%$ de para as doses de 224 e 896 quilogramas de nitrogênio por hectare, respectivamente, quando avaliados aos 60 dias de crescimento. Esta recuperação aumentou para o gordura, quando o período de crescimento foi de 40 dias, principalmente para a menor dose de nitrogênio.

A importância da avaliação do nitrogênio recuperado com o aumento dos níveis de adubação, deve ser bem observado porque diversos resultados demonstram que as quantidades extraídas superam as adicionadas, como revelaram os resultados de ANDRADE et al. (1991) com variedades de Panicum maximum Jacq, para a dose mais baixa, o que indica a provável hipótese da degradação destas forrageiras sem reposição da fertilidade do solo. Estes resultados estão de acordo com os obtidos por BRUNET et al. (1988a) utilizando, anualmente, doses de 60 quilogramas de nitrogênio por hectare para Panicum maximum Jacq cultivar Likoni. MONTEIRO et al. (1980), trabalhando com capim-colonião não encontraram tendência a extrações mais elevadas para os 
tratamentos com adição de nitrogênio, o que possivelmente ocorreu devido à baixa produção de matéria seca, provavelmente influenciada pela maior quantidade de nitrogênio utilizado na adubação de final do período chuvoso e/ou pelo pequeno número de cortes. GHISI et al. (1989), comparando variedades de Panicum maximum Jacq, observaram que, para a dose anual de 50 quilogramas de nitrogênio por hectare, houve extração sempre superior a 200 quilogramas de nitrogênio no primeiro ano, o que deve ter influenciado a redução de produção dos anos subsequentes.

A influência de utilização do nitrogênio pela Brachiaria brizantha Stapf é alta como foi demonstrado no trabalho de ALVIM et al. (1990), a qual foi superior ao se adubar com nitrogênio, embora para a ausência de adubação nitrogenada tenha tido o pior desempenho entre as braquiárias avaliadas. Isto, também foi, verificado por SOTOMAYOR-RIOS et al. (1973), quando compararam dois acessos de Brachiaria brizantha Stapf, dentre dezesseis gramíneas, utilizando 470 quilogramas de nitrogênio por hectare anualmente, tendo obtido a maior produção para as brizanthas com o corte aos 60 dias de crescimento, o que não ocorreu quando a colheita foi realizada no melhor estágio desenvolvimento, o que foi confirmado por SOTOMAYOR-RIOS et al. (1976).

$\mathrm{O}$ efeito do nitrogênio sobre o desenvolvimento fisiológico da forragem foi destacado por CORSI (1975), assinalando que a sua utilização provoca o aumento da longevidade das folhas, como demonstraram CORSI et al. (1994), comparando as braquiarias Marandu, decumbens e humidícola, evidenciando uma maior taxa de elongação do Marandu, além de maior número de folhas em elongação.

PAERSE \& WILLIAN (1984) demonstraram que, ao aumentar o nível de nitrogênio de 0 para 132 quilogramas por hectare, a taxa de aparecimento de folhas por perfilho por semana aumentou de 0,52 para 0,76 e taxa de elongação de folha passou de 4,2 para $12,1 \mathrm{~mm} /$ perfilho/dia em azevém. Infelizmente estes resultados não estão diponíveis na literatura para forrageiras tropicais. 
A melhoria de valor nutritivo é também destacada devido ao aumento do $\mathrm{N}$-total, o qual é geralmente determinado nas análises bromatológicas e não deve ser assumida como proteína verdadeira (FERNANDES \& ROSSIELO, 1986). Deve-se isto às diversas formas que o nitrogênio pode ser encontrado na planta, determinadas por diversos fatores inerentes à planta e ao ambiente.

\subsection{Atividade da redutase do nitrato}

A absorção de formas nitrogenadas acarreta diferentes rotas de aproveitamento do nitrogênio pelas plantas. Assim, o nitrogênio nítrico, ao ser absorvido, necessita ser transformado a $\mathrm{NH}_{2}$, para ser incorporado em amidas (como ácido glutâmico) e formar, com esqueletos de carbono, aminoácidos livres que constituirão a base dos tecidos estruturais para o crescimento. Estudos têm demonstrado que essa assimilação é limitada no processo de redução a amônia sendo a redutase do nitrato a enzima-chave desse processo (RUFTY et al., 1986) para a incorporação até glutamato. A atividade da redutase do nitrato tem grande dependência de fluxos contínuos de nitrato para que se mantenha ativa, como foi demonstrado por BENDIX et al. (1982). Neste trabalho realizado com Paspalum notatum Flugge, em casa-de-vegetação utilizando-se solo, foi observado aumento da atividade da redutase do nitrato com o parcelamento em três aplicações de 30 miligramas de nitrogênio por quilograma de solo na forma de nitrato, em relação a única adubação de 90 miligramas de nitrogênio por quilograma de solo, comportamento que está de acordo com os resultados obtidos por HEIMER \& FILNER (1971), usando plantas de fumo. A confirmação desta dependência por fluxos contínuos de nitrato para ativação do sistema enzimático é relatada por SRIVASTAVA (1980) e LA HABA et al. (1988) devido ao aumento de síntese "de novo" da proteína.

O íon nitrato, após a absorção, pode ser estocado nos vacúolos do sistema radicular (HAGEMAM \& BELOW, 1990; TAIZ \& ZIEGER, 1991) ou 
ser translocado via xilema para a parte aérea, onde poderá ser armazenado ou reduzido (RUFTY et al., 1986; LAYZELL, 1990). O nitrato absorvido em elevadas quantidades pode ser armazenado nos vacúolos, se não for prontamente assimilado, formando o que se denomina "pool substrato". Resultados de estudos realizados com células isoladas ou protoplastos de várias espécies vegetais demonstram que 58 a $99 \%$ do nitrato total é estocado no vacúolo, evidenciando a menor proporção do "pool" citoplasmático ou indutor (OSCARSON et al., 1987). Essas elevadas quantidades armazenadas podem prejudicar o aumento linear da produção de matéria seca como demonstrado por FERNANDES \& FREIRE (1976), ao trabalharem com Brachiaria sp., indicando que aumentos no solo, acima ou em torno de 80 miligramas de nitrogênio por quilograma de solo na forma de nitrato, aproximam-se do valor máximo para a utilização eficiente de nitrogênio, nas condições do experimento. Neste mesmo trabalho não foi encontrada diferença para o teor proteico com o aumento do nitrato de 0 a 80 miligramas de nitrogênio por quilograma de solo, embora a participação percentual de $\mathrm{N}$-livre em relação ao $\mathrm{N}$-total tenha aumentado, o que está de acordo com os resultados obtidos por HAGEMAN \& FLESHER (1960), utilizando milho. Esses autores citaram que tal resultado pode ter sido alterado pelas condições ambientais, o que possivelmente reduziu a quantidade de esqueletos carbônicos. Entretanto, resultados para outras gramíneas e, principalmente tropicais, não foram encontrados na literatura.

O nível de irradiância é um fator que afeta a expressão da redutase do nitrato (YONEYAMA et al., 1987).

A redução do nitrato pode ocorrer nas folhas, raízes ou em ambas, variando com a espécie e taxa de absorção (NAMBIAR et al., 1988). Na maioria das espécies temperadas e sob baixas concentrações de nitrato no solo, a redução do nitrato ocorre preferencialmente nas raízes. Nessas espécies, a redução na parte aérea torna-se importante apenas quando a concentração externa de nitrato é muito alta. Em espécies tropicais e subtropicais, ao contrário, a redução 
do nitrato ocorre principalmente na parte aérea, independente da concentração externa desse íon (NAMBIAR et al., 1988).

FERNANDES \& FREIRE (1978), trabalhando com a Brachiaria $s p$., observaram que a atividade da redutase do nitrato foi positiva $\mathrm{e}$ significativamente correlacionada com o teor de nitrogênio proteico das folhas e bainhas $(r=0,97)$, o que não foi comprovado por experimento anterior dos mesmos autores.

Além do aumento da atividade da redutase do nitrato poder ocorrer por fluxos contínuos de nitrato, observa-se mesma tendência com a adição de baixas doses de amônio, o qual pode aumentar a síntese de proteína e da própria enzima (SRIVASTAVA, 1980), tal como foi demonstrado por FERNANDES \& FREIRE (1978). Este efeito foi bastante evidente sobre o aumento da atividade da redutase do nitrato em função da adição da baixa dose de nitrogênio na forma mais reduzida, parecendo indicar uma aceleração na síntese de compostos orgânicos com o aumento da atividade metabólica que acarreta na absorção mais rápida de nitrato. Este efeito poderia explicar a maior atividade do sistema redutase do nitrato como foi demonstrado por ZIELKER \& FILNER (1971). Quando a velocidade de absorção de nitrato é reduzida, o nível de atividade da enzima também o é, a despeito de altos níveis de nitrato nos tecidos.

\subsection{Utilização de formas nitrogenadas}

Diversos trabalhos tem sido conduzidos com o intuito de se obter a melhor proporção de nitrato/amônio. SRIVASTAVA (1980) e LEWIS et al. (1982) hipotetizaram sobre a razão ótima de nitrato/amônio que promove maior assimilação comparando-se a utilização de apenas uma das formas nitrogenadas. Neste sentido, SCHRADER et al. (1972) verificaram que plantas de milho cultivadas em solução nutritiva com amônio, na presença ou não de nitrato, 
acumulavam maior quantidade de $\mathrm{N}$-orgânico do que na presença exclusiva de nitrato. SILVEIRA (1981), objetivando determinar o efeito da proporção amônio/nitrato em plantas de capim-colonião cultivadas em solução nutritiva, observou aumento do peso da matéria seca de até $65 \%$, na medida em que se elevou essa relação.

SILVEIRA (1980) relatou que o nitrogênio na planta pode ser dividido em três grandes frações: $\mathrm{N}$-inorgânico $\left(\mathrm{NO}_{3}{ }^{-}\right.$e $\left.\mathrm{NH}_{4}{ }^{+}\right), \mathrm{N}$-alfa amino solúvel e $\mathrm{N}$-proteico. $\mathrm{O} \mathrm{N}$-alfa amino (aminoácidos, aminas e amidas) é a fração mais variável em função dos distúrbios nutricionais.

A fase intermediária da assimilação do nitrogênio, que constitui o $\mathrm{N}$-alfa amino, pode ser aumentada pelas reduções de iluminação e temperatura causando um acúmulo desta nos tecidos e, principalmente na parte aérea, podendo provocar redução na produção de matéria seca. Esta situação pode ser demonstrada pela correlação de - 0,978 entre $\mathrm{N}$-livre e produção de matéria seca no trabalho de BENDIX et al. (1982) com Paspalum notatum Flugge. Esses resultados estão de acordo com os apresentados por FERNANDES \& FREIRE (1976) com Bracharia sp. e ROSSIELO et al. (1981) com milho.

A aplicação de doses elevadas de nitrato de amônio resultou em uma taxa de sintese de proteína menor do que a taxa de acumulação de $\mathrm{N}$-amino, implicando numa elevada concentração desta fração em Dactilis glomerata e Festuca arundinacea (GLENN et al., 1985).

$\mathrm{O} \mathrm{N}$-solúvel tem quantidades reduzidas nos tecidos, entretanto quando ocorre deficiência de nitrogênio e na situação em que o nivel de nitrogênio supera o necessário para o crescimento, as formas solúveis começam a acumular-se nos tecidos (NOVOA \& LOOMIS, 1981)

Desta forma, em um primeiro passo, a perfeita compreensão do sistema enzimático e o aproveitamento de formas amídicas e amínicas são de fundamental importância, principalmente para plantas em que o sistema radicular não funcione como órgão armazenador, como foi demonstrado no trabalho de 
IMPITHUKSA \& BLUE (1985), no qual compararam as forrageiras Cynodon nlemfuensis Vanderyst, Digitaria decumbens Stent e Paspalum notatum Flugge e apenas na última espécie, as raízes e rizomas funcionaram como acumuladores destas formas.

O amônio não é acumulado em condições normais e, por ser tóxico em concentrações relativamente baixas, causa alterações metabólicas. Contudo, seu aumento pode ocorrer em condições de absorção excessiva ou pela falta de esqueletos carbônicos para sua incorporação (FERNANDES \& ROSSIELO, 1986).

Quando ocorre excesso de amônia nos tecidos, inicialmente acelera o processo usual de assimilação (via sintetase da glutamina / sintetase do glutamato). Persistindo o excesso, vias alternativas são ativadas (glutamina desidrogenase e asparagina sintetase). Desta forma, no caso de altos níveis de amônia, glutamina e asparagina tendem a acumular-se nos tecidos.

A utilização de várias fontes nitrogenadas pode provocar um desbalanço na absorção de ânions ou cátions (TISDALE et al., 1985). O uso da forma nítrica promove aumento da absorção de cálcio, potássio e magnésio para compensar a maior absorção de nitrogênio na forma aniônica, já que este, em valores absolutos é o mais absorvido. A absorção do amônio pode promover aumento de absorção de formas aniônicas. Por outro lado, este amônio pode promover um forte efeito competitivo sobre os cátions básicos, de tal forma que a concentração destes venha a ser menor em plantas dependentes de nitrogênio amoniacal do que do nítrico (ADAMS, 1981). A relação da absorção das formas de $\mathrm{N}$ com outros nutrientes é um fenômeno que, simplesmente, procura manter a eletroneutralidade dentro da planta.

MONTEIRO et al. (1994), trabalhando com solução nutritiva em sílica, sob omissão de macronutrientes para Brachiaria brizantha Stapf cv. Marandu, observaram que a omissão de cálcio resultou nos maiores valores de produção de matéria seca, número de perfilhos e altura de plantas. A solução que 
foi utilizada (SARRUGE, 1975) no experimento tinha apenas formas nítricas no tratamento completo, e na omissão de cálcio, o amônio contribui com $25 \%$ e o nitrato com $75 \%$ do total do nitrogênio suprido.

Algumas propostas ou até mesmo um conjunto delas pode explicar o observado, tal como a de TISDALE et al. (1985), de que a forma amoniacal é praticamente incorporada sem gasto de energia, além do já mencionado, que a utilização das duas fontes pode aumentar a produção de matéria seca. Outra proposta apresentada por LEYSHON et al. (1980), ao estudarem plantas de trigo nos primeiros estágios de desenvolvimento propuseram que o sistema enzimático não estava em pleno funcionamento e que a absorção de amônio poderia melhorar a produção de matéria seca. 


\section{MATERIAL E MÉTODOS}

Foram realizados dois experimentos em casa-de-vegetação do Departamento de Química da Escola Superior de Agricultura "Luiz de Queiroz", situada em Piracicaba, São Paulo $\left(22^{\circ} 42^{`} 31^{\prime \prime}\right.$ de latitude Sul e $47^{\circ} 38^{\prime} 01^{\prime \prime}$ de longitude Oeste).

\subsection{Primeiro experimento}

Este experimento buscou avaliar a atividade da redutase do nitrato, o desempenho produtivo e a composição de Panicum maximum Jacq cv. Tanzânia-1, Brachiaria brizantha Stapf cv. Marandu e Melinis minutiflora Beauv cultivados sob três níveis de nitrato na condição de casa-de-vegetação.

\subsubsection{Condições de instalação e condução do experimento}

A germinação das sementes foi feita em bandeja de alumínio contendo areia lavada em água corrente e posteriormente em água deionizada. O plantio foi realizado em uma época para cada espécie com a finalidade de igualar o crescimento inicial. Primeiro foi semeado o capim-gordura, dez dias após realizou-se a semeadura do capim-Tanzânia-1 e, finalmente, dezessete dias após a primeira semeadura foi semeado o capim-Marandu. Durante esta fase, foi realizada aplicação da solução de $\mathrm{KH}_{2} \mathrm{PO}_{4}(0,1 \mathrm{mM})$ para um desenvolvimento mais rápido das plântulas. Aos vinte e sete dias após a primeira semeadura, em 
03 de setembro de 1994, quinze plântulas de cada espécie foram transplantadas para os vasos de plástico contendo 5 quilogramas de sílica e um litro de cada solução, à $30 \%$ da concentração total, correspondente a cada tratamento. A solução diluída permaneceu nos vasos durante o dia e a noite, até o primeiro desbaste, com circulação três vezes por dia. O primeiro desbaste foi realizado aos sete dias após o transplantio, permanecendo apenas as 10 plantas mais uniformes em cada vaso. A partir deste primeiro desbaste a solução permaneceu nos vasos, somente durante o dia. Foi realizado o segundo desbaste dez dias após o transplantio, restando sete plantas. Finalmente, com vinte dias de crescimento após o transplantio foi realizado o último desbaste quando então permaneceram cinco plantas por vaso. A solução foi trocada, já com concentração total, aos 11; $19 ; 25 ; 34 ; 39$ e 47 dias após o transplantio.

\subsubsection{Tratamentos e delineamento experimental}

Foi empregado o delineamento de blocos ao acaso, num esquema fatorial, com três repetições perfazendo um total de 27 vasos. Os fatores foram três níveis de nitrato e três espécies. Foram utilizadas concentrações de 28; $112 \mathrm{e}$ $210 \mathrm{mg} . \mathrm{l}^{-1}$ de nitrogênio nítrico, com a finalidade de avaliar o melhor nível para resposta da atividade da redutase do nitrato, em casa-de-vegetação.

\subsubsection{Soluções nutritivas nos tratamentos}

As soluções foram preparadas a partir da solução de SARRUGE (1975) com as modificações para os niveis de nitrogênio e para as soluções estoque então necessárias. A composição da solução em cada nível de nitrogênio é apresentada na Tabela 1. 
TABELA 1 - Composição química das soluções nutritivas (ml. $1^{-1}$ ) para níveis de nitrogênio do primeiro experimento.

\begin{tabular}{|c|c|c|c|c|}
\hline \multirow{2}{*}{$\begin{array}{l}\text { Soluções } \\
\text { Estoque }\end{array}$} & \multirow[t]{2}{*}{ Concéntração } & \multicolumn{3}{|c|}{ Soluções mg de $\mathrm{NO}_{3}^{-} 1^{-1}$} \\
\hline & & 28 & 112 & 210 \\
\hline Acetato $\mathrm{Ca}$ & $0,5 \mathrm{M}$ & 8,0 & 4,0 & \\
\hline $\mathrm{KH}_{2} \mathrm{PO}_{4}$ & $\mathrm{M}$ & 1,0 & 1,0 & 1,0 \\
\hline $\mathrm{MgSO}_{4}$ & $\mathrm{M}$ & 2,0 & 1,0 & 2,0 \\
\hline $\mathrm{Ca}\left(\mathrm{NO}_{3}\right)_{2}$ & $\mathrm{M}$ & 1,0 & 3,0 & 5,0 \\
\hline $\mathrm{KCl}$ & $\mathrm{M}$ & 5,0 & 3,0 & \\
\hline $\mathrm{Mg}\left(\mathrm{NO}_{3}\right)_{2}$ & $\mathrm{M}$ & & 1,0 & \\
\hline $\mathrm{K}_{2} \mathrm{SO}_{4}$ & $0,5 \mathrm{M}$ & & 2,0 & \\
\hline $\mathrm{KNO}_{3}$ & $\mathrm{M}$ & & & 5,0 \\
\hline Micro - Fe & $*$ & 1,0 & 1,0 & 1,0 \\
\hline Fe EDTA & $* *$ & 1,0 & 1,0 & 1,0 \\
\hline
\end{tabular}

* A solução de micronutrientes teve a seguinte composição (g/l): $\mathrm{H}_{3} \mathrm{BO}_{3}$ - 2,86; $\mathrm{MnCl}_{2} \cdot 4 \mathrm{H}_{2} \mathrm{O}-1,81 ; \mathrm{ZnCl}_{2}-0,10 ; \mathrm{CuCl}_{2}-0,04$ e $_{2} \mathrm{MoO}_{4} \cdot \mathrm{H}_{2} \mathrm{O}-0,02$.

** Dissolveram-se 26,1g de EDTA dissódico em $286 \mathrm{ml}$ de $\mathrm{NaOH} \mathrm{N}$, misturando-se com $24,0 \mathrm{~g}$ de $\mathrm{FeSO}_{4} \cdot 7 \mathrm{H}_{2} \mathrm{O}$, arejando-se por uma noite e completando-se a 1 litro de água deionizada.

\subsubsection{Coleta do material vegetal}

Aos 55 dias (29/10/94) após o início do uso da solução nutritiva a parte aérea foi cortada rente à coroa das plantas e subdividida em folhas novas, folhas velhas (senescentes + mortas) e colmos + bainhas. As raizes foram lavadas em água corrente, para retirada da sílica e, em seguida, com água deionizada. Todo o material colhido foi posto a secar em estufa de circulação forçada de ar, a $65^{\circ} \mathrm{C}$, por 72 horas. 


\subsection{Segundo experimento}

Buscou-se nesse experimento realizar a avaliação da atividade da redutase do nitrato, do desempenho produtivo, da partição das frações nitrogenadas e composição de Panicum maximum Jacq, Brachiaria brizantha Stapf e Melinis minutiflora Beauv sob proporções de nitrato e amônio na solução nutritiva.

\subsubsection{Condições de instalação e condução do experimento}

As sementes das gramíneas foram postas a germinar em bandeja de alumínio contendo areia lavada em água corrente e, posteriormente, em água deionizada. A semeadura foi realizada em uma data para cada espécie, com a finalidade de igualar o crescimento inicial. O capim-gordura foi semeado primeiro, dez dias após realizou-se a semeadura do capim-Tanzânia-1 e finalmente, dezessete dias após a do capim-gordura foi foi realizada a semeadura do capim-Marandu. Durante esta fase foi realizada uma aplicação de solução de $\mathrm{KH}_{2} \mathrm{PO}_{4}(0,1 \mathrm{mM})$ para as plântulas. Em 17 de setembro de 1994, ou seja vinte sete dias após a primeira semeadura, quinze plântulas foram transplantadas para os vasos de plástico contendo $5 \mathrm{~kg}$ de sílica e um litro de solução, a $30 \%$ da concentração total, correspondente a cada tratamento. A solução diluída permaneceu até o desbaste, durante o dia e a noite com circulação três vezes por dia. O desbaste foi realizado aos sete dias após o transplantio, permanecendo apenas as dez plantas mais uniformes. A partir deste desbaste, a solução permaneceu nos vasos somente durante o dia.

A solução a $30 \%$ da concentração total foi trocada no $11^{0}$ dia após o transplantio. As trocas de solução completa foram realizadas no $27^{0}, 39^{\circ}$, $49^{\circ}$ e $61^{\varrho}$ dias após o transplantio. 


\subsubsection{Tratamentos e delineamento experimental}

Utilizou-se o delineamento de blocos ao acaso num esquema em fatorial $5 \times 3$, com três repetições, perfazendo um total de 45 vasos. Os fatores foram cinco proporções de nitrato/amônio e três espécies. Foram utilizadas as soluções contendo diversas proporções de nitrato e amônio (100\%/0\%; 75\%/25\%; $50 \% / 50 \% ; 25 \% / 75 \%$ e $75 \% / 25 \%$ sem $\mathrm{Ca}$ ) com as concentrações usadas na solução de SARRUGE (1975), para o nível de maior resposta da atividade da redutase do nitrato obtido em 3.1 , que foi de $210 \mathrm{mg} . \mathrm{l}^{-1}$.

\subsubsection{Soluções nutritivas nos tratamentos}

As soluções foram calculadas a partir da solução de SARRUGE (1975) e são apresentadas na Tabela 2. 
TABELA 2 - Composição química das soluções nutritivas $\left(\mathrm{ml} . \mathrm{I}^{-1}\right.$ ) para proporções de nitrato/amônio, no segundo experimento.

\begin{tabular}{|c|c|c|c|c|c|c|}
\hline \multirow{2}{*}{$\begin{array}{l}\text { Soluções } \\
\text { Estoque }\end{array}$} & \multirow{2}{*}{$\begin{array}{c}\text { Concen- } \\
\text { tração }\end{array}$} & \multicolumn{5}{|c|}{ Soluções $\left(\% \mathrm{NO}_{3}{ }^{-} \mathrm{NH}_{4}^{+}\right)$} \\
\hline & & $100 / 0$ & $75 / 25$ & $75 / 25-\mathrm{Ca}$ & $50 / 50$ & $25 / 75$ \\
\hline $\mathrm{KH}_{2} \mathrm{PO}_{4}$ & $\mathrm{M}$ & 1 & & 1 & & 1 \\
\hline $\mathrm{KNO}_{3}$ & $\mathrm{M}$ & 5 & 2 & 1 & 5 & 1,75 \\
\hline $\mathrm{Ca}\left(\mathrm{NO}_{3}\right)_{2}$ & $\mathrm{M}$ & 5 & 2 & & & \\
\hline $\mathrm{MgSO}_{4}$ & $\mathrm{M}$ & 2 & & & 2 & 1 \\
\hline $\mathrm{K}_{2} \mathrm{SO}_{4}$ & $0,5 \mathrm{M}$ & & 4 & 4 & & 2 \\
\hline $\mathrm{Mg}\left(\mathrm{NO}_{3}\right)_{2}$ & $\mathrm{M}$ & & 2 & 2 & & 1 \\
\hline Acetato $\mathrm{Ca}$ & $0,5 \mathrm{M}$ & & 6 & & 10 & 10 \\
\hline Citrato $\mathrm{NH}_{4}$ & $0,33 \mathrm{M}$ & & 1,5 & 0,5 & 5 & 11,25 \\
\hline $\mathrm{NH}_{4} \mathrm{NO}_{3}$ & $\mathrm{M}$ & & 1,25 & 3,25 & 2,5 & \\
\hline $\mathrm{NH}_{4} \mathrm{H}_{2} \mathrm{PO}_{4}$ & $\mathrm{M}$ & & 1 & & & \\
\hline $\mathrm{NaNO}_{3}$ & M & & & 3 & & \\
\hline $\mathrm{KCl}$ & $\mathrm{M}$ & & & & & 1,25 \\
\hline Micro -Fe & $*$ & 1 & 1 & 1 & 1 & 1 \\
\hline Fe EDTA & $* *$ & 1 & 1 & 1 & 1 & 1 \\
\hline
\end{tabular}

* A solução de micronutrientes teve a seguinte composição $(\mathrm{g} / \mathrm{l}): \mathrm{H}_{3} \mathrm{BO}_{3}$ 2,$86 ; \mathrm{MnCl}_{2} \cdot 4 \mathrm{H}_{2} \mathrm{O}-1,81 ; \mathrm{ZnCl}_{2}-0,10 ; \mathrm{CuCl}_{2}-0,04$ e $_{2} \mathrm{MoO}_{4} \cdot \mathrm{H}_{2} \mathrm{O}-0,02$.

** Dissolveram-se 26,1g de EDTA dissódico em $286 \mathrm{ml}$ de $\mathrm{NaOH} \mathrm{N}$, misturando-se com $24,0 \mathrm{~g}$ de $\mathrm{FeSO}_{4} \cdot 7 \mathrm{H}_{2} \mathrm{O}$, arejando-se por uma noite e completando-se a 1 litro de água deionizada.

\subsubsection{Coleta do material vegetal}

Aos 71 dias do início da utilização das soluções nutritivas, procedeu-se o corte das plantas, empregando-se metodologia idêntica à descrita para o primeiro experimento. 


\subsection{Determinações no material vegetal}

\subsubsection{Produção de matéria seca}

Em ambos os experimentos foi determinada a produção de matéria seca de cada componente da parte aérea, de toda parte aérea e das raízes ao final do período experimental, após a secagem do material em estufa.

\subsubsection{Concentração de nitrogênio}

No material vegetal proveniente dos experimentos foi realizada a avaliação do teor de $\mathrm{N}$-total nas frações da parte aérea e nas raizes, conforme metodologia descrita por SARRUGE \& HAAG (1974).

\subsubsection{Composição mineral}

A determinação dos teores de fósforo, potássio, cálcio, magnésio e enxofre nas frações da parte aérea e raízes foi efetuado no material vegetal colhido no segundo experimento, conforme metodologia descrita por SARRUGE \& HAAG (1974).

\subsubsection{Atividade da redutase do nitrato}

A atividade da redutase do nitrato foi realizada tomando-se amostras do limbo da segunda folha completamente expandida de cada planta (no sentido da ponta para base).

No primeiro experimento, o limbo foliar foi colhido aos 22 dias após o início do mesmo, sendo a coleta desse material vegetal realizada às 8:00, 9:00 e 10:00 horas para cada bloco experimental, respectivamente. 
Para o segundo experimento, a determinação foi realizada 46 dias após o transplantio para dois blocos e aos 47 dias para o terceiro bloco experimental. As avaliações foram feitas às 9:30 e 10:00 horas do primeiro dia e às 10:00 horas do segundo dia.

O método para determinação da atividade da redutase do nitrato foi o descrito por MULDER et al. (1959). A determinação iniciou com a incubação, por duas horas, de $200 \mathrm{mg}$ de material verde cortado, no meio de $\mathrm{KNO}_{3}$ em tampão fosfato. Foi retirado $1,0 \mathrm{ml}$ do meio de incubação e o $\mathrm{NO}_{2}$ presente foi determinado por adição de $1,0 \mathrm{ml}$ de ácido sulfanílico e $\mathrm{HCl}$ à $20 \%$ para paralizar a reação, seguido da adição de $1 \mathrm{ml}$ de alfa naftilamina, para formar a cor ao reagir com o $\mathrm{NO}_{2}$. A leitura foi feita em colorímetro a $540 \mathrm{~nm}$ utilizandose reta padrão de nitrito.

\subsubsection{Concentração de nitrogênio nítrico e amoniacal}

Foram efetuadas essas determinações no material vegetal colhido em ambos os experimentos. A determinação de amônio foi realizada como descrito por TEDESCO et al. (1985), utilizando-se 0,1 g do material seco das diversas partes das plantas em todos os tratamentos e destilado após adição de $0,2 \mathrm{~g}$ de $\mathrm{MgO}$ calcinado. O nitrato foi determinado logo em sequência, no mesmo tubo utilizado para destilação do amônio, adicionando-se 0,2 g de "liga de Devarda". As frações de amônio e nitrato foram obtidas através da titulação com ácido sulfúrico a $0,001 \mathrm{M}$, após serem recolhidas em indicadores com ácido bórico. 


\section{RESULTADOS E DISCUSSÃO}

\subsection{Primeiro experimento}

\subsubsection{Efeito dos níveis de nitrato sobre o número de perfilhos}

A avaliação do número de perfilhos ao final do experimento mostrou aumento significativo $(\mathrm{P}<0,05)$ para as espécies e para os níveis de nitrato $(\mathrm{P}<0,05)$, tendo sido o capim-gordura a espécie com maior número a partir do nível intermediário de nitrato, seguida do capim-Marandu e com menor número o capim-Tanzânia-1 (Figura 1). Houve interação significativa $(\mathrm{P}<0,05)$ entre os níveis e as espécies e através do desdobramento dela pode-se verificar que, no mais baixo nível de nitrato, todas as espécies apresentaram o mesmo comportamento. Estes resultados são inerentes a cada espécie e são devidos a estruturas morfológicas e hábitos de crescimento, como destacaram OTERO (1961) e BOGDAN (1977).

Para as três espécies as equações têm coeficientes de determinação iguais ou próximos à unidade. Para os capins gordura e Marandu a regressão significativa foi quadrática, evidenciando que estas duas espécies não tem tendência a aumentar com a mesma intensidade o número de perfilhos por vaso, que o capim-Tanzânia-1, o qual mostrou tendência de aumentar a quantidade de perfilhos além da dose de $210 \mathrm{mg} . \mathrm{l}^{-1}$. Entretanto, deve-se ressaltar que o capim-gordura apresentou a maior taxa de perfilhamento seguido dos capins Marandu e Tanzânia-1. 


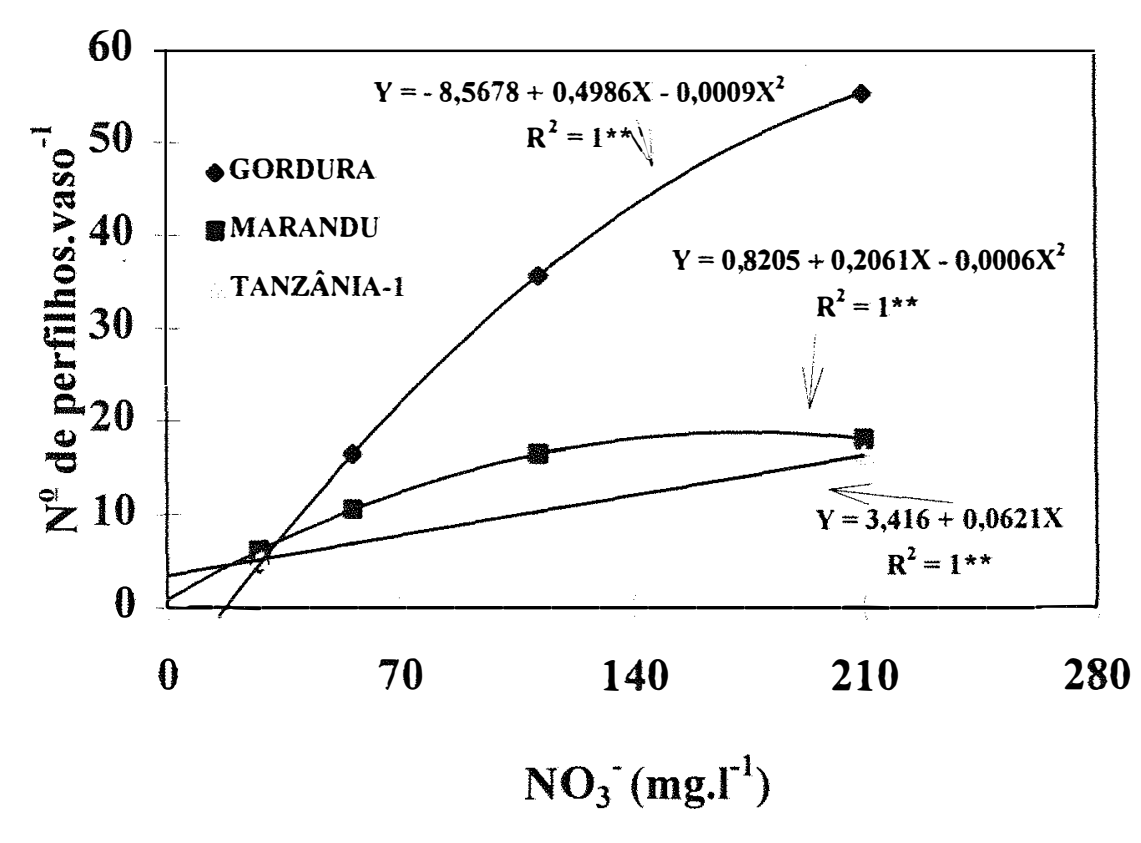

- $\mathrm{CV}=8,20 \%$

- DMS Tukey a $5 \%$ (média para espécies e para níveis) $=2,08$

- DMS Tukey a 5\% (interação entre as espécies) =3,60

Figura 1. Número de perfilhos por vaso nos capins gordura, Marandu e Tanzânia1 sob níveis de nitrato em solução nutritiva.

\subsubsection{Efeito dos níveis de nitrato sobre a produção de matéria seca}

A produção de matéria seca da parte aérea nas três espécies sofreu incrementos significativos $(\mathrm{P}<0,01)$ em função dos níveis de nitrato utilizados para todas as espécies (Figura 2), o que evidencia a essencialidade do nitrogênio para o aumento da produção de forragem (NOVOA, 1981). Contudo, na média dos níveis de nitrato para cada espécie, estas apresentaram comportamentos diferentes, tendo o capim-Tanzânia-1 a maior produção, a qual diferiu estatisticamente $(\mathrm{P}>0,05)$ dos capins Marandu e gordura. Também 
ocorreu diferença significativa $(\mathrm{P}>0,05)$ entre os capins Marandu e gordura, sendo que o primeiro foi superior.

Os resultados da produção de matéria seca da parte aérea entre as espécies, dentro de cada nível de nitrato, apresentaram comportamentos diferentes. $\mathrm{Na}$ solução nutritiva com $28 \mathrm{mg} / 1$ de $\mathrm{NO}_{3}^{-}$as três forrageiras não diferiram significativamente $(\mathrm{P}>0,05)$, contudo para os tratamentos com maiores concentrações de nitrato houve diferença entre os capins $(\mathrm{P}<0,05)$. Na solução com $112 \mathrm{mg}^{-1} \mathrm{l}^{-1} \mathrm{de}_{3}^{-}$, o capim-Tanzânia-1 foi superior ao gordura, e o capimMarundu não diferiu dos demais, entretanto para a solução com maior concentração de nitrato o capim-Tanzânia-1 foi superior ao capim-Marandu, e esse superior ao capim-gordura.

Respostas semelhantes foram encontradas para Panicum maximum Jacq por CARO-COSTAS et al. (1960), OLSEN (1972), GHISI et al. (1989) e ANDRADE et al. (1991). Para Brachiaria brizantha Stapf respostas semelhantes à adubação nitrogenada foram encontradas por ALVIM et al. (1990). Comparando-se o Panicum e a Brachiaria, EMBRAPA (1985) reportou valores de Panicum superiores aos de brizantha, ao empregar niveis de nitrogênio.

$\mathrm{O}$ aumento linear da produção de matéria seca da parte aérea evidencia que as três forrageiras tem potencial para responder a níveis mais elevados, nas mesmas condições do experimento. Torna-se necessário usar doses de nitrato mais elevadas com a finalidade de se obter o ponto de maior produção de matéria seca, o qual não foi atingido para os primeiros níveis de nitrogênio utilizados, como obtiveram CARO-COSTAS et al. (1960) utilizando capimgordura. Entretanto, deve-se ressaltar que a inclinação da curva de regressão foi menor para o capim-gordura em relação às outras duas forrageiras. 


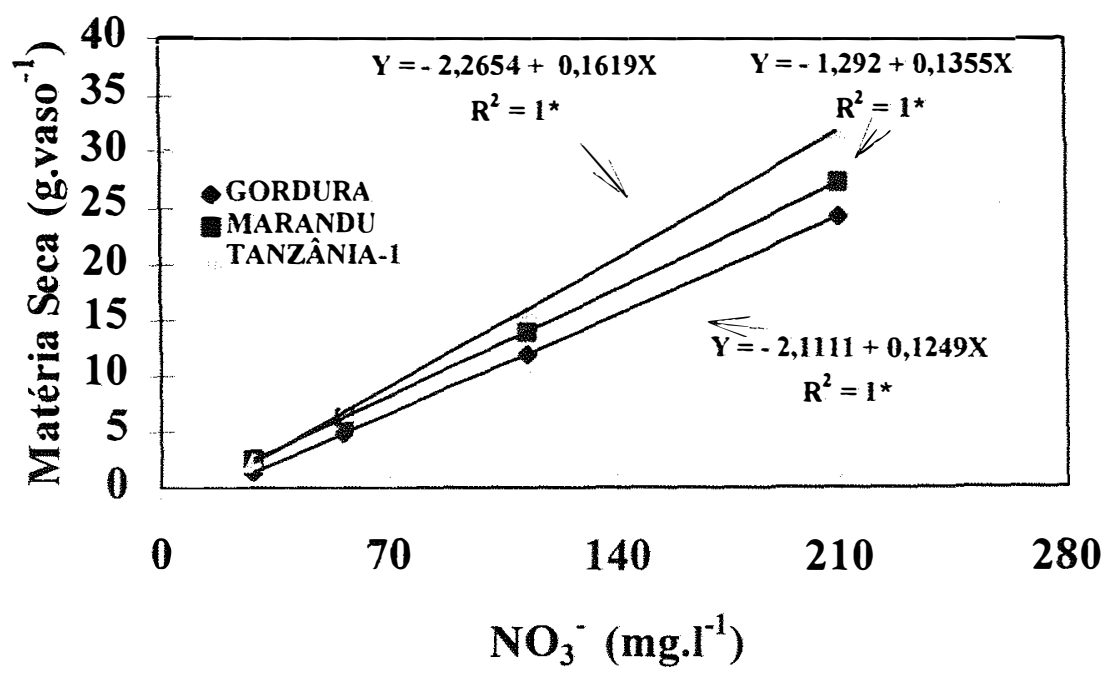

$-\mathrm{CV}=8,8 \%$

- DMS Tukey a 5\% (média das espécies e dos níveis) $=1,55$

- DMS Tukey a 5\% (interação entre fatores) $=2,69$

Figura 2. Produção de matéria seca da parte aérea $\left(\right.$ g.vaso $^{-1}$ ) nos capins gordura, Marandu e Tanzânia-1 sob níveis de nitrato em solução nutritiva.

O rendimento de matéria seca das folhas novas, em função dos níveis de nitrato, apresentou comportamento idêntico ao da produção de matéria seca da parte aérea, com diferença significativa $(P<0,01)$ para os niveis estudados e para as espécies, como mostra a figura 3.

A participação das folhas novas na parte aérea, para os níveis médio e alto de nitrogênio na solução, foi sempre menor para o capim-gordura, com 25,5 e 24,4\%, respectivamente quando comparado aos capins Marandu e Tanzânia-1 que apresentaram respectivamente 41,9 e 39,1, e 39,9 e 37,7\% para os níveis médio e alto. Estes resultados mostram uma menor quantidade de material fotossinteticamente mais ativo no capim-gordura, sugerindo uma hipótese para o seu desempenho inferior aos outros dois capins testados, tal como obtido por VICENTE-CHANDLER (1972). 


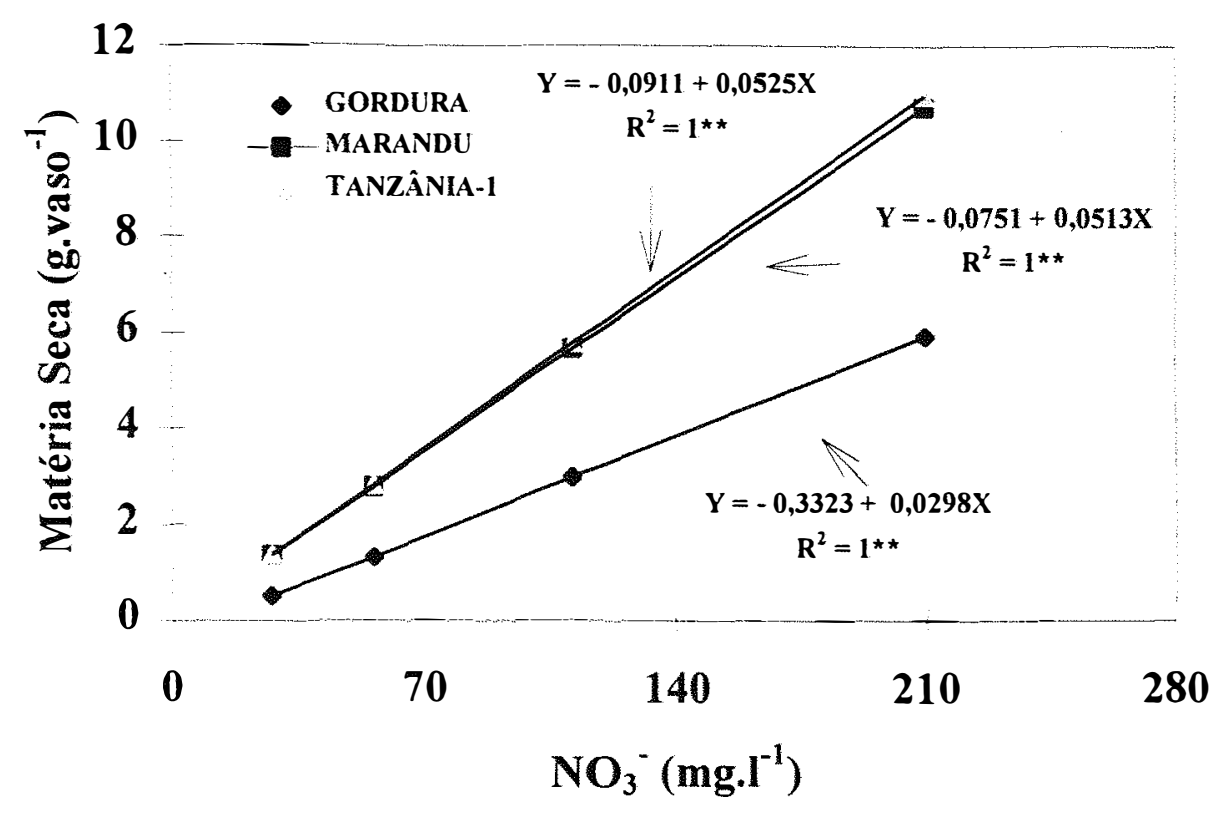

$-\mathrm{CV}=14,1 \%$

- DMS Tukey a $5 \%$ (média das espécies e dos níveis) $=1,48$

- DMS Tukey a 5\% (interação entre fatores) $=0,86$

Figura 3. Produção de matéria seca das folhas novas (g.vaso ${ }^{-1}$ ) dos capins gordura, Marandu e Tanzânia-1 sob níveis de nitrato em solução nutritiva.

A produção de matéria seca das folhas velhas apresentou diferença significativa $(\mathrm{P}<0,05)$ para os fatores níveis de nitrato e para as espécies (Figura 4). O capim-Tanzânia-1 foi obteve maiores produções que as

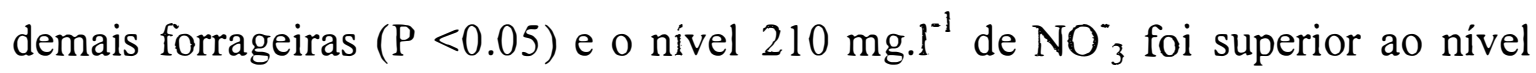
intermediário, o qual superou o menor nível. Houve efeito para a interação de espécies com os níveis de nitrato para o capim-Tanzânia-1 sendo superior aos demais no maior nível de nitrato, evidenciando a alta capacidade de crescimento, taxa de elongação e senescência deste material genético (CARO-COSTAS et al., 1960), quando comparado a outras gramíneas, como demonstrou EMBRAPA (1985). 
As curvas de rendimento de matéria seca das folhas novas e velhas demonstram que estes dois extratos da planta podem apresentar maiores valores com o aumento da dose de nitrogênio de nitrogênio em solução nutritiva.

A produção de matéria seca dos colmos mais bainhas foi diferente $(\mathrm{P}<0,05)$ para os níveis. Entretanto não foram detectadas diferenças significativas $(P>0,05)$ entre as espécies e nem significância para a interação das espécies e níveis de nitrato ( Figura 5). A igualdade entre as espécies para esta variável demonstra a grande proporção de colmos e bainhas do capim-gordura, provavelmente devido ao seu elevado perfilhamento como ressaltaram CAROCOSTAS et al. (1960) e VICENTE-CHANDLER (1972).

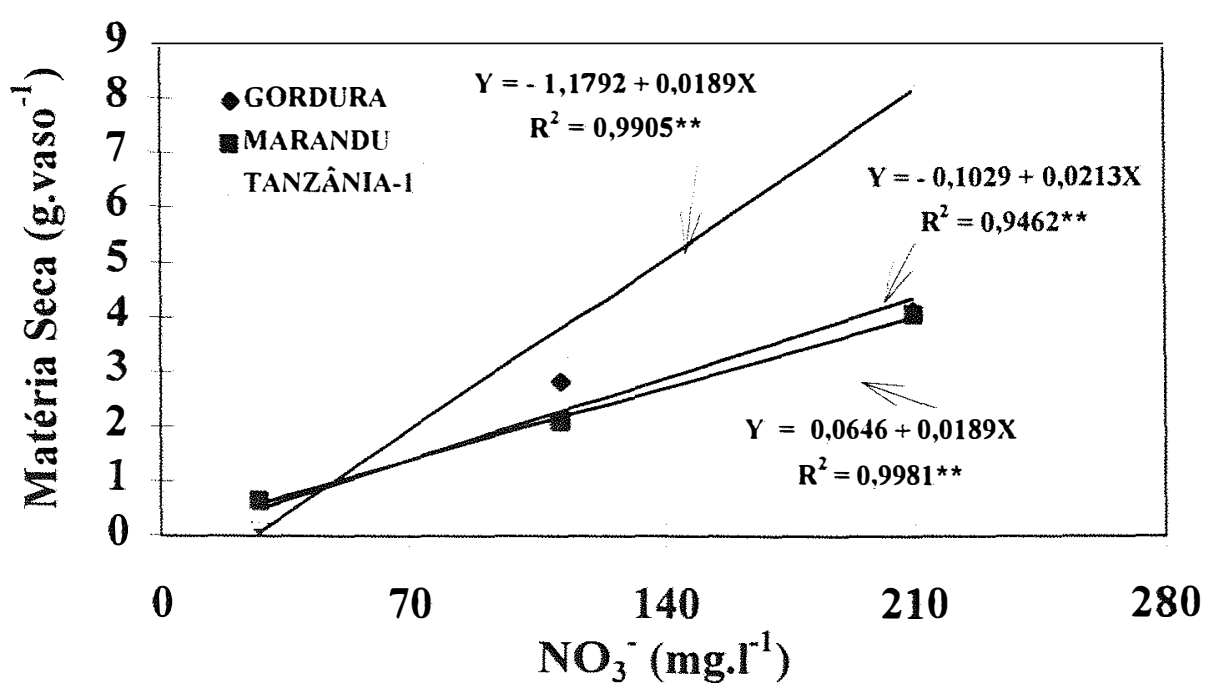

- $\mathrm{CV}=33,2 \%$

- DMS Tukey a 5\% (média das espécies e dos níveis) $=2,02$

- DMS Tukey a 5\% (interação entre fatores) $=1,16$

Figura 4. Produção de matéria seca das folhas velhas (g.vaso ${ }^{-1}$ ) nos capins gordura, Marandu e Tanzânia-1 sob níveis de nitrato em solução nutritiva. 
O rendimento de matéria seca das raízes foi diferente $(\mathrm{P}<0,05)$ para os níveis de nitrato utilizados, como demonstrado na figura 6 .

Não houve diferença significativa $(\mathrm{P}>0,05)$ entre as espécies, para a média dos níveis de nitrato. Entretanto, considerando as espécies dentro de cada nível de nitrato foi possível verificar para o nível mais elevado de nitrato, superioridade $(\mathrm{P}<0,05)$ dos capins Tanzânia-1 e Marandu sobre o capimgordura. Esta não elevação no peso das raízes do capim-gordura até o nível mais elevado, fica evidente quando se observam as curvas de crescimento, nas quais para os capins Marandu e Tanzânia-1, não foi verificada redução de matéria seca com o aumento da dose de nitrogênio, enquanto que para o gordura seria obtida redução do acúmulo de material seco para a dose calculada de $240 \mathrm{mg} \cdot \mathrm{l}^{-1}$.

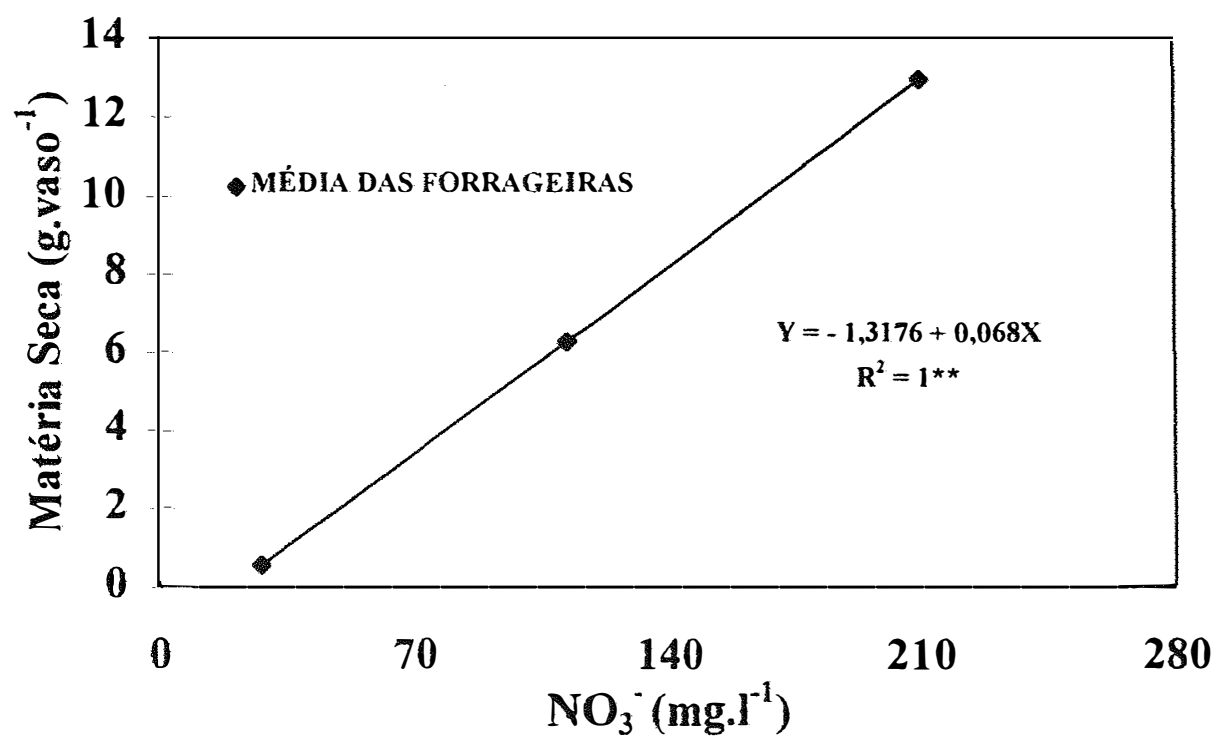

- $\mathrm{CV}=16,8 \%$

- DMS Tukey a 5\% (média das espécies e dos níveis) $=1,35$

Figura 5. Produção de matéria seca dos colmos + bainhas (g.vaso ${ }^{-1}$ ) dos capins gordura, Marandu e Tanzânia-1 sob níveis de nitrato em solução nutritiva. 


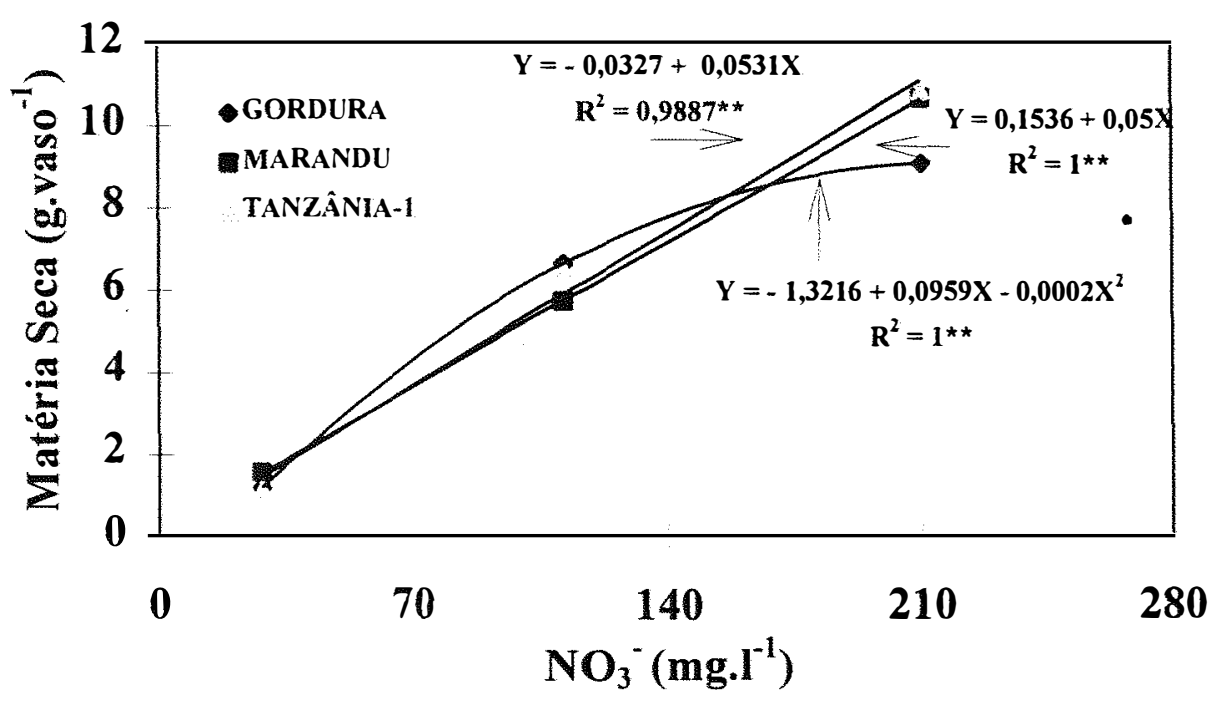

- $\mathrm{CV}=10,2 \%$

- DMS Tukey a 5\% (média das espécies e dos níveis) $=1,28$

- DMS Tukey a $5 \%$ (interação entre fatores) $=0,74$

Figura 6. Produção de matéria seca das raízes $\left(\right.$ g.vaso $^{-1}$ ) dos capins gordura, Marandu e Tanzânia-1 sob níveis de nitrato em solução nutritiva.

\subsubsection{Efeito dos níveis de nitrato sobre a concentração de nitrogênio nos tecidos vegetais}

A concentração de nitrogênio da parte aérea diferiu significativamente $(P<0,05)$ entre os níveis de nitrato na solução, com a obtenção do maior teor no mais elevado nível de nitrogênio (Figura 7). Para as espécies não se detectou diferença signifïcativa $(P>0,05)$ na concentração média de nitrogênio. Contudo, ocorreu interação significativa $(P<0,01)$ entre espécies e níveis de nitrato. $O$ desdobramento dessa interação mostrou as três espécies apresentando concentrações semelhantes para o menor nível de nitrato, enquanto que para o nível médio, o capim-Marandu teve a maior concentração e as outras duas gramíneas não diferiram entre si. Isto pode ser interpretado como tendo 
ocorrido o efeito de diluição (JARREL \& BEVERLEY, 1981) para o capimTanzânia-1, devido ao seu maior crescimento, e o capim-gordura teria mostrado menor habilidade para utilização do nitrogênio, o que confirma as informações de CARO-COSTAS et al. (1960) e CARVALHO \& SARAIVA (1987). No nível mais elevado de nitrato as três forrageiras apresentaram iguais concentrações de nitrogênio $(P>0,05)$.

As concentrações de nitrogênio na matéria seca da parte aérea, para todas as espécies estudadas foram sempre inferiores aos resultados apresentados na literatura. O capim-gordura, para este estudo, obteve no menor nível de nitrato valores superiores aos obtidos por CARVALHO \& SARAIVA (1987), na ausência de adubação nitrogenada em um Latossolo VermelhoAmarelo. Contudo, para o nível de adubação de 50 quilogramas de nitrogênio por hectare por ano a concentração de nitrogênio foi semelhante à obtida no menor nível de nitrato do presente experimento. Os aumentos das doses de nitrato provocaram elevações significativas $(P<0,05)$ na concentração de nitrogênio desta forrageira, somente no nível mais elevado, a qual é inferior aos valores encontrados por CARO-COSTAS et al. (1960) e CARVALHO \& SARAIVA (1987) e superior aos valores obtidos por GOMIDE (1966). É possível que os resultados encontrados para o capim-gordura tenham sido inferiores aos de CARVALHO \& SARAIVA (1987) devido ao grande período de crescimento no presente experimento durante a primavera e sob elevadas temperaturas observadas na casa-de-vegetação, adiantando o desenvolvimento fenológico.

Para o capim-Marandu as concentrações de nitrogênio obtidas foram crescentes e significativamente diferentes do menor para o maior nível de nitrato na solução, com tendência a valores mais elevados para doses superiores a $210 \mathrm{mg}$ de $\mathrm{NO}_{3}^{-} \cdot 1^{-1}$. As concentrações de nitrogênio nesse capim são inferiores às encontradas por COWARD-LORD et al. (1974) e BOTREL et al. (1990). Entretanto, valores inferiores aos verificados nesse experimento foram 
encontrados, com essa braquiária, após 60 dias de crescimento, por COWARDLORD et al. (1974).

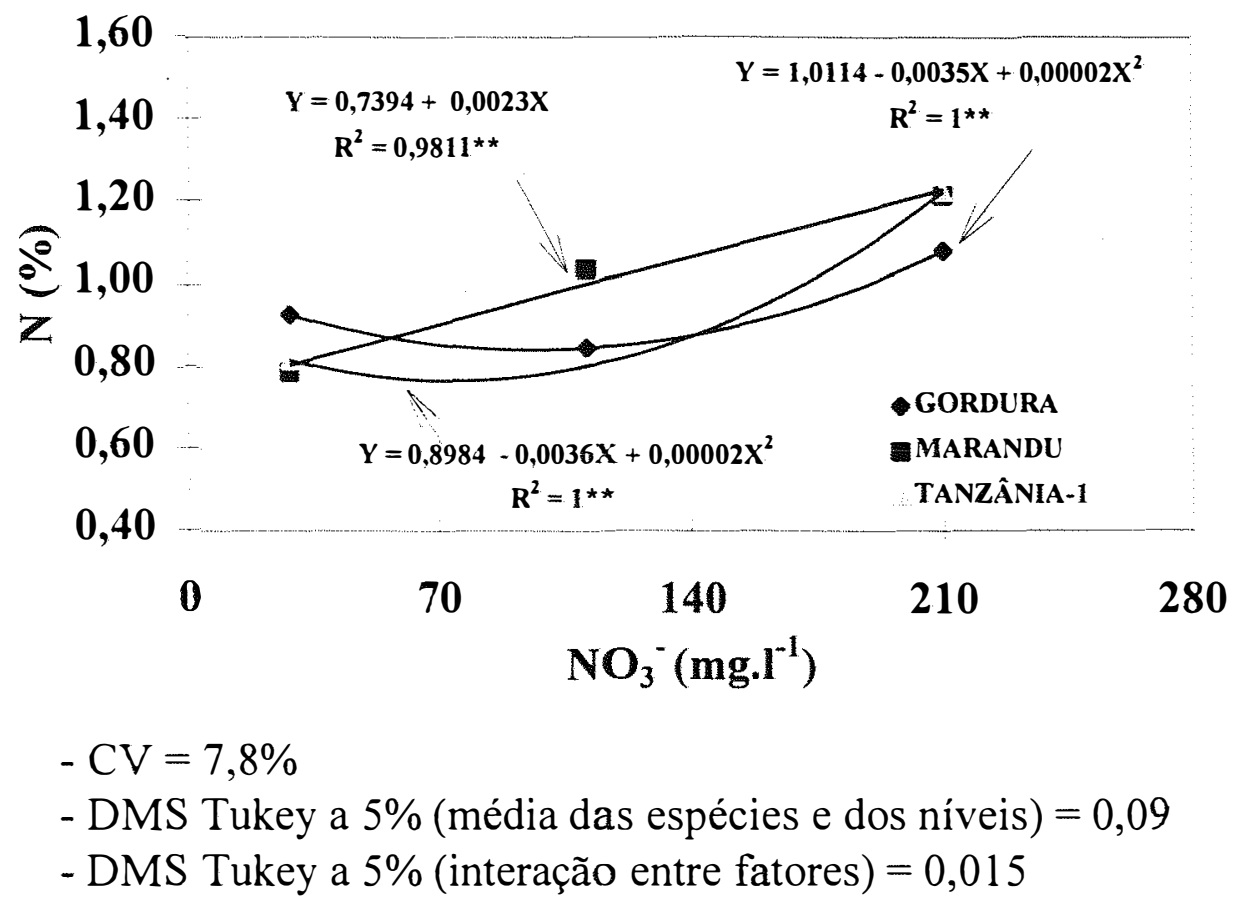

Figura 7 . Concentração de nitrogênio na matéria seca da parte aérea dos capins gordura, Marandu e Tanzânia-1 sob níveis de nitrato em solução nutritiva.

O capim-Tanzânia-1 apresentou diferença significativa $(\mathrm{P}<0,05)$ na concentração de nitrogênio na parte aérea, entre o maior e os menores níveis de nitrato. Esses resultados equivalem aos obtidos por BRUNET et al. (1988b) no nível mais elevado de adubação com nitrogênio para o período chuvoso. Entretanto para o período de estiagem os valores deste experimento são menores que aqueles.

As concentrações de nitrogênio para as folhas novas, apresentadas na figura 8, são superiores aos valores encontrados para as folhas velhas, que por sua vez são superiores aos encontrados nos colmos + bainhas, 
apresentados nas figuras 9 e 10, respectivamente. Este fato corrobora a informação de que é este um nutriente muito móvel na planta (MALAVOLTA, 1980 e MENGEL \& KIRKBY, 1987) .

Para a concentração de nitrogênio nas folhas novas, não houve diferença entre as forrageiras estudadas, com aumentos lineares do menor para o maior nível de nitrato. Os valores obtidos para esta variável não mostraram diferença significativa $(P>0,05)$ para os dois níveis mais baixos de nitrato, tendo sido o nível mais elevado superior aos demais. O capim-gordura evidenciou maior capacidade de translocar nitrogênio para os órgãos de maior metabolismo do que os outros dois capins testados, embora tenham sido estatisticamente iguais $(\mathrm{P}<.0,05)$.

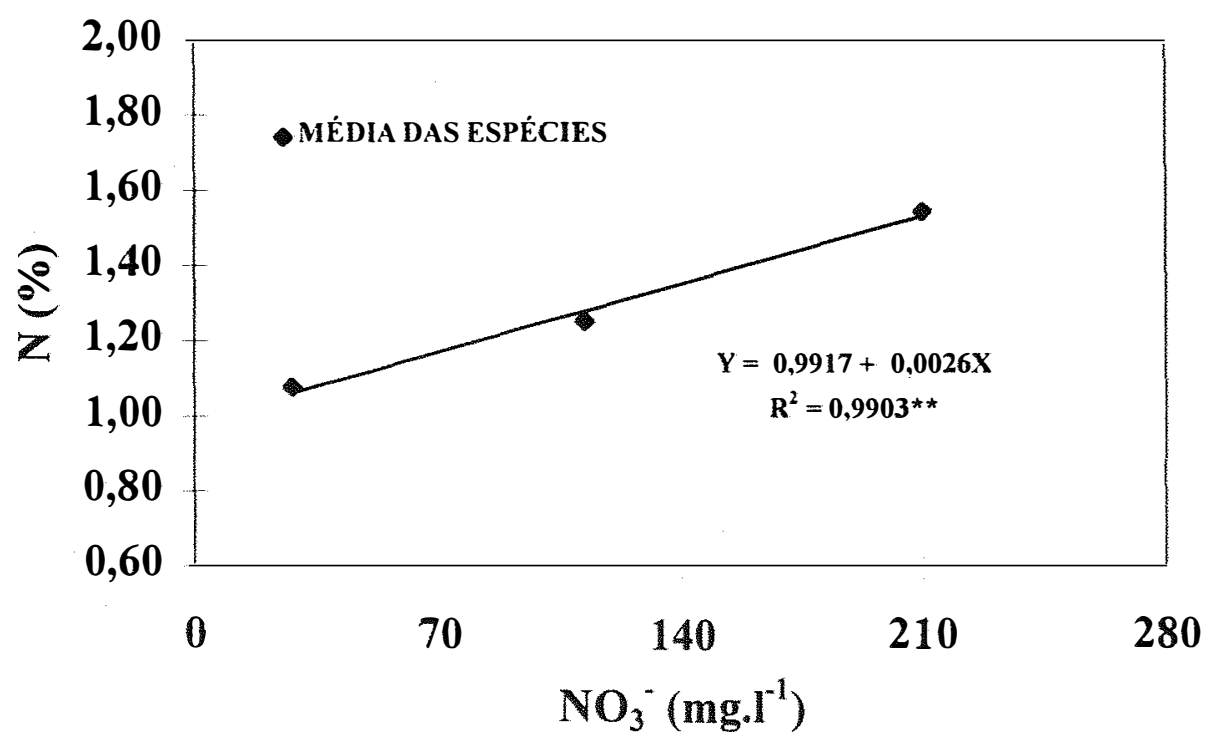

$-\mathrm{CV}=15,3 \%$

- DMS Tukey a 5\% (média das espécies e dos níveis) $=0,21$

Figura 8. Concentração de nitrogênio na matéria seca das folhas novas dos capins gordura, Marandu e Tanzânia-1 sob níveis de nitrato. 
A concentração de nitrogênio nas folhas velhas teve o mesmo comportamento apresentado para a matéria seca da parte aérea, com aumentos significativos $(\mathrm{P}<0,05)$ do menor para o maior nível de nitrato na solução nutritiva. $\mathrm{Na}$ comparação entre as espécies, os capins gordura e Marandu apresentaram teores de nitrogênio total nas folhas velhas significativamente superiores aos encontrados no capim-Tanzânia-1. O teor de nitrogênio das folhas velhas variou no capim-gordura, parecendo ter sofrido efeito de diluição na concentração intermediária de nitrato e acúmulo para as doses extremas. O capimMarandu teve maior concentração calculada de nitrogênio na dose de $187,5 \mathrm{mg}$ de $\mathrm{NO}_{3}{ }^{-} \cdot l^{-1}$. Provavelmente em função dos valores mais baixos para essa variável no capim-Tanzânia-1, observou-se aumento linear para a concentração de nitrogênio com a elevação da concentração de nitrato na solução.

O teor de nitrogênio total nos colmos e bainhas para a média dos três capins apresentou diferença significativa $(P<0,05)$ entre o maior e os dois menores níveis de nitrato na solução (Figura 10). Entretanto, não houve diferença entre as espécies $(P>0,05)$.

$\mathrm{O}$ efeito da interação entre espécies e níveis de nitrato foi significativo $(\mathrm{P}<0,05)$. Os capins Tanzânia-1 e Marandu tiveram as concentrações, nos maiores níveis superiores a do menor nível. O capim-gordura apresentou a menor concentração no nível intermediário, que foi inferior $(\mathrm{P}<$ $0,05)$ ao maior nível de nitrato, entretanto o nível $28 \mathrm{mg} \mathrm{de} \mathrm{NO}_{3}^{-} .1^{-1}$ foi igual aos demais, evidenciando novamente o efeito de diluição para esta forrageira. No menor nível de nitrato, o capim-gordura foi superior as demais forrageiras, as quais não diferiram entre si. Entretanto, para os dois maiores níveis de nitrato o capim-Marandu obteve concentrações superiores às do capim-Tanzânia-1, e o capim-gordura foi igual aos demais. 


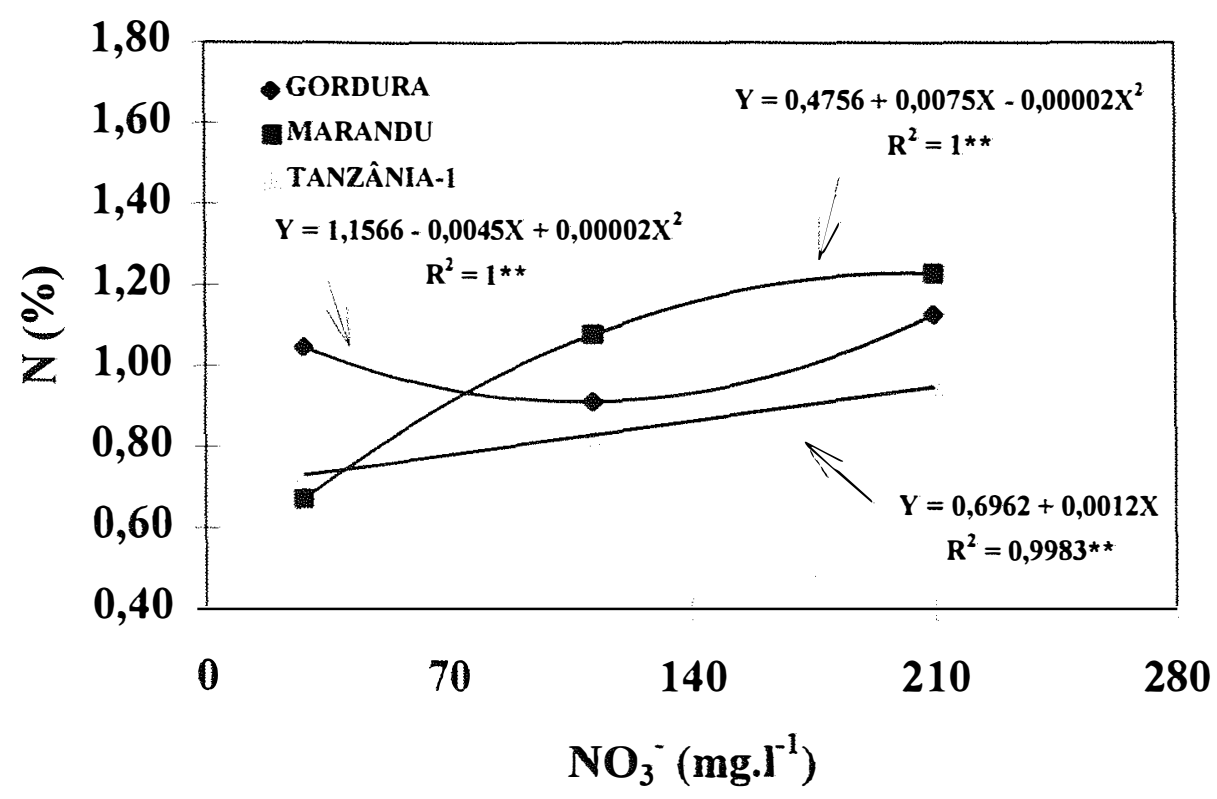

- C.V. $=10,0 \%$

- DMS Tukey a $5 \%$ (média das espécies e dos níveis) $=0,12$

- DMS Tukey a $5 \%$ (interação entre fatores) $=0.20$

Figura 9. Concentração de nitrogênio na matéria seca das folhas velhas nos capins gordura, Marandu e Tanzânia-1 sob níveis de nitrato em solução nutritiva.

A concentração de nitrogênio nas raízes apresentou valores médios inferiores aos das folhas novas e semelhante aos de folhas velhas e da parte aérea. Ocorreu o mesmo comportamento apresentado no nitrogênio da parte aérea, com significância $(\mathrm{P}<0,05)$ para a diferença entre o maior nível de nitrato na solução e os dois menores, como ilustrado na figura 11. Os teores de nitrogênio nessa fração da parte aérea do capim-Tanzânia-1 foram superiores aos do capimgordura e não deferiram do capim-Marandu.

O teor de nitrogênio nas raízes do capim-Tanzânia-1, no maior nível de nitrato na solução está abaixo daquele obtido por FRANÇA \& HAAG (1985), da mesma forma que o capim-Marandu apresentou valores inferiores aos obtidos por MONTEIRO et al. (1994). 


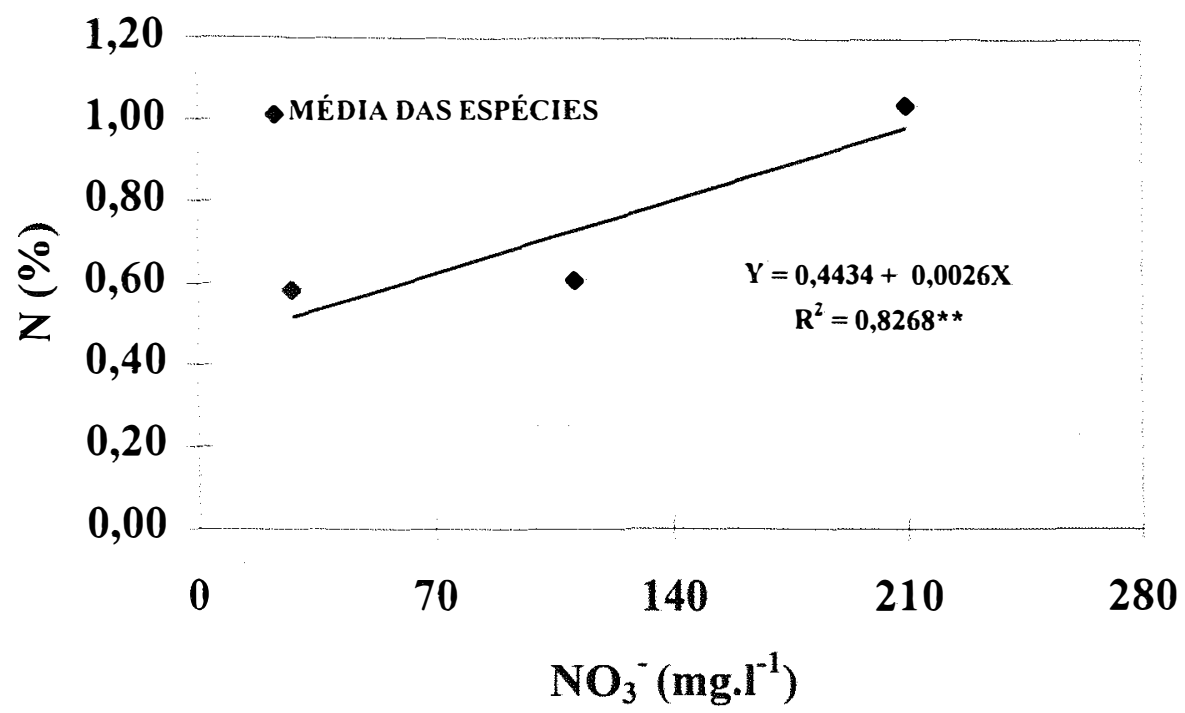

- C.V. $=24,4 \%$

- DMS Tukey a 5\% (média das espécies e dos níveis) $=0,22$

Figura 10. Concentração de nitrogênio na matéria seca de colmos + bainhas nos capins gordura, Marandu e Tanzânia-1 sob níveis de nitrato em solução nutritiva.

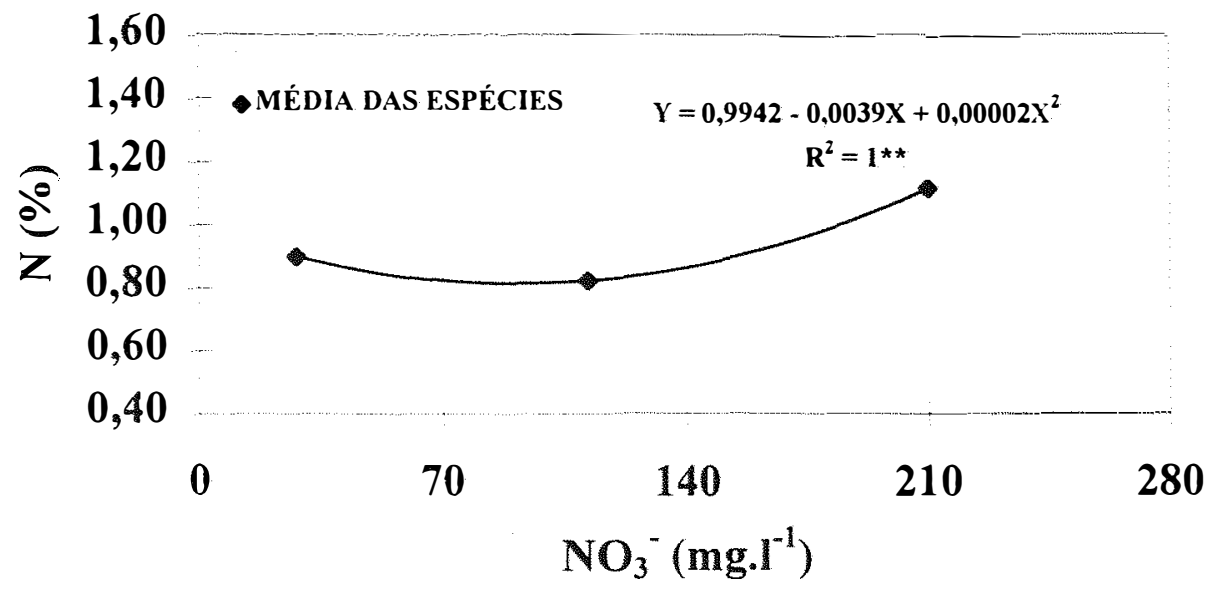

- C.V. $=11,2 \%$

- DMS Tukey a 5\% (média das espécies e dos níveis) $=0,13$

Figura 11. Concentração de nitrogênio na matéria seca das raízes dos capins gordura, Marandu e Tanzânia- 1 sob níveis de nitrato. 


\subsubsection{Efeito dos níveis de nitrato sobre a concentração de amônio nos tecidos vegetais}

A concentração de amônio na matéria seca da parte aérea foi afetada pelos níveis de nitrato $(\mathrm{P}<0,05)$ e não foi diferente entre as espécies $(\mathrm{P}>0,05)$. A concentração de amônio foi maior $(\mathrm{P}<0,05)$ para o nível $210 \mathrm{mg} / 1 \mathrm{de} \mathrm{NO}_{3}^{-}$, e igual entre os demais níveis (Figura 12).

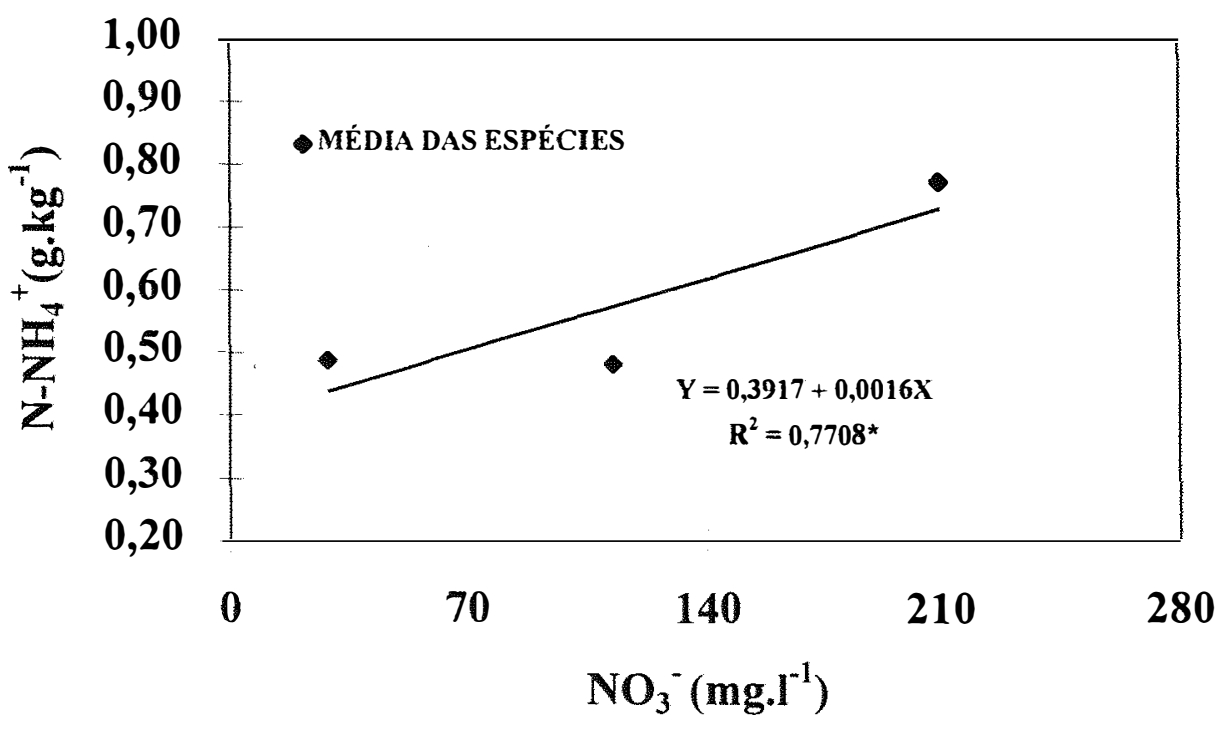

- C.V. $=16,31 \%$

- DMS Tukey a 5\% (média das espécies e dos níveis) $=0,12$

- DMS Tukey a 5\% (interação entre fatores) $=0,20$

Figura 12. Concentração de $\mathrm{N}-\mathrm{NH}_{4}{ }^{+}\left(\mathrm{g}\right.$ de N$\left.\cdot \mathrm{kg}^{-1}\right)$ da matéria seca da parte aérea nos capins gordura, Marandu e Tanzânia-1 sob níveis de nitrato em solução nutritiva.

A interação entre os fatores foi significativa $(P<0,05)$ para a concentração de amônio na parte aérea. Para o capim-gordura, foram obtidas as maiores concentrações nos níveis mais baixos, as quais foram diferentes do maior 
nível. Contudo, para os capins Marandu e Tanzânia-1 o maior nível foi superior aos demais e estes iguais entre si. A significância da interação entre espécies e os níveis de nitrato, só ocorreu no maior nível de nitrato, com superioridade do capim-Marandu sobre os demais.

Não foi possível encontrar na literatura resultados para essas espécies, a fim de se possa comparar com os obtidos no presente estudo. Entretanto FERNANDES \& FREIRE (1976) também obtiveram, para Brachiaria sp., concentrações maiores nos níveis mais elevados de nitrato e sempre superiores aos determinados nesse experimento. Os valores obtidos por CAUSIN et al. (1992) para plantas de trigo são bem menores do que os obtidos nesse estudo.

As concentrações de amônio nas folhas novas (Figura 13) foram inferiores às obtidas nas folhas velhas, superiores às obtidas em colmos e bainhas, e apresentaram diferenças significativas $(\mathrm{P}>0,05)$ entre as espécies, com os capins gordura e Tanzânia-1 superiores ao Marandu. Houve diferença entre os níveis de nitrato nas folhas novas $(\mathrm{P}<0.05)$. O nível intermediário teve a maior concentração, que foi superior a dos demais níveis. Este comportamento só não foi observado para o capim-Tanzânia-1, que apresentou a maior concentração ( $\mathrm{P}<$ $0,05)$ no nível de $210 \mathrm{mg}$ de $\mathrm{NO}_{3}^{-} \cdot l^{-1}$, além de uma pequena redução na concentração ao se elevar a dose de nitrato do primeiro para o segundo nível.

Através do desdobramento da interação entre espécie e níveis de nitrato foi possível verificar que o capim-gordura teve teor de amônio nas folhas novas significativamente superior ao capim-Marandu em todos os níveis, e com relação ao capim-Tanzânia- 1 foi superior, igual e menor, respectivamente nos níveis 112,28 e $210 \mathrm{mg} \mathrm{de} \mathrm{NO}_{3} \cdot 1^{-1}$, e esta última forrageira foi superior ao capimMarandu, apenas para o maior nível de nitrato. Os capins gordura e Marandu apresentaram maiores concentrações calculadas de amônio, respectivamente nas doses 124 e $112 \mathrm{mg}$ de $\mathrm{NO}_{3}^{-} \cdot 1^{-1}$. 
As concentrações de amônio nas folhas velhas foram superiores às das demais partes que compõem a parte aérea das plantas, apresentando valores significativamente $(P<0,01)$ mais elevados para o maior do que nos outros dois níveis de nitrato estudados, como mostrado na figura 14. Entretanto, não houve diferença entre as espécies para esta característica $(P>0,05)$.

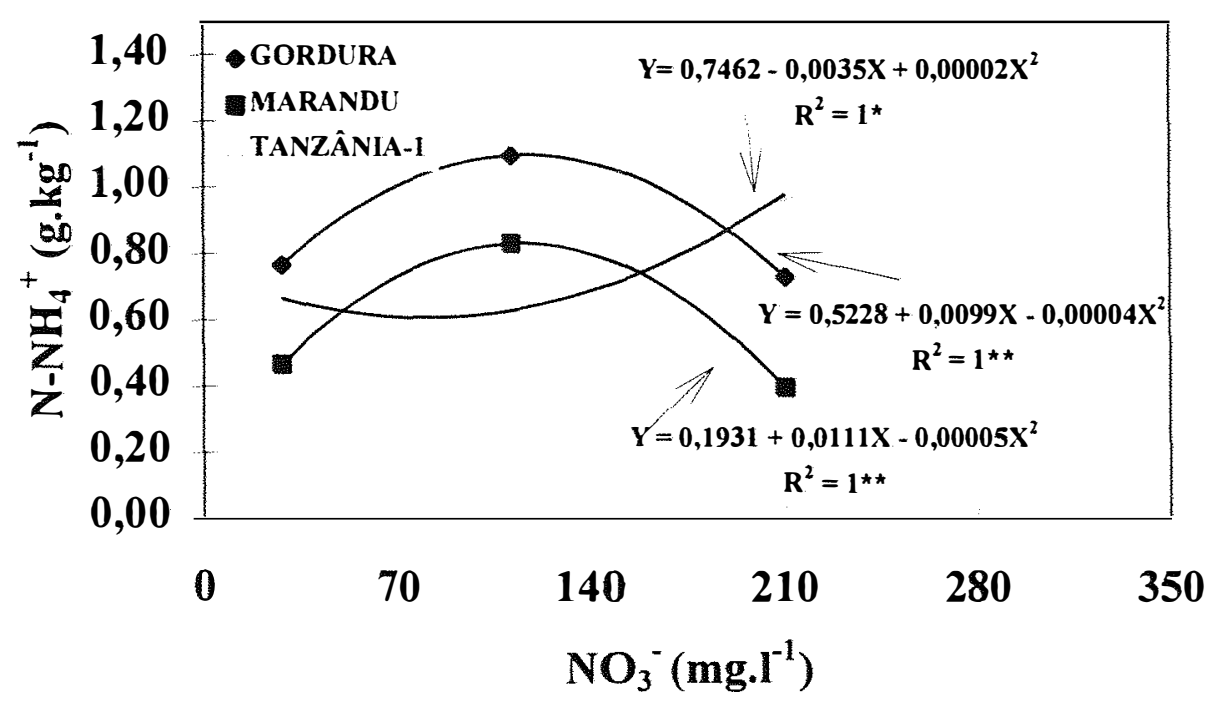

- C.V. $=15,3 \%$

- DMS Tukey a 5\% (média das espécies e dos níveis) $=0,13$

- DMS Tukey a 5\% (interação entre fatores) $=0,24$

Figura 13. Concentração de $\mathrm{N}-\mathrm{NH}_{4}{ }^{+}\left(\mathrm{g}\right.$ de N$\left.\cdot \mathrm{kg}^{-1}\right)$ da matéria seca das folhas novas nos capins gordura, Marandu e Tanzânia-1 sob níveis de nitrato em solução nutritiva.

A porcentagem de amônio para colmos + bainhas foi estatisticamente igual na média dos três níveis de nitrato (Figura 15). Por sua vez, essa concentração também não variou significativamente entre as espécies estudadas. Com o desdobramento da interação entre espécies e níveis de nitrato pode-se verificar que, somente no nível $210 \mathrm{mg}$ de $\mathrm{NO}_{3}^{-} \cdot 1^{-1}$ houve diferença 
significativa $(\mathrm{P}<0,05)$ entre as espécies, com o capim-gordura tendo teor de amônio inferior às outras duas gramíneas. O capim-gordura teve maior concentração de amônio nos colmos + bainhas na dose calculada de $104 \mathrm{mg}$ de $\mathrm{NO}_{3}^{-} \cdot l^{-1}$, enquanto que para os capins Marandu e Tanzânia-l os valores obedeceram a um aumento linear, com a elevação da dose de nitrato, que foi maior para o capim-Marandu.

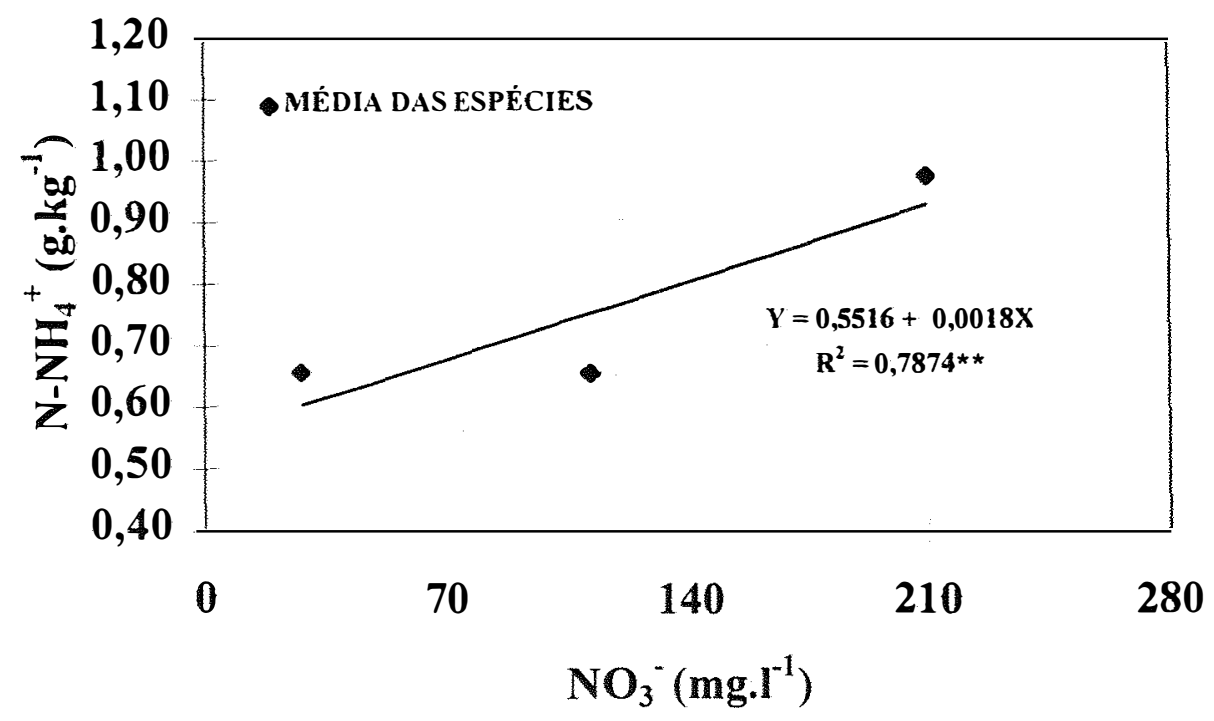

- C.V. $=22,9 \%$

- DMS Tukey a 5\% (média das espécies e dos níveis) $=0,21$

Figura 14. Concentração de $\mathrm{N}-\mathrm{NH}_{4}{ }^{+}\left(\mathrm{g}\right.$ de N.kg${ }^{-1}$ ) na matéria seca das folhas velhas dos capins gordura, Marandu e Tanzânia-1 sob níveis de nitrato em solução nutritiva.

A concentração de amônio nas raizes das três gramíneas sob os níveis de nitrato na solução está representada na figura 16 . O valor médio nesta variável foi superior ao da parte aérea, o que concorda com resultado obtido por LEWIS et al. (1982), para cevada. Não foram obtidas significâncias nas análises de regressão para quantidade de amônio nas raizes. 


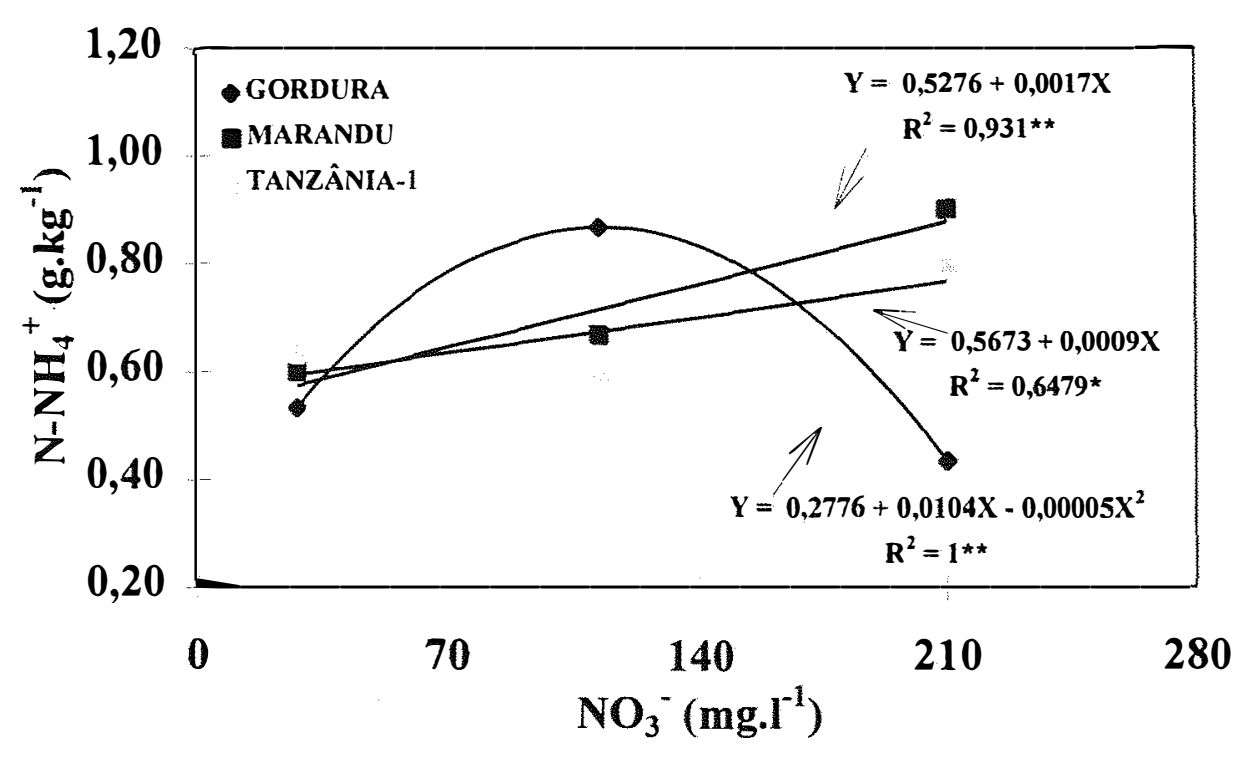

- C.V. $=19,39 \%$

- DMS Tukey a $5 \%$ (média das espécies e dos níveis) $=0,16$

- DMS Tukey a 5\% (interação entre fatores) $=0,27$

Figura 15. Concentração de $\mathrm{N}-\mathrm{NH}_{4}{ }^{+}\left(\mathrm{g}\right.$ de N$\left.\cdot \mathrm{kg}^{-1}\right)$ da matéria seca dos colmos + bainhas nos capins gordura, Marandu e Tanzânia-1 sob níveis de nitrato em solução nutritiva.

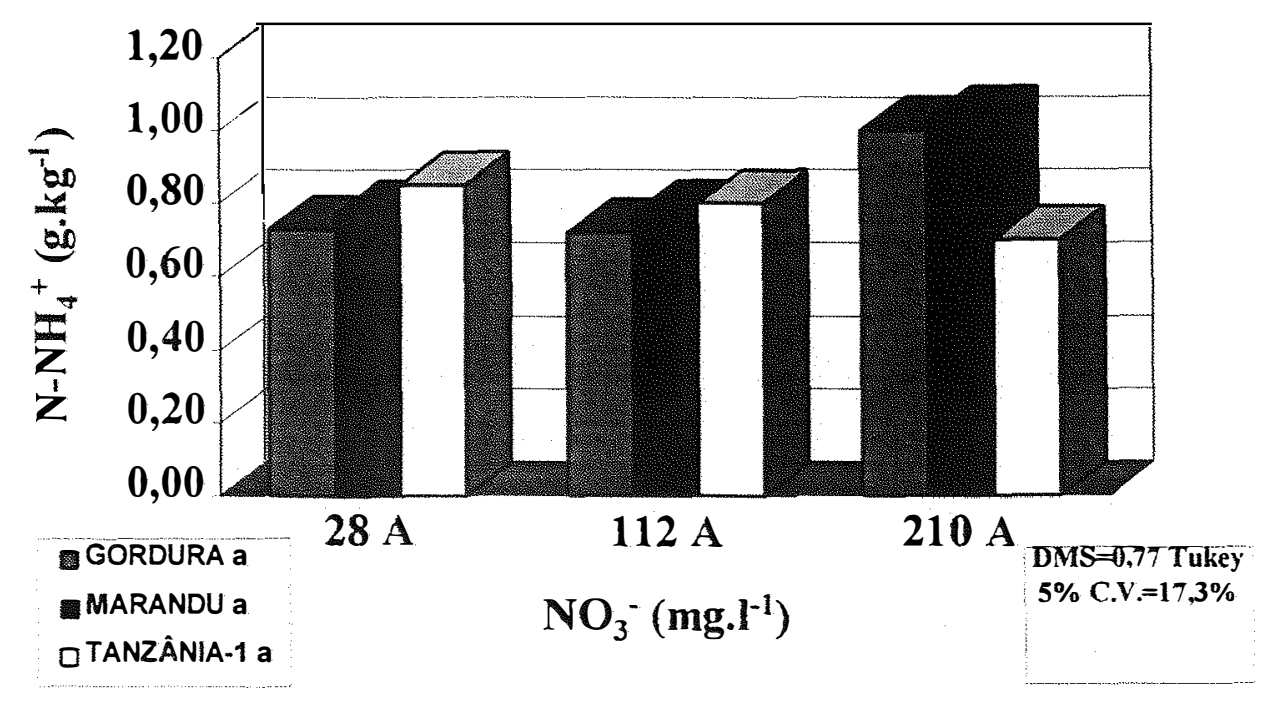

- Valores seguidos das mesmas letras maiúsculas não diferem entre si, respectivamente para níveis e espécies.

Figura 16. Concentração de $\mathrm{N}-\mathrm{NH}_{4}{ }^{+}$(g de N. $\mathrm{kg}^{-1}$ ) na matéria seca das raízes dos capins gordura, Marandu e Tanzânia-1 sob níveis de nitrato em solução nutritiva. 


\subsubsection{Efeito dos níveis de nitrato sobre a concentração de nitrato nos tecidos vegetais}

A concentração de nitrato na parte aérea das gramíneas estudadas foi influenciada pelo nível de nitrato na solução nutritiva, apresentando diferença significativa $(\mathrm{P}<0,05)$ entre o nível $28 \mathrm{mg}$ de $\mathrm{NO}_{3}{ }^{-} 1^{-1}$ e os maiores níveis. Houve diferença significativa $(P<0,05)$ entre as três espécies forrageiras para esse teor de nitrato, com o capim-Marandu acumulando quantidades inferiores as das outras forrageiras. Contudo, na maior dose de nitrato na solução o capimTanzânia-1 apresentou a maior concentração de nitrato $(P<0,01)$ em relação as demais forrageiras.

Os valores obtidos neste trabalho foram sempre inferiores à faixa de 0,25 - 0,31\% de nitrato na matéria seca, conforme indicado por SZODFRIDT \& VARGA (1989) como concentração crítica para ocorrência de toxicidade para animais.

O capim-Tanzânia-1 apresentou concentração de nitrato 7 a 10 vezes menor que os obtidos por QUEIROZ-FILHO et al. (1982) com Panicum maximum Jacq cv. Gatton. Contudo teores semelhantes de nitrato foram obtidos por OLSEN (1972), ao utilizar doses de nitrato até 448 quilogramas por hectare ano.

Resultados sobre níveis de nitrato na parte aérea da Brachiaria brizantha Stapf não foram obtidos na literatura consultada, o qual foi máximo para a dose de $122,5 \mathrm{mg}$ de $\mathrm{NO}_{3} \cdot 1^{-1}$. Contudo, os resultados do presente trabalho foram ligeiramente inferiores aos valores obtidos por FERNANDES \& FREIRE (1978) e pouco superiores aos reportados por FERNANDES \& FREIRE (1976), ambos com Brachiaria sp.

O capim-gordura apresentou a maior concentração de nitrato na dose de $112 \mathrm{mg}$ de $\mathrm{NO}_{3} \cdot 1^{-1}$, com uma redução acentuada na dose mais elevada, indicando um possível melhor aproveitamento de nitrato. 


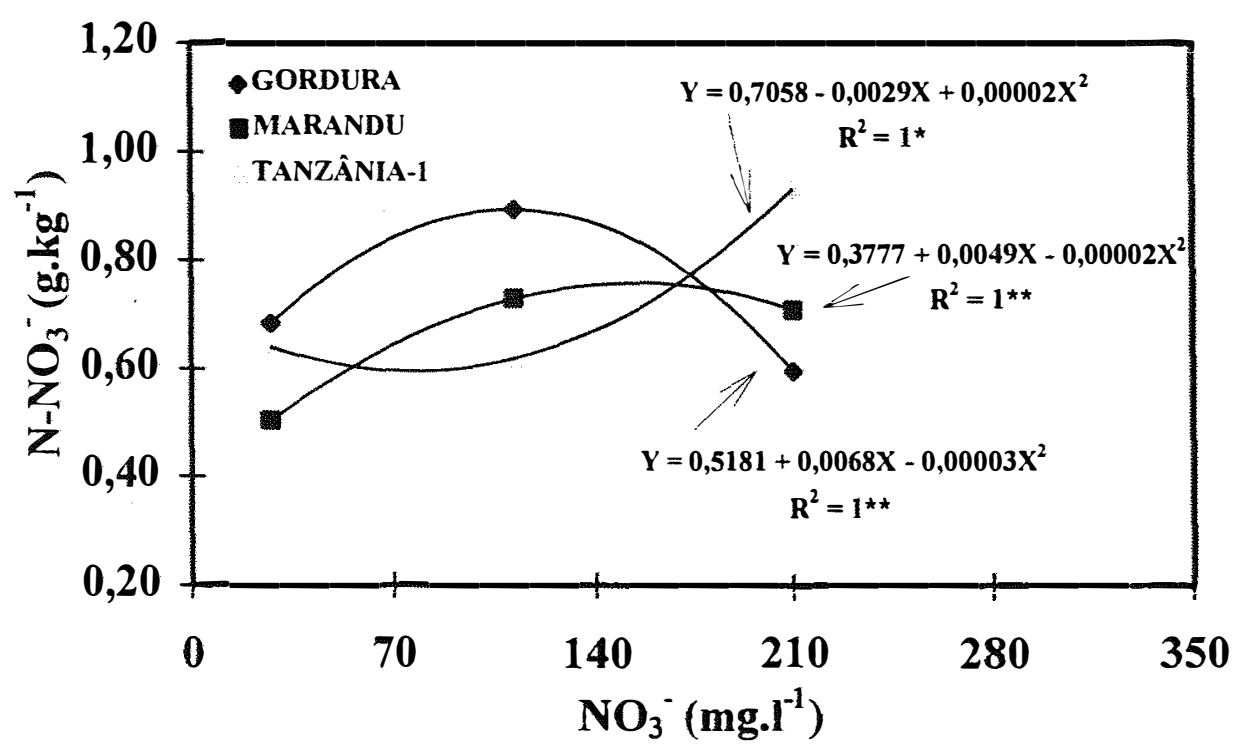

- C.V. $=8,65 \%$

- DMS Tukey a 5\% (média das espécies e dos níveis) $=0,07$

- DMS Tukey a 5\% (interação entre fatores) $=0,13$

Figura 17. Concentração de $\mathrm{N}-\mathrm{NO}_{3}{ }^{-}\left(\mathrm{g}\right.$ de N$\left.\cdot \mathrm{kg}^{-1}\right)$ na matéria seca da parte aérea dos capins gordura, Marandu e Tanzânia-1 sob níveis de nitrato em solução nutritiva.

A concentração de nitrato na matéria seca das folhas novas mostrou valores ligeiramente inferiores aos das folhas velhas, a qual também teve teores ligeiramente inferiores aos dos colmos + bainhas, como mostram respectivamente as figuras 18,19 e 20 . Este fato pode ser explicado pelo exposto por CAMPBELL (1988), de que a atividade metabólica é maior nas folhas novas, o que faz reduzir o seu acúmulo nitrato.

$\mathrm{O}$ teor de nitrato nas folhas novas foi significativamente mais elevado $(\mathrm{P}<0,05)$ no nível 210 do que no nível $28 \mathrm{mg}$ de $\mathrm{NO}_{3} \cdot \mathrm{l}^{-1}$. Não se encontrou diferença significativa $(P>0,05)$ entre as espécies estudadas. 


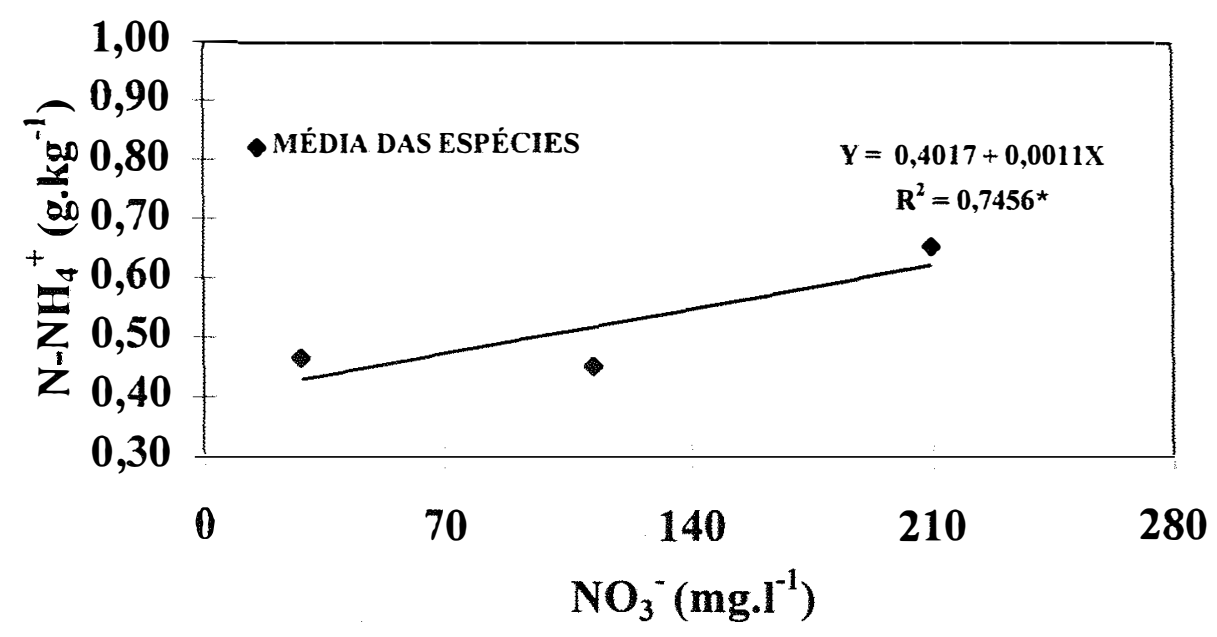

- C.V. $=30,7 \%$

- DMS Tukey a 5\% (média das espécies e dos níveis) =0,19

Figura 18. Concentração de $\mathrm{N}_{-} \mathrm{NO}_{3}^{-}\left(\mathrm{g}\right.$ de $\left.\mathrm{N} \cdot \mathrm{kg}^{-1}\right)$ nas folhas novas dos capins gordura, Marandu e Tanzânia-1 sob três níveis de nitrato em solução nutritiva

A concentração de nitrato nas folhas velhas dos capins não foi alterada significativamente $(P>0,05)$ pelos níveis de nitrato na solução e nem variou com as espécies, como demonstrado na figura 19.

O teor de nitrato nos colmos + bainhas diferiu significativamente $(\mathrm{P}<0,05)$ entre os níveis de nitrato, tendo o nível mais elevado do nutriente na solução resultado em concentração de nitrato mais elevada do que nos demais níveis testados. Na comparação entre as espécies foi possível verificar que o teor de nitrato nos colmos + bainhas do capim-Tanzânia-1 foi significativamente ( $\mathrm{P}<$ $0,05)$ superior ao do capim-gordura. O estudo da interação entre espécies e níveis de nitrato evidenciou que para o nível mais elevado de nitrato na solução o capimTanzânia-1 diferiu do capim-gordura. 


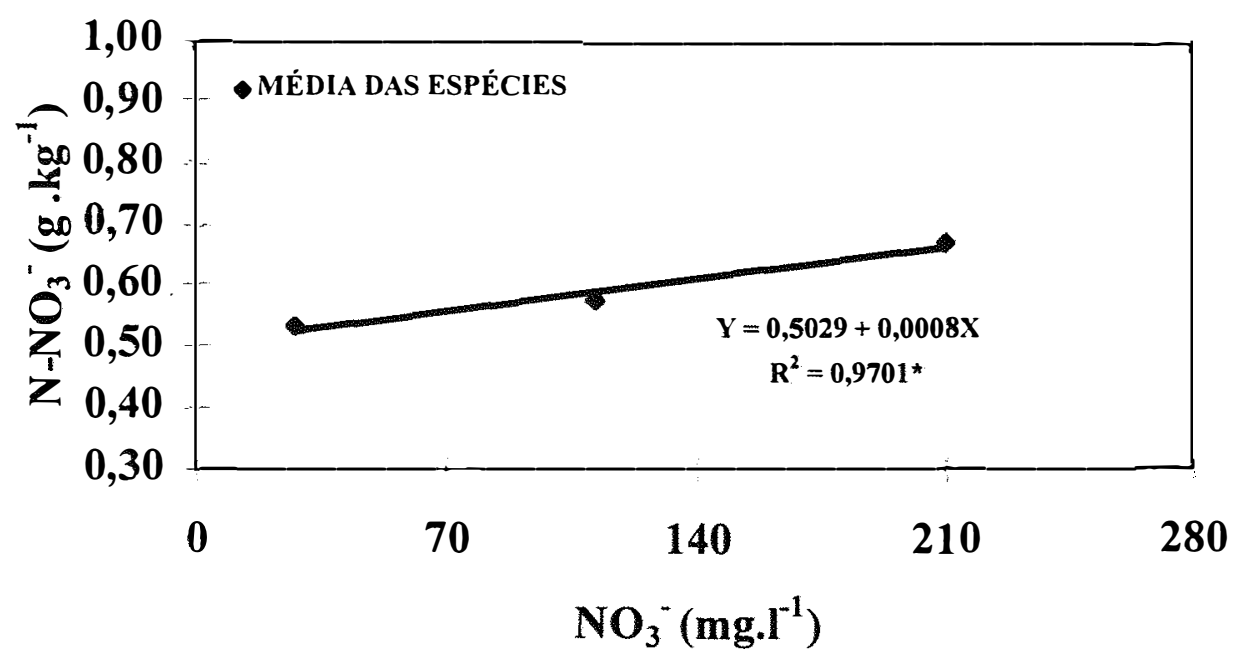

- C.V. $=21,7 \%$

- DMS Tukey a 5\% (média das espécies e dos níveis) $=0,17$

Figura 19. Concentração de $\mathrm{N}_{-} \mathrm{NO}_{3}^{-}\left(\mathrm{g}\right.$ de N. $\mathrm{kg}^{-1}$ ) nas folhas velhas dos capins gordura, Marandu e Tanzânia-1 sob três níveis de nitrato em solução nutritiva.

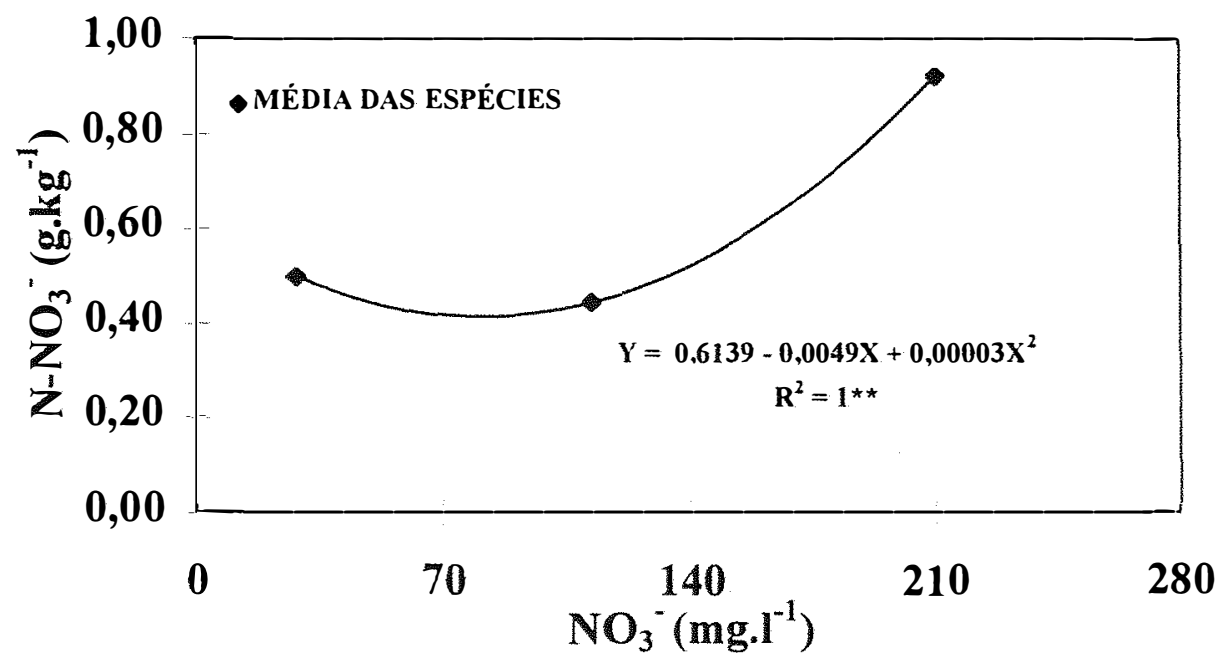

- C.V. $=32,7 \%$

- DMS Tukey a 5\% (média das espécies e dos níveis) $=0,62$

Figura 20. Concentração de $\mathrm{N}_{-} \mathrm{NO}_{3}^{-}\left(\mathrm{g}\right.$ de $\left.\mathrm{N} \cdot \mathrm{kg}^{-1}\right)$ nos colmos + bainhas dos capins gordura, Marandu e Tanzânia-1 sob níveis de nitrato em solução nutritiva. 
A concentração de nitrato nas raízes das forrageiras apresentou diferença significativa $(\mathrm{P}<0,05)$ entre os níveis 210 e $112 \mathrm{mg}$ de $\mathrm{NO}_{3}^{-} .1^{-1}$. Isto talvez possa ser explicado pela quantidade absorvida de nitrato em relação à atividade da enzima redutase do nitrato no total da planta, como sugerido por SCHRADER et al. (1972).

Para as espécies estudadas também foi verificada diferença significativa $(P<0,05)$ entre o maior teor de nitrato do capim-Marandu em relação ao do capim-gordura. Variação desse tipo foi encontrada por IMPITHUSKA \& BLUE (1985) e pode sugerir que este órgão funcionaria como armazenador de nitrogênio, embora deva-se destacar que esses valores são relativamente baixos.

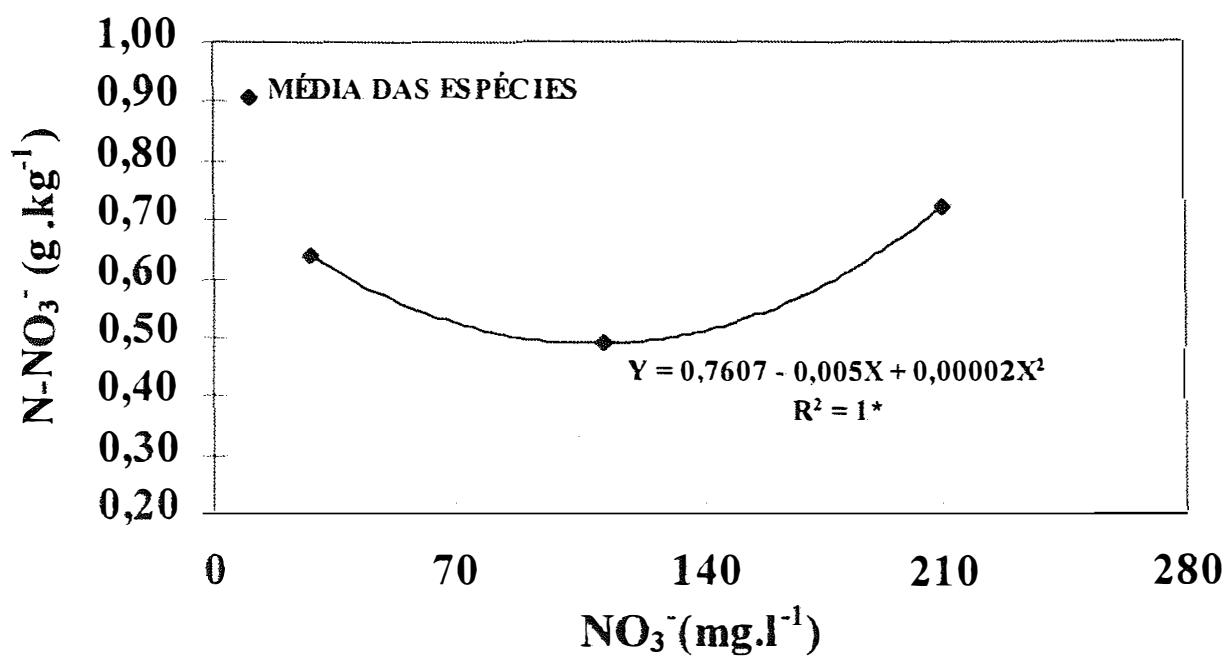

- C.V. $=25,9 \%$

- DMS Tukey a 5\% (média das espécies e dos níveis) =0,19

Figura 21. Concentração de $\mathrm{N}-\mathrm{NO}_{3}{ }^{-}\left(\mathrm{g}_{\text {de N}} \mathrm{kg}{ }^{-1}\right)$ da matéria seca das raízes nos capins gordura, Marandu e Tanzânia-1 sob níveis de nitrato em solução nutritiva. 


\subsubsection{Efeito dos níveis de nitrato sobre a atividade da redutase do nitrato}

A elevação dos níveis de nitrato na solução nutritiva resultou em aumentos significativos $(\mathrm{P}<0,01)$ da atividade da redutase do nitrato na folha dos capins estudados, com diferenças significativas $(P<0,05)$ entre os três níveis de nitrato.

A atividade dessa enzima não variou significativamente $(\mathrm{P}>$ $0,05)$ entre as espécies, bem como não foi significativa $(P>0,05)$ a interação entre espécies e níveis de nitrato na solução nutritiva (Figura 22).

Os resultados do presente experimento foram menores que os obtidos por FERNANDES \& FREIRE (1976) para Brachiaria sp., quando foram utilizados níveis de nitrato em solo de até $80 \mathrm{mg}$ de nitrato por quilograma de solo. Contudo, deve-se ressaltar que o maior período de crescimento pode ter influenciado a resposta.

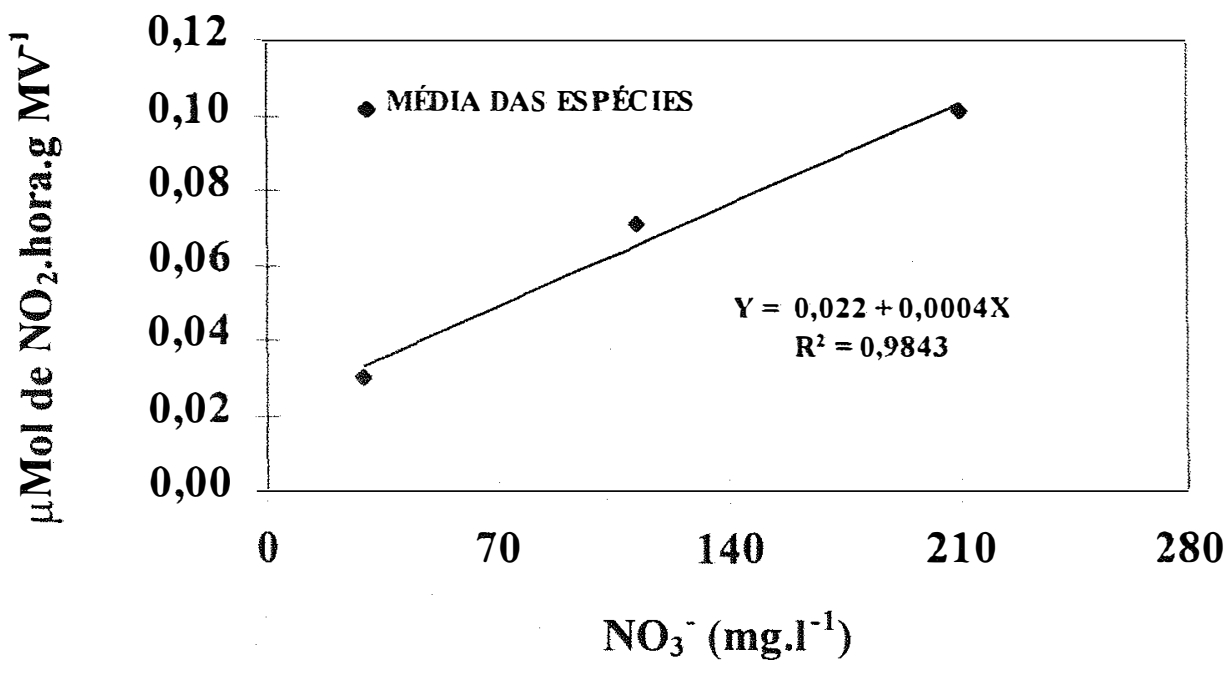

- C.V. $=30,7 \%$

- DMS Tukey a 5\% (média das espécies e dos níveis) $=0,025$

Figura 22. Atividade da redutase do nitrato $\left(\mu\right.$ moles de $\mathrm{NO}_{2} /$ grama de material fresco / hora) nos capins gordura, Marandu e Tanzânia-1 sob níveis de nitrato em solução nutritiva. 


\subsection{Segundo experimento}

\subsubsection{Efeito das proporções de nitrato e amônio sobre o número de perfilhos}

A análise dos resultados do número de perfilhos por vaso demonstra efeitos significativos $(\mathrm{P}<0,01)$ para as proporções de nitrato e amônio e para as espécies forrageiras. As proporções de formas de nitrogênio 100/0 e $75 / 25(-\mathrm{Ca})$ resultaram em desempenhos significativamente $(\mathrm{P}<0,05)$ superiores às demais, como apresentado na tabela 3 .

Tabela 3. Número de perfilhos por vaso dos capins gordura, Marandu e Tanzânia-1 sob proporções de $\mathrm{NO}_{3}{ }^{-}$e $\mathrm{NH}_{4}{ }^{+}$em solução nutritiva.

\begin{tabular}{|c|c|c|c|c|c|c|c|c|}
\hline \multirow{3}{*}{$\begin{array}{c}\begin{array}{c}\text { Proporção de } \\
\mathrm{NO}_{3}^{-} / \mathrm{NH}_{4}^{+} \\
(\%)\end{array} \\
100 / 0\end{array}$} & \multicolumn{6}{|c|}{ Espécies } & \multirow{2}{*}{\multicolumn{2}{|c|}{ Média }} \\
\hline & \multicolumn{2}{|c|}{ Gordura } & \multicolumn{2}{|c|}{ Marandu } & \multicolumn{2}{|c|}{ Tanzânia-1 } & & \\
\hline & 56,33 & $\mathrm{ABa}$ & 50,67 & $\mathrm{Aa}$ & 25,00 & $\mathrm{Ab}$ & 44,00 & A \\
\hline $75 / 25$ & 48,67 & $\mathrm{BCa}$ & 34,67 & $\mathrm{Bb}$ & 12,00 & $\mathrm{Bc}$ & 31,78 & $\mathrm{~B}$ \\
\hline $75 / 25(-\mathrm{Ca})$ & 62,00 & $\mathrm{Aa}$ & 46,33 & $\mathrm{Ab}$ & 25,67 & Ac & 44,67 & A \\
\hline $50 / 50$ & 43,33 & $\mathrm{Ca}$ & 30,67 & $\mathrm{Bb}$ & 14,67 & $\mathrm{Bc}$ & 29,89 & B \\
\hline $25 / 75$ & 48,00 & $\mathrm{Ca}$ & 32,00 & $\mathrm{Bb}$ & 15,33 & $\mathrm{Bc}$ & 31,78 & $\mathrm{~B}$ \\
\hline Média & 51,87 & $\mathrm{a}$ & 38,87 & b & 18,53 & c & 36,42 & \\
\hline
\end{tabular}

- DMS Tukey a $5 \%$ (média entre espécies e entre proporções) $=3,10$ e 4,71

- DMS Tukey a 5\% (proporções dentro de espécie e espécies dentro de proporção) = 8,16 e 6,94

- Valores das colunas seguidos das mesmas letras maiúsculas e das linhas por letras minúsculas não diferem entre si.

O capim-gordura apresentou o maior perfilhamento com diferença significativa $(P<0,01)$ sobre o capim-Marandu, o qual também teve mais perfilhos do que o capim-Tanzânia-1 $(\mathrm{P}<0,01)$. Considerando-se a 
interação, observou-se o efeito de espécie dentro das proporções apenas para o capim-gordura com superioridade apenas no tratamento em ausência de cálcio, o qual foi superior aos demais, em valor absoluto, apesar de não diferir da proporção $100 / 0$, que por sua vez foi igual a proporção $75 / 25 \%$ de nitrato e amônio. Estes valores para o capim-gordura demonstram um gradiente de resposta entre a maior e as menores proporções de nitrato e amônio.

Estes resultados são reflexo da propriedade de perfilhamento de cada espécie, como destacaram OTERO (1961) e BOGDAN (1971).

\subsubsection{Efeito das proporções de nitrato e amônio sobre a produção de matéria seca}

O rendimento de matéria seca da parte aérea sofreu influência da proporção de $\mathrm{NO}_{3}{ }^{-} \mathrm{NH}_{4}{ }^{+}$, sendo que as proporções 100/0 e 75/25 (-Ca) foram iguais entre si e significativamente $(\mathrm{P}<0,05)$ superiores às demais proporções.

Obteve-se efeito para o fator espécie, evidenciado pela média de cada planta, com diferença $(\mathrm{P}<0,05)$ entre os capins Tanzânia-1 e gordura, que foram iguais ao capim-Marandu. Esses resultados confirmam as produções de matéria seca apresentadas por estas forrageiras, em diversos trabalhos envolvendo comparação entre espécies (CARO-COSTAS et al., 1960; OLSEN, 1972; PEDREIRA, 1973; PEDREIRA \& MATTOS, 1981; ALVIM, 1990).

Não houve significancia $(P>0,05)$ para a interação entre os fatores para produção de matéria seca da parte aérea. Entretanto, observa-se para a maior concentração de nitrato a superioridade do capim-Tanzânia-1 sobre o capim-Marandu, que foi superior ao capim-gordura. Desempenho inverso foi obtido na proporção $75 / 25 \%$ de nitrato e amônio, e valores absolutos praticamente idênticos foram encontrados entre as três espécies em ausência de cálcio. 
Verificaram-se produções idênticas para os capins gordura e Marandu, nas proporções 100/0 e 75/25\% em ausência de cálcio, enquanto o capim-Tanzânia-1 reduziu a produção com o aumento de amônio associado a ausência de cálcio. Esse resultado difere daquele obtido por SILVEIRA (1981) e ANDRADE (1994), ambos com Panicum maximum Jacq, nos quais verificaramse aumentos da produção de matéria seca com aumentos da proporção de amônio, ao se utilizar condições experimentais diferentes do presente estudo. Entretanto, a redução de produção, com o aumento da participação de amônio acima de $50 \%$, é menor para o capim-Tanzânia-1 em relação ao capim-gordura.

Tabela 4. Rendimento de matéria seca da parte aérea $\left(\right.$ g.vaso $^{-1}$ ) dos capins gordura, Marandu e Tanzânia-1 sob proporções de $\mathrm{NO}_{3}{ }^{-}$e $\mathrm{NH}_{4}^{+}$em solução nutritiva.

\begin{tabular}{|c|c|c|c|c|c|}
\hline \multirow{2}{*}{$\begin{array}{c}\text { Proporção de } \\
\mathrm{NO}_{3}^{-} / \mathrm{NH}_{4}^{+} \\
(\%) \\
\end{array}$} & \multicolumn{3}{|c|}{ Espécies } & \multirow{2}{*}{\multicolumn{2}{|c|}{ Média }} \\
\hline & Gordura & Marandu & Tanzânia-1 & & \\
\hline $100 / 0$ & 29,81 & 32,81 & 36,27 & 32,96 & A \\
\hline $75 / 25$ & 25,89 & 24,63 & 21,05 & 23,86 & $\mathrm{~B}$ \\
\hline $75 / 25(-\mathrm{Ca})$ & 30,71 & 33,68 & 32,92 & 32,43 & A \\
\hline $50 / 50$ & 19,71 & 24,58 & 23,51 & 22,60 & $\mathrm{~B}$ \\
\hline $25 / 75$ & 16,31 & 17,59 & 26,14 & 25,04 & $\mathrm{~B}$ \\
\hline Média & 24,49 & 26,66 & 27,98 & 26,38 & \\
\hline
\end{tabular}

- C.V. $=14,4 \%$

- DMS Tukey a 5\% (média entre espécies e entre proporções) =3,43 e 5,22

- Valores das colunas seguidos das mesmas letras maiúsculas e das linhas por letras minúsculas não diferem entre si.

O capim-Marandu mostrou as maiores produções de matéria seca nos tratamentos com proporções $100 / 0$ e 75/25 em ausência de cálcio. Por sua vez 
MONTEIRO et al. (1994) obtiveram para o capim-Marandu, produção com proporção $75 / 25 \%$ de nitrato / amônio na ausência de cálcio quase duas vezes maior que da proporção 100/0\%. A ocorrência desta diferença de resultados deve ser devida ao maior período de crescimento no presente experimento, que possivelmente igualou os dois tratamentos ao final do período de avaliação neste trabalho.

As informações encontradas na literatura colocam que as maiores produções de matéria seca são obtidas com a utilização das duas formas de nitrogênio na solução, e que se mostram superiores à utilização de apenas uma delas (SCHARADER et al., 1972; LEWIS et al., 1982). Resultados apresentados por COX \& REISENAUER (1973) demonstram este efeito para menor período de crescimento em plantas de trigo, em solução com $200 \mu \mathrm{M}$ de nitrato e $40 \mu \mathrm{M}$ de amônio.

O rendimento de folhas novas (Tabela 5) teve um comportamento um pouco diferente do obtido para o total da parte aérea. Para a média de cada proporção de nitrato e amônio, as produções de matéria seca das folhas novas, apresentaram diferenças significativas $(\mathrm{P}<0,05)$ apenas entre os tratamentos $100 / 0$ e $25 / 75$. Este resultado pode ter explicação pelo exposto na literatura sobre o efeito tóxico de altas concentrações de amônio (COX \& REISENAUER, 1973 e CAUSIN et al., 1992) ou até mesmo sintomas de estresse hídrico, o que pode ter acarretado redução no desenvolvimento de folhas novas para as plantas, aqui estudadas na maior concentração de amônio, já que ocorre uma redução gradativa de matéria seca de folhas novas da solução com menor para a de maior concentração de amônio.

O comportamento geral das espécies quanto à produção de matéria seca de folhas novas mostra que o capim-Marandu é a planta com melhor desempenho, evidenciando a sua menor taxa de aparecimento de folhas e/ou maior tempo para início da senescência das folhas, o que está de acordo com os 
resultados apresentados por EMBRAPA (1985) ao comparar também os capins Marandu e colonião.

A interação entre os fatores foi significativa $(P<0,01)$. O capimMarandu teve a menor produção de folhas novas, exatamente na proporção com maior concentração de amônio, o que pode evidenciar sua menor tolerância a elevados níveis de amônio, em relação às demais forrageiras, apesar de apresentar percentuais de folhas novas, em relação a matéria seca da parte aérea, sempre superiores a $27 \%$, enquanto que o capim-gordura não superou $20 \%$ e o capimTanzânia-1 30\%, somente na proporção 75/25\% de nitrato e amônio. Resultados com o gênero Brachiaria obtidos no CIAT (1983) mostram a adaptação da Brachiaria humidicola Schweickt a elevadas concentrações de amônio.

A baixa proporção de matéria seca das folhas novas no capimgordura pode ter sido devido ao intenso perfilhamento, que reduziu a área iluminada e o espaço para o aparecimento de novos perfilhos, e consequentemente novas folhas. É fundamental o conhecimento, da dinâmica do aparecimento de perfilhos por planta e a quantidade de folhas por perfilho, através de novos estudos.

O rendimento obtido como matéria seca das folhas velhas demonstrou, para a média das proporções de nitrato e amônio, a mesma tendência verificada para a matéria seca da parte aérea, tendo os tratamentos 100/0 e $75 / 25 \%$ em ausência de cálcio apresentado desempenhos superiores aos das outras proporções (Tabela 6). Para esta variável o capim-Tanzânia-1 revelou produção significativamente $(P<0,05)$ maior que das outras duas espécies evidenciando o seu rápido crescimento inicial. Entretanto, o capim-Tanzânia-1 foi igual aos demais nas proporções $75 / 25$ e 50/50\% de nitrato e amônio. Resultados compilados de WHITEMAN (1980) mostraram que com a melhoria das condições de crescimento, as forrageiras do gênero Panicum apresentaram aumentos, da taxa de desenvolvimento da área foliar, superiores aos dos gêneros Brachiaria e Melinis, o que está de acordo com o resultado obtido neste trabalho. 
Tabela 5. Rendimento de matéria seca das folhas novas (g.vaso ${ }^{-1}$ ) dos capins gordura, Marandu e Tanzânia-1 sob proporções de $\mathrm{NO}_{3}^{-}$e $\mathrm{NH}_{4}^{+}$em solução nutritiva.

\begin{tabular}{|c|c|c|c|c|c|c|c|c|}
\hline \multirow{3}{*}{$\begin{array}{c}\text { Proporção de } \\
\mathrm{NO}_{3}^{-} \mathrm{NH}_{4}^{+} \\
(\%)\end{array}$} & \multicolumn{6}{|c|}{ Espécies } & \multirow{2}{*}{\multicolumn{2}{|c|}{ Média }} \\
\hline & \multicolumn{2}{|c|}{ Gordura } & \multicolumn{2}{|c|}{ Marandu } & \multicolumn{2}{|c|}{ Tanzânia-1 } & & \\
\hline & 4,86 & $\mathrm{Ab}$ & 10,02 & $\mathrm{Aa}$ & 6,56 & $\mathrm{Ab}$ & 7,15 & $\mathrm{~A}$ \\
\hline $75 / 25$ & 4,80 & Abc & 8,25 & $\mathrm{Aa}$ & 6,46 & $\mathrm{Ab}$ & 6,17 & $\mathrm{AB}$ \\
\hline $75 / 25(-\mathrm{Ca})$ & 4,37 & $\mathrm{Ab}$ & 9,54 & $\mathrm{Aa}$ & 3,82 & $\mathrm{Ab}$ & 5,91 & $\mathrm{AB}$ \\
\hline $50 / 50$ & 3,47 & $\mathrm{Ab}$ & 8,22 & $\mathrm{Aa}$ & 5,92 & $\mathrm{Aab}$ & 5,87 & $\mathrm{AB}$ \\
\hline $25 / 75$ & 3,22 & $\mathrm{Ab}$ & 4,80 & $\mathrm{Bab}$ & 6,05 & $\mathrm{Aa}$ & 4,70 & $\mathrm{~B}$ \\
\hline Média & 4,14 & c & 8,17 & $\mathrm{a}$ & 5,56 & $\mathrm{~b}$ & 5,96 & \\
\hline
\end{tabular}

- C.V. $=21,5 \%$

- DMS Tukey a 5\% (média entre espécies e entre proporções) = 1,16 e 1,8

- DMS Tukey a 5\% (proporções dentro de espécie e espécies dentro de proporção) =3,06 e 2,6

- Valores das colunas seguidos das mesmas letras maiúsculas e das linhas por letras minúsculas não diferem entre si.

A produção de matéria seca de colmos + bainhas foi significativamente $(\mathrm{P}<0,05)$ maior nos tratamentos com proporções mais elevadas de nitrato na solução nutritiva (Tabela 7). Para esta variável, o capimgordura apresentou resultados significativamente $(\mathrm{P}<0,05)$ maiores que os outros dois capins, o que foi um reflexo do elevado número de perfilhos.

A interação das espécies com as proporções foi significativa $(\mathrm{P}<$ 0,05). Para os tratamentos com mais de $50 \%$ de amônio na solução nutritiva, as três forrageiras foram iguais $(\mathrm{P}>0,05)$. Este efeito, na maior parte, foi devido a maior estratificação de resposta do capim-gordura entre as proporções de nitrato e amônio, a qual foi uniforme para o capim-Tanzânia-1. 
Tabela 6. Rendimento de matéria seca das folhas velhas (g.vaso ${ }^{-1}$ ) dos capins gordura, Marandu e Tanzânia-1 sob proporções de $\mathrm{NO}_{3}^{-}$e $\mathrm{NH}_{4}^{+}$em solução nutritiva.

\begin{tabular}{|c|c|c|c|c|c|c|c|c|}
\hline \multirow{3}{*}{$\begin{array}{c}\text { Proporção de } \\
\mathrm{NO}_{3}{ }^{-} / \mathrm{NH}_{4}^{+} \\
(\%)\end{array}$} & \multicolumn{6}{|c|}{ Espécies } & \multirow{2}{*}{\multicolumn{2}{|c|}{ Média }} \\
\hline & \multicolumn{2}{|c|}{ Gordura } & \multicolumn{2}{|c|}{ Marandu } & \multicolumn{2}{|c|}{ Tanzânia-1 } & & \\
\hline & 9,01 & $\mathrm{ABb}$ & 9,84 & $\mathrm{ABb}$ & 17,75 & $\mathrm{Aa}$ & 12,20 & $\mathrm{~A}$ \\
\hline $75 / 25$ & 6,32 & $\mathrm{ABa}$ & 5,55 & $\mathrm{Ba}$ & 7,46 & $\mathrm{Ba}$ & 6,44 & $\mathrm{~B}$ \\
\hline 75/25 (-Ca) & 9,62 & $\mathrm{Ab}$ & 11,61 & $\mathrm{Ab}$ & 19,92 & $\mathrm{Aa}$ & 13,72 & A \\
\hline $50 / 50$ & 5,86 & $\mathrm{ABa}$ & 5,73 & $\mathrm{Ba}$ & 9,41 & $\mathrm{Ba}$ & 7,00 & $\mathrm{~B}$ \\
\hline $25 / 75$ & 4,34 & $\mathrm{Bb}$ & 5,50 & $\mathrm{Bb}$ & 10,38 & $\mathrm{Ba}$ & 6,74 & $\mathrm{~B}$ \\
\hline Média & 7,03 & b & 7,65 & b & 12,98 & $\mathrm{a}$ & 9,22 & \\
\hline
\end{tabular}

- C.V. $=24 \%$

- DMS Tukey a 5\% (média entre espécies e entre proporções) = 1,99 e 3,04

- DMS Tukey a 5\% (proporções dentro de espécie e espécies dentro de proporção) = 5,27 e 4,47

- Valores das colunas seguidos das mesmas letras maiúsculas e das linhas por letras minúsculas não diferem entre si.

O rendimento de matéria seca das raízes (Tabela 8) foi significativamente $(\mathrm{P}<0,05)$ maior para as proporções 100/0 e 75/25 (-Ca) do que nas demais proporções, demonstrando o efeito negativo de elevadas proporções de amônio sobre a produção desta fração, tal como nos resultados obtidos por SILVEIRA (1981), embora que a proporção $75 / 25 \%$ não tenha diferido das proporções menos produtivas. ANDRADE (1994) obteve reduções na produção das raízes de capim-colonião cultivar Vencedor apenas para a utilização de amônio como única fonte de nitrogênio. COX \& REISENAUER (1973) obtiveram reduções de produção de raízes para trigo, a partir dos níveis de $80 \mu \mathrm{M}$ de amônio, associado a $200 \mu \mathrm{M}$ de nitrato. 
Tabela 7. Rendimento de matéria seca dos colmos e bainhas (g.vaso ${ }^{-1}$ ) dos capins gordura, Marandu e Tanzânia-1 sob proporções de $\mathrm{NO}_{3}{ }^{-}$e $\mathrm{NH}_{4}{ }^{+}$ em solução nutritiva.

\begin{tabular}{c|cc|cc|cc|cc|}
\hline $\begin{array}{c}\text { Proporção de } \\
\mathrm{NO}_{3}{ }^{-} / \mathrm{NH}_{4}{ }^{+} \\
(\%)\end{array}$ & \multicolumn{7}{|c|}{ Espécies } & \multicolumn{2}{|c}{ Média } \\
\cline { 2 - 8 } & Gordura & \multicolumn{2}{|c|}{ Marandu } & Tanzânia-1 & & \\
\hline $100 / 0$ & 15,94 & $\mathrm{Aa}$ & 12,94 & $\mathrm{Aab}$ & 11,96 & $\mathrm{Ab}$ & 13,62 & $\mathrm{~A}$ \\
\hline $75 / 25$ & 14,77 & $\mathrm{ABa}$ & 10,83 & $\mathrm{ABb}$ & 8,14 & $\mathrm{Ab}$ & 11,25 & $\mathrm{AB}$ \\
\hline $75 / 25(-\mathrm{Ca})$ & 16,73 & $\mathrm{Aa}$ & 12,52 & $\mathrm{Ab}$ & 9,17 & $\mathrm{Ab}$ & 12,81 & $\mathrm{~A}$ \\
\hline $50 / 50$ & 10,38 & $\mathrm{BCa}$ & 10,61 & $\mathrm{ABa}$ & 8,17 & $\mathrm{Aa}$ & 9,72 & $\mathrm{BC}$ \\
\hline $25 / 75$ & 8,74 & $\mathrm{Ca}$ & 7,29 & $\mathrm{Ba}$ & 9,71 & $\mathrm{Aa}$ & 8,58 & $\mathrm{C}$ \\
\hline Média & 13,31 & $\mathrm{a}$ & 10,84 & $\mathrm{~b}$ & 9,43 & $\mathrm{~b}$ & 11,19 & \\
\hline
\end{tabular}

- C.V. $=16,6 \%$

- DMS Tukey a 5\% (média entre espécies e entre proporções) $=1,68$ e 2,55

- DMS Tukey a $5 \%$ (proporções dentro de espécie e espécies dentro de proporção) = 4,41 e 3,75

- Valores das colunas seguidos das mesmas letras maiúsculas e das linhas por letras minúsculas não diferem entre si.

As gramíneas estudadas apresentaram diferenças significativas ( $\mathrm{P}$ $<0,05)$ para a produção de matéria seca de raizes, tendo o capim-Marandu mostrado produção maior que o Tanzânia-1, que por sua vez foi superior ao gordura. Entretanto, deve-se ressaltar que as raizes de capim-gordura apresentavam maior volume devido ao menor diâmetro, em comparação com as demais forrageiras.

As proporções não afetaram significativamente $(P>0,05)$ a produção de matéria seca das raízes do capim-gordura. O capim-Marandu apresentou diferença significativa $(\mathrm{P}<0,05)$ para as proporções estudadas, tendo seu melhor desempenho na proporção 75/25\% (-Ca), embora sem diferir significativamente da proporção 100/0 de nitrato e amônio. Isto provavelmente possa ser explicado pela rápida assimilação de amônio nesta condição, como ressaltaram COX \& REISENAUER (1973), SRIVASTAVA (1980) e NAIR \& 
CHATERJEE (1990), provocando um aumento na síntese de proteínas. O efeito, que pudesse existir, da redução do $\mathrm{pH}$ não foi sentido como nas proporções de $50 / 50$ e 25/75, bem como o equilíbrio cátio-aniônico deve ter influenciado grandemente esta resposta, considerando-se que para todas as forrageiras, a proporção em ausência de cálcio, foi igual a maior proporção de nitrato.

Tabela 8. Rendimento da matéria seca das raízes (g.vaso ${ }^{-1}$ ) dos capins gordura, Marandu e Tanzânia-1 sob proporções de $\mathrm{NO}_{3}^{-}$e $\mathrm{NH}_{4}^{+}$em solução nutritiva.

\begin{tabular}{|c|c|c|c|c|c|c|c|c|}
\hline \multirow{3}{*}{$\begin{array}{c}\begin{array}{c}\text { Proporção de } \\
\mathrm{NO}_{3}^{-} \mathrm{NH}_{4}^{+} \\
(\%)\end{array} \\
100 / 0\end{array}$} & \multicolumn{6}{|c|}{ Espécies } & \multirow{2}{*}{\multicolumn{2}{|c|}{ Média }} \\
\hline & \multicolumn{2}{|c|}{ Gordura } & \multicolumn{2}{|c|}{ Marandu } & \multicolumn{2}{|c|}{ Tanzânia-1 } & & \\
\hline & 4,28 & $\mathrm{Ab}$ & 10,76 & $\mathrm{ABa}$ & 10,39 & $\mathrm{Aa}$ & 8,48 & $\mathrm{~A}$ \\
\hline $75 / 25$ & 5,28 & $\mathrm{Ab}$ & 8,01 & $\mathrm{BCa}$ & 6,15 & $\mathrm{Bab}$ & 6,48 & $\mathrm{~B}$ \\
\hline $75 / 25(-\mathrm{Ca})$ & 3,95 & Ac & 12,53 & $\mathrm{Aa}$ & 8,30 & $\mathrm{ABb}$ & 8,26 & $\mathrm{AB}$ \\
\hline $50 / 50$ & 3,54 & $\mathrm{Ab}$ & 7,62 & $\mathrm{Ca}$ & 6,67 & $\mathrm{Ba}$ & 5,95 & $\mathrm{~B}$ \\
\hline $25 / 75$ & 3,63 & $\mathrm{Ab}$ & 5,22 & $\mathrm{Cab}$ & 6,22 & $\mathrm{Ba}$ & 5,03 & B \\
\hline Média & 4,14 & $\mathrm{c}$ & 8,83 & $\mathrm{a}$ & 7,54 & $\mathrm{~b}$ & 6,84 & \\
\hline
\end{tabular}

- DMS Tukey a $5 \%$ (média entre espécies e entre proporções) $=1,11$ e 1,69

- DMS Tukey a 5\% (proporções dentro de espécie e espécies dentro de proporção) =2,93 e 2,49

- Valores das colunas seguidos das mesmas letras maiúsculas e das linhas por letras minúsculas não diferem entre si.

As três espécies apresentaram diferentes desempenhos em relação às proporções. O capim-gordura apresentou os valores mais baixos e uma reduzida quantidade de raizes em relação ao total de matéria seca, apesar de não ter havido diferença $(P>0,05)$ entre as proporções. O capim-Tanzânia-1 reduziu a produção de raizes $(\mathrm{P}<0,05)$, à medida que aumentou a participação de amônio 
na solução, exceto para a proporção em ausência de cálcio, o que difere do resultado obtido por MONTEIRO et al. (1994).

\subsubsection{Efeito das proporções de nitrato e amônio sobre a concentração de nitrogênio nos tecidos vegetais}

A concentração de nitrogênio na parte aérea foi significativamente $(\mathrm{P}<0,05)$ maior para a proporção $75 / 25(-\mathrm{Ca})$ em relação às demais. Os tratamentos 100/0, 75/25 e 25/75 não diferiram significativamente ( $P$ $<0,05$ ) entre si, e apenas o teor na proporção 100/0 diferiu do pior resultado que foi o da proporção 50/50 (Tabela 9). Estes resultados não estão de acordo com aqueles obtidos por SIL VEIRA (1981) e ANDRADE (1994) utilizando Panicum maximum, nos quais aumentou o teor de nitrogênio até a proporção de 50/50 de nitrato e amônio.

Os valores de concentração de nitrogênio na parte aérea (Tabela 9) são relativamente baixos se comparados com os obtidos na literatura (CAROCOSTAS et al., 1960, COWARD-LORD et al., 1974; FRANÇA \& HAAG, 1985; CARVALHO \& SARAIVA, 1987; BRUNET et al., 1988a; BOTREL et al. 1990 e MONTEIRO et al., 1994), provavelmente, devido ao maior período de crescimento deste experimento. Contudo, são semelhantes aos obtidos por GOMIDE (1966) e COWARD-LORD et al. (1974).

A verificação do maior teor de nitrogênio na parte aérea na proporção 75/25 (-Ca) reforça o aspecto da necessidade do balanço catioaniônico, favorecendo a maior quantidade de amônio absorvida, como destacou KIRKBY (1968), além da maior velocidade de absorção de nitrogênio quando as duas formas são utilizadas, como obtido por COX \& REISENAUER (1973) e LEWIS \& CHADWICK (1983).

Obteve-se diferença significativa entre as forrageiras $(\mathrm{P}<0,05)$ na concentração de nitrogênio na parte aérea para a média de cada espécie. $O$ 
capim-gordura apresentou média inferior aos capins Marandu e Tanzânia-1, possivelmente, devido a sua menor capacidade de utilização do nitrogênio em elevadas concentrações, como destaca o trabalho de CARO-COSTAS et al. (1960). O capim-Marandu apresentou os maiores valores de concentração de nitrogênio na parte aérea, embora não tenha diferido do capim-Tanzânia-1 ( $\mathrm{P}$ > 0,05). Este resultado pode ser explicado pela pequena redução de nitrogênio, que o capim-Marandu apresenta com o aumento do período de crescimento (SOTOMAYOR-RIOS et al., 1974).

Particularmente, para os capins Marandu e Tanzânia-1 o efeito da ausência de cálcio na proporção 75/25 foi bem marcante, tendo este tratamento resultado nas mais elevadas concentrações de nitrogênio na parte aérea. $\mathrm{O}$ capimgordura apresentou concentrações de nitrogênio na parte aérea iguais para todas as proporções.

Estes resultados permitem inferir que para o aproveitamento do amônio, os capins Marandu e Tanzânia-1 necessitam de um melhor balanço cátion-ânion.

O teor de nitrogênio nas folhas novas (Tabela 10) foi superior ao das folhas velhas, que por sua vez foi superior ao obtido nos colmos + bainhas, apresentados nas tabelas 11 e 12, respectivamente. Estes resultados comprovam a mobilidade do nitrogênio para as regiões de maior atividade metabólica, como descrito por MALA VOLTA (1980) e MENGEL \& KIRKBY (1987).

A concentração de nitrogênio nas folhas novas teve um comportamento, entre as proporções de nitrato / amônio, semelhante ao obtido na parte aérea, tendo a proporção 75/25 (-Ca) resultado em teor significativamente (P $<0,05)$ maior do que $75 / 25$ e 50/50 \% de nitrato e amônio. Verificou-se que o capim-gordura foi superior ao capim-Tanzânia-1 ( $\mathrm{P}<0,05)$, e igual ao capimMarandu, caracterizando a maior precocidade do Panicum, evidenciado pela sua pequena quantidade de folhas novas no momento do corte. 
Tabela 9. Concentração (em porcentagem) de nitrogênio na matéria seca da parte aérea dos capins gordura, Marandu e Tanzânia-1 sob proporções de $\mathrm{NO}_{3}{ }^{-}$e $\mathrm{NH}_{4}{ }^{+}$em solução nutritiva.

\begin{tabular}{|c|c|c|c|c|c|c|c|c|}
\hline \multirow{3}{*}{$\begin{array}{c}\begin{array}{c}\text { Proporção de } \\
\mathrm{NO}_{3}^{-} / \mathrm{NH}_{4}^{+} \\
(\%)\end{array} \\
100 / 0\end{array}$} & \multicolumn{6}{|c|}{ Espécies } & \multirow{2}{*}{\multicolumn{2}{|c|}{ Média }} \\
\hline & \multicolumn{2}{|c|}{ Gordura } & \multicolumn{2}{|c|}{ Marandu } & \multicolumn{2}{|c|}{ Tanzânia-1 } & & \\
\hline & 1,02 & $\mathrm{Aa}$ & 0,94 & $\mathrm{Bb}$ & 0,94 & $\mathrm{Ab}$ & 0,97 & $\mathrm{~B}$ \\
\hline $75 / 25$ & 0,81 & $\mathrm{Aa}$ & 0,98 & $\mathrm{Ba}$ & 0,84 & $\mathrm{Ba}$ & 0,88 & BC \\
\hline 75/25 (-Ca) & 0,93 & $\mathrm{Aa}$ & 1,30 & $\mathrm{Aa}$ & 1,15 & $\mathrm{Aa}$ & 1,13 & $\mathrm{~A}$ \\
\hline $50 / 50$ & 0,81 & $\mathrm{Aa}$ & 0,83 & $\mathrm{Ba}$ & 0,88 & $\mathrm{Ba}$ & 0,84 & $\mathrm{C}$ \\
\hline $25 / 75$ & 0,93 & $\mathrm{Aa}$ & 0,97 & $\mathrm{Ba}$ & 0,87 & $\mathrm{Ba}$ & 0,92 & $\mathrm{BC}$ \\
\hline Média & 0,90 & $\mathrm{~b}$ & 1,00 & $\mathrm{a}$ & 0,94 & $\mathrm{a}$ & 0,95 & \\
\hline
\end{tabular}

- DMS Tukey a $5 \%$ (média entre espécies e entre proporções) $=0,09$ e 0,13

- DMS Tukey a 5\% (proporções dentro de espécie e espécies dentro de proporção) $=0,22$ e 0,19

- Valores das colunas seguidos das mesmas letras maiúsculas e das linhas por letras minúsculas não diferem entre si.

Não houve diferença significativa $(P>0,05)$ na concentração de nitrogênio das folhas velhas (Tabela 11) entre os valores médios de cada espécie. Entretanto para a média das proporções o comportamento foi semelhante ao do nitrogênio na parte aérea, tendo a proporção $75 / 25 \%$ em ausência de cálcio apresentado as maiores concentrações.

A porcentagem do nitrogênio total dos colmos + bainhas teve seu maior valor absoluto na proporção 75/25 \% em ausência de cálcio, a qual não diferiu significativamente $(P>0,05)$ da proporção $100 / 0 \%$, mas diferiu de todas as demais. O desdobramento da interação entre os fatores revelou que no capimMarandu a proporção 75/25 \% em ausência de cálcio resultou em maior concentração de nitrogênio nos colmos + bainhas, em relação às demais proporções, como obtido também na parte aérea. Isto reforça para esta espécie a necessidade do equilíbrio catio-aniônico, como também ocorreu com a mesma 
forrageira no trabalho de MONTEIRO et al. (1994), em termos de produção de matéria seca e quantidade de nitrogênio total na planta.

Tabela 10. Concentração (em porcentagem) de nitrogênio na matéria seca das folhas novas dos capins gordura, Marandu e Tanzânia-1 sob proporções de $\mathrm{NO}_{3}^{-}$e $\mathrm{NH}_{4}^{+}$em solução nutritiva

\begin{tabular}{|c|c|c|c|c|c|}
\hline \multirow{2}{*}{$\begin{array}{c}\text { Proporção de } \\
\mathrm{NO}_{3}^{-} / \mathrm{NH}_{4}^{+} \\
(\%) \\
\end{array}$} & \multicolumn{3}{|c|}{ Espécies } & \multirow{2}{*}{\multicolumn{2}{|c|}{ Média }} \\
\hline & Gordura & Marandu & Tanzânia-1 & & \\
\hline $100 / 0$ & 1,56 & 1,24 & 1,35 & 1,38 & $\mathrm{AB}$ \\
\hline $75 / 25$ & 1,30 & 1,23 & 1,06 & 1,20 & $\mathrm{BC}$ \\
\hline 75/25(-Ca) & 1,43 & 1,56 & 1,48 & 1,49 & A \\
\hline $50 / 50$ & 1,24 & 1,03 & 0,96 & 1,08 & $\mathrm{C}$ \\
\hline $25 / 75$ & 1,36 & 1,24 & 1,29 & 1,30 & $\mathrm{ABC}$ \\
\hline Média & 1,38 & 1,26 & 1,23 & 1,29 & \\
\hline
\end{tabular}

- DMS Tukey a 5\% (média entre espécies e entre proporções) $=0,14$ e 0,22

- Valores das colunas seguidos das mesmas letras maiúsculas e das linhas por letras minúsculas não diferem entre si.

A concentração de nitrogênio nas raízes (Tabela 13) foi superior à da parte aérea e dos colmos + bainhas, mas inferior à das folhas novas. Os valores obtidos neste trabalho foram inferiores aos obtidos por FRANÇA \& HAAG (1985) para Panicum e MONTEIRO et al. (1994) para capim-Marandu. Não ocorreu diferença significativa $(P>0,05)$ no teor de nitrogênio nas raízes, como efeito das proporções, nem das espécies estudadas. 
Tabela 11. Concentração (em porcentagem) de nitrogênio na matéria seca das folhas velhas dos capins gordura, Marandu e Tanzânia-1 sob proporções de $\mathrm{NO}_{3}{ }^{-}$e $\mathrm{NH}_{4}{ }^{+}$em solução nutritiva.

\begin{tabular}{|c|c|c|c|c|c|}
\hline \multirow{2}{*}{$\begin{array}{c}\text { Proporção de } \\
\mathrm{NO}_{3}^{-} / \mathrm{NH}_{4}^{+} \\
(\%)\end{array}$} & \multicolumn{3}{|c|}{ Espécies } & \multirow{2}{*}{\multicolumn{2}{|c|}{ Média }} \\
\hline & Gordura & Marandu & Tanzânia-1 & & \\
\hline $100 / 0$ & 1,10 & 1,02 & 0,98 & 1,04 & $\mathrm{AB}$ \\
\hline $75 / 25$ & 0,94 & 1,07 & 0,88 & 0,96 & B \\
\hline $75 / 25(-\mathrm{Ca})$ & 1,06 & 1,32 & 1,26 & 1,22 & $\mathrm{~A}$ \\
\hline $50 / 50$ & 1,00 & 0,90 & 0,85 & 0,92 & $\mathrm{BC}$ \\
\hline $25 / 75$ & 0,98 & 1,03 & 0,89 & 0,98 & $\mathrm{~B}$ \\
\hline Média & 1,02 & 1,07 & 0,97 & 1,02 & \\
\hline
\end{tabular}

- C.V. $=18 \%$

- DMS Tukey a 5\% (média entre espécies e entre proporções) $=0,12$ e 0,18

- Valores das colunas seguidos das mesmas letras maiúsculas e das linhas por letras minúsculas não diferem entre si.

Tabela 12. Concentração (em porcentagem) de nitrogênio na matéria seca dos colmos + bainhas dos capins gordura, Marandu e Tanzânia-1 sob proporções de $\mathrm{NO}_{3}^{-}$e $\mathrm{NH}_{4}^{+}$em solução nutritiva.

\begin{tabular}{|c|c|c|c|c|c|c|c|c|}
\hline \multirow{2}{*}{$\begin{array}{c}\text { Proporção de } \\
\mathrm{NO}_{3}^{-} / \mathrm{NH}_{4}^{+} \\
(\%)\end{array}$} & \multicolumn{6}{|c|}{ Espécies } & \multirow{2}{*}{\multicolumn{2}{|c|}{ Média }} \\
\hline & \multicolumn{2}{|c|}{ Gordura } & \multicolumn{2}{|c|}{ Marandu } & \multicolumn{2}{|c|}{ Tanzânia-1 } & & \\
\hline $100 / 0$ & 0,81 & $\mathrm{Aa}$ & 0,68 & $\mathrm{Ba}$ & 0,64 & $\mathrm{Aa}$ & 0,71 & $\mathrm{AB}$ \\
\hline $75 / 25$ & 0,59 & $\mathrm{Aa}$ & 0,77 & $\mathrm{Ba}$ & 0,65 & $\mathrm{Aa}$ & 0,67 & B \\
\hline $75 / 25(-\mathrm{Ca})$ & 0,76 & $\mathrm{Ab}$ & 1,19 & $\mathrm{Aa}$ & 0,80 & $\mathrm{Ab}$ & 0,92 & A \\
\hline $50 / 50$ & 0,55 & $\mathrm{Aa}$ & 0,62 & $\mathrm{Ba}$ & 0,85 & $\mathrm{Aa}$ & 0,68 & B \\
\hline $25 / 75$ & 0,74 & $\mathrm{Aa}$ & 0,73 & $\mathrm{Ba}$ & 0,64 & $\mathrm{Aa}$ & 0,70 & $B$ \\
\hline Média & 0,69 & $\mathrm{a}$ & 0,80 & $\mathrm{a}$ & 0,72 & $\mathrm{a}$ & 0,74 & \\
\hline
\end{tabular}

- C.V. $=20,4 \%$

- DMS Tukey a 5\% (média entre espécies e entre proporções) $=0,14$ e 0.21

- DMS Tukey a 5\% (proporções dentro de espécie e níveis dentro de proporção) =0,36 e 0,31

- Valores das colunas seguidos das mesmas letras maiúsculas e das linhas por letras minúsculas não diferem entre si. 
Tabela 13. Concentração (em porcentagem) de nitrogênio na matéria seca das raízes dos capins gordura, Marandu e Tanzânia-1 sob proporções de $\mathrm{NO}_{3}{ }^{-}$e $\mathrm{NH}_{4}^{+}$em solução nutritiva.

\begin{tabular}{|c|c|c|c|c|c|}
\hline \multirow{2}{*}{$\begin{array}{c}\text { Proporção de } \\
\mathrm{NO}_{3}{ }^{-} / \mathrm{NH}_{4}{ }^{+} \\
(\%)\end{array}$} & \multicolumn{3}{|c|}{ Espécies } & \multirow{2}{*}{\multicolumn{2}{|c|}{ Média }} \\
\hline & Gordura & Marandu & Tanzânia-1 & & \\
\hline $100 / 0$ & 1,15 & 0,97 & 0,85 & 0,99 & A \\
\hline $75 / 25$ & 0,80 & 0,81 & 0,96 & 0,86 & A \\
\hline $75 / 25(-\mathrm{Ca})$ & 0,99 & 1,00 & 1,20 & 1,07 & A \\
\hline $50 / 50$ & 1,02 & 1,30 & 0,74 & 1,02 & A \\
\hline $25 / 75$ & 1,00 & 1,19 & 1,09 & 1,09 & A \\
\hline Média & 0,99 & 1,05 & 0,97 & 1,00 & \\
\hline
\end{tabular}

- C.V. $=26,1 \%$

- DMS Tukey a $5 \%$ (média das espécies e das proporções) $=0,24$ e 0,36

- Valores das colunas seguidos das mesmas letras maiúsculas e das linhas por letras minúsculas não diferem entre si.

\subsubsection{Efeito das proporções de nitrato e amônio sobre a concentração de amônio nos tecidos vegetais}

A concentração de amônio na parte aérea (Tabela 14) teve o maior valor para a proporção 100/0, a qual diferiu significativamente $(\mathrm{P}<0,05)$ daquelas verificadas nas proporções $75 / 25$ em ausência de cálcio e $25 / 75$. Os valores encontrados como mais altas concentrações de amônio nas forrageiras são superiores aos obtidos por SILVEIRA (1981) e ANDRADE (1994), enquanto os demais valores são equivalentes aos encontrados naqueles trabalhos referidos. 
Tabela 14. Concentração de $\mathrm{N}-\mathrm{NH}_{4}{ }^{+}\left(\mathrm{g}\right.$ de N.kg${ }^{-1}$ ) na matéria seca da parte aérea dos capins gordura, Marandu e Tanzânia-1 sob proporções de $\mathrm{NO}_{3}{ }^{-} \mathrm{e}$ $\mathrm{NH}_{4}{ }^{+}$em solução nutritiva.

\begin{tabular}{|c|c|c|c|c|c|c|c|c|}
\hline \multirow{3}{*}{$\begin{array}{c}\begin{array}{c}\text { Proporção de } \\
\mathrm{NO}_{3}^{-} / \mathrm{NH}_{4}^{+} \\
(\%)\end{array} \\
100 / 0\end{array}$} & \multicolumn{6}{|c|}{ Espécies } & \multirow{2}{*}{\multicolumn{2}{|c|}{ Média }} \\
\hline & \multicolumn{2}{|c|}{ Gordura } & \multicolumn{2}{|c|}{ Marandu } & \multicolumn{2}{|c|}{ Tanzânia-1 } & & \\
\hline & 1,15 & $\mathrm{Ab}$ & 1,62 & $\mathrm{Aa}$ & 1,78 & $\mathrm{Aa}$ & 1,52 & A \\
\hline $75 / 25$ & 1,27 & $\mathrm{Aa}$ & 1,36 & $\mathrm{ABa}$ & 1,44 & $\mathrm{BCa}$ & 1,36 & $\mathrm{AB}$ \\
\hline $75 / 25(-\mathrm{Ca})$ & 1,41 & $\mathrm{Aa}$ & 1,35 & $\mathrm{ABa}$ & 1,24 & $\mathrm{Ca}$ & 1,33 & $\mathrm{~B}$ \\
\hline $50 / 50$ & 1,14 & $\mathrm{Ab}$ & 1,39 & $\mathrm{ABa}$ & 1,53 & $\mathrm{ABa}$ & 1,36 & $\mathrm{AB}$ \\
\hline $25 / 75$ & 1,37 & $\mathrm{ABa}$ & 1,22 & $\mathrm{Ba}$ & 1,33 & $\mathrm{BCa}$ & 1,30 & $\mathrm{~B}$ \\
\hline Média & 1,27 & $\mathrm{~b}$ & 1,39 & $\mathrm{a}$ & 1,47 & $\mathrm{a}$ & 1,38 & \\
\hline
\end{tabular}

- DMS Tukey a 5\% (média entre espécies e entre proporções) $=0,11$ e 0,17

- DMS Tukey a $5 \%$ (proporções dentro de espécie e espécies dentro de proporção) = 0,29 e 0,17

- Valores das colunas seguidos das mesmas letras maiúsculas e das linhas por letras minúsculas não diferem entre si.

Para as médias das espécies, o capim-gordura apresentou o menor teor de amônio ( $\mathrm{P}<0,01)$, e os capins Marandu e Tanzânia-1 foram iguais.

Os maiores valores absolutos de $\mathrm{N}_{-} \mathrm{NH}_{4}^{+}$da parte aérea dos capins Tanzânia-1 e Marandu, na proporção 100/0 \% de nitrato e amônio, pode ter sido função do processamento das amostras como sugere PATE (1972), a qual teria provocado degradação de compostos nitrogenados, principalmente amidas, ou ainda elevada degradação durante o processo final de crescimento, o que pode ter ocorrido nesta proporção.

Na proporção $50 / 50 \%$ de nitrato e amônio a parte aérea do capins Tanzânia-1 e Marandu apresentaram mais elevadas concentrações de amônio do que a do capim-gordura, provavelmente indicando menor adaptação à mais alta concentração desta fonte de nitrogênio. 
A concentração de amônio nas folhas novas não apresentou diferença significativa $(\mathrm{P}>0,05)$ entre as proporções de nitrato e amônio mas revelou diferença significativa $(\mathrm{P}<0,05)$ entre as espécies testadas, tendo capimgordura teor menor que as outras espécies. O valor médio da concentração de amônio nas folhas novas foi superior ao encontrado nas raízes, mas foi semelhante a obtida nos colmos + bainhas e inferior à das folhas velhas, o que está de acordo com o relatado por LEWIS et al. (1982), de que o amônio é assimilado principalmente nas raízes.

A concentração de amônio nas folhas velhas apresentou variação significativa para as espécies e para as proporções de nitrato e amônio na solução, conforme apresentado na tabela 16. O teor foi mais elevado no capim-Tanzânia-1 e mais baixo nos capins gordura e Marandu. Para as proporções de nitrato e amônio a mais alta concentração ocorreu na proporção 100/0 . As proporções $75 / 25$ em ausência de cálcio e 25/75 tiveram os menores teores de amônio nas folhas velhas (Tabela 16).

As espécies apresentaram diferentes teores de $\mathrm{N}-\mathrm{NH}_{4}{ }^{+}$, entre as proporções, na matéria seca de folhas velhas $(\mathrm{P}<0,05)$. O capim-gordura obteve o maior valor na proporção $50 / 50$ e 100/0\% de nitrato e amônio para os capins Marandu e Tanzânia-1, tendo sido para esta última forrageira igual a proporção $75 / 25$. Esta diferença fica mais evidente quando se comparam os valores de cada espécie dentro de proporções.

A concentração de amônio nos colmos + bainhas não apresentou variação significativa $(P>0,05)$ quer para as espécies ou para as proporções de nitrato e amônio na solução nutritiva, como apresentado na tabela 17. Entretanto, o desdobramento das interações mostrou diferenças $(P<0,05)$ entre as plantas dentro de cada proporção. Para a proporção $100 / 0 \%$ de nitrato e amônio o capimTanzânia-1 foi superior ao gordura, e esses dois não diferiram do capim-Marandu. Contudo, na proporção 50/50\% o capim-gordura obteve valor inferior aos demais. O efeito de proporções dentro de espécie mostrou para o capim-gordura o inverso do ocorrido com as folhas velhas e tendência semelhante aquela encontrada para o capim-Tanzânia-1. 
Tabela 15. Concentração (em mg N/g) de $\mathrm{N}^{-N_{4}}{ }_{4}^{+}$na matéria seca das folhas novas dos capins gordura, Marandu e Tanzânia-1 sob proporções de $\mathrm{NO}_{3}{ }^{-}$e $\mathrm{NH}_{4}^{+}$em solução nutritiva.

\begin{tabular}{|c|c|c|c|c|c|c|c|c|}
\hline \multirow{3}{*}{$\begin{array}{c}\text { Proporção de } \\
\mathrm{NO}_{3} / \mathrm{NH}_{4}^{+} \\
(\%) \\
100 / 0\end{array}$} & \multicolumn{6}{|c|}{ Espécies } & \multirow{2}{*}{\multicolumn{2}{|c|}{ Média }} \\
\hline & \multicolumn{2}{|c|}{ Gordura } & \multicolumn{2}{|c|}{ Marandu } & \multicolumn{2}{|c|}{ Tanzânia-1 } & & \\
\hline & 1,13 & $b$ & 1,58 & $a$ & 1,38 & $a b$ & 1,37 & A \\
\hline $75 / 25$ & 1,21 & $\mathrm{~b}$ & 1,52 & $\mathrm{a}$ & 1,30 & $a b$ & 1,34 & A \\
\hline $75 / 25(-\mathrm{Ca})$ & 1,33 & $\mathrm{a}$ & 1,33 & $\mathrm{a}$ & 1,45 & $\mathrm{a}$ & 1,37 & A \\
\hline $50 / 50$ & 1,13 & $\mathrm{~b}$ & 1,30 & $\mathrm{~b}$ & 1,62 & $\mathrm{a}$ & 1,35 & $\bar{A}$ \\
\hline $25 / 75$ & 1,35 & $\mathrm{a}$ & 1,27 & $\mathrm{a}$ & 1,17 & $\mathrm{a}$ & 1,26 & $\mathrm{~A}$ \\
\hline Média & 1,23 & $b$ & 1,40 & $\mathrm{a}$ & 1,38 & $\mathrm{a}$ & 1,34 & \\
\hline
\end{tabular}

- C.V. $=9,97 \%$

- DMS Tukey a 5\% (média entre espécies e entre proporções) $=0,12$ e 0,18

- DMS Tukey a 5\% (proporções dentro de espécie e espécies dentro de proporção) = 0,32 e0,27

- Valores das colunas seguidos das mesmas letras maiúsculas e das linhas por letras minúsculas não diferem entre si.

Tabela 16. Cóncentração (em mg N/g) de $\mathrm{N}_{-N_{4}}^{+}$na matéria seca das folhas velhas dos capins gordura, Marandu e Tanzânia-1 sob proporções de $\mathrm{NO}_{3}{ }^{-}$e $\mathrm{NH}_{4}^{+}$em solução nutritiva.

\begin{tabular}{|c|c|c|c|c|c|c|c|c|}
\hline \multirow{2}{*}{$\begin{array}{c}\text { Proporção de } \\
\mathrm{NO}_{3}^{-} / \mathrm{NH}_{4}^{+} \\
(\%)\end{array}$} & \multicolumn{6}{|c|}{ Espécies } & \multirow{2}{*}{\multicolumn{2}{|c|}{ Média }} \\
\hline & \multicolumn{2}{|c|}{ Gordura } & \multicolumn{2}{|c|}{ Marandu } & \multicolumn{2}{|c|}{ Tanzânia-1 } & & \\
\hline $100 / 0$ & 1,28 & $\mathrm{Bb}$ & 1,92 & $\mathrm{Aa}$ & 1,88 & $\mathrm{Aa}$ & 1,69 & $\mathrm{~A}$ \\
\hline $75 / 25$ & 1,28 & $\mathrm{Bb}$ & 1,25 & $\mathrm{Bb}$ & 1,70 & $\mathrm{ABa}$ & 1,41 & $\mathrm{BC}$ \\
\hline $75 / 25(-\mathrm{Ca})$ & 1,23 & $\mathrm{Ba}$ & 1,32 & $\mathrm{Ba}$ & 1,27 & $\mathrm{Ca}$ & 1,27 & $\mathrm{D}$ \\
\hline $50 / 50$ & 1,65 & $\mathrm{Aa}$ & 1,35 & $\mathrm{Bb}$ & 1,53 & $\mathrm{Ba}$ & 1,51 & $\mathrm{~B}$ \\
\hline $25 / 75$ & 1,20 & $\mathrm{Bb}$ & 1,18 & $\mathrm{Bb}$ & 1,52 & $\mathrm{Ba}$ & 1,30 & $\mathrm{CD}$ \\
\hline Média & 1,33 & $\mathrm{~b}$ & 1,40 & $b$ & 1,58 & $\mathrm{a}$ & 1,44 & \\
\hline
\end{tabular}

- C.V. $=6,08 \%$

- DMS Tukey a 5\% (média entre espécies e entre proporções) $=0,08$ e 0,12

- DMS Tukey a 5\% (proporç̃os dentro de espécie e espécies dentro de proporção) =0,21 e 0,18

- Valores das colunas seguidos das mesmas letras maiúsculas e das linhas por letras minúsculas não diferem entre si. 
Tabela 17. Concentração de $\mathrm{N}^{-\mathrm{NH}_{4}}{ }^{+}\left(\mathrm{g}\right.$ de $\mathrm{N} \cdot \mathrm{kg}^{-1}$ ) na matéria seca das colmos e bainhas dos capins gordura, Marandu e Tanzânia-1 sob proporções de $\mathrm{NO}_{3}{ }^{-}$e $\mathrm{NH}_{4}^{+}$em solução nutritiva.

\begin{tabular}{|c|c|c|c|c|c|c|c|c|}
\hline \multirow{3}{*}{$\begin{array}{c}\begin{array}{c}\text { Proporção de } \\
\mathrm{NO}_{3}^{-} / \mathrm{NH}_{4}^{+} \\
(\%)\end{array} \\
100 / 0\end{array}$} & \multicolumn{6}{|c|}{ Espécies } & \multirow{2}{*}{\multicolumn{2}{|c|}{ Média }} \\
\hline & \multicolumn{2}{|c|}{ Gordura } & \multicolumn{2}{|c|}{ Marandu } & \multicolumn{2}{|c|}{ Tanzânia-1 } & & \\
\hline & 1,07 & $\mathrm{ABb}$ & 1,42 & $\mathrm{Aab}$ & 1,85 & $\mathrm{Aa}$ & 1,44 & A \\
\hline $75 / 25$ & 1,28 & $\mathrm{ABa}$ & 1,30 & $\mathrm{Aa}$ & 1,32 & $\mathrm{ABa}$ & 1,30 & A \\
\hline $75 / 25(-\mathrm{Ca})$ & 1,52 & $\mathrm{Aa}$ & 1,40 & $\mathrm{Aa}$ & 1,10 & $\mathrm{Ba}$ & 1,33 & $\mathrm{~A}$ \\
\hline $50 / 50$ & 0,87 & $\mathrm{Bb}$ & 1,48 & $\mathrm{Aa}$ & 1,50 & $\mathrm{ABa}$ &, 128 & $\mathrm{~A}$ \\
\hline $25 / 75$ & 1,47 & $\mathrm{Aa}$ & 1,23 & $\mathrm{Aa}$ & 1,25 & $\mathrm{Ba}$ & 1,32 & $\mathrm{~A}$ \\
\hline Média & 1,24 & $\mathrm{a}$ & 1,37 & $\mathrm{a}$ & 1,40 & $\mathrm{a}$ & 1,34 & \\
\hline
\end{tabular}

- C.V. $=16,95 \%$

- DMS Tukey a $5 \%$ (média entre espécies e entre proporções) $=0,21$ e 0,31

- DMS Tukey a $5 \%$ (proporções dentro de espécie e espécies dentro de proporção) = 0,54 e 0,46

- Valores das colunas seguidos das mesmas letras maiúsculas e das linhas por letras minúsculas não diferem entre si.

$\mathrm{O}$ teor de amônio nas raízes variou significativamente $(\mathrm{P}<0,05)$ somente para as proporções de nitrato e amônio, tendo-se encontrado os maiores valores nos tratamentos com 100/0 e 75/25 \% de nitrato e amônio (Tabela 18). Observou-se uma queda nos valores da concentração de amônio nas raízes à medida que se aumentou a participação do amônio na solução nutritiva. Foram obtidas nas raízes as mais baixas concentrações de amônio nas partes das forrageiras, o que está de acordo com o obtido por COX \& REISENAUER (1973) e LEWIS et al. (1992).

Apesar de não ter havido efeito significativo e geral para espécies, o desdobramento das interações mostra que o capim-gordura apresentou valores maiores $(\mathrm{P}<0,05)$ que $\mathrm{o}$ capim-Tanzânia-1 nas proporções 75/25 e 
50/50\% de nitrato e amônio, e superior ao capim-Marandu, somente nesta última proporção. O efeito das proporções dentro de espécie revelou uma redução gradativa com o aumento da participação de amônio na solução nutritiva, para os capins Marandu e gordura, com redução para esta última forrageira ao se retirar o cálcio da solução. Para esta interação o capim-Tanzânia-1 apresentou valor superior apenas para a maior proporção de nitrato, o que difere dos resultados de SILVEIRA (1981) e ANDRADE (1994).

Tabela 18. Concentração $\mathrm{N}-\mathrm{NH}_{4}{ }^{+}$(g de $\mathrm{N} \mathrm{kg}^{-1}$ ) na matéria seca das raízes dos capins gordura, Marandu e Tanzânia-1 sob proporções de $\mathrm{NO}_{3}{ }^{-}$e $\mathrm{NH}_{4}{ }^{+}$ em solução nutritiva.

\begin{tabular}{|c|c|c|c|c|c|c|c|c|}
\hline \multirow{3}{*}{$\begin{array}{c}\text { Proporção de } \\
\mathrm{NO}_{3}^{-} / \mathrm{NH}_{4}^{+} \\
(\%)\end{array}$} & \multicolumn{6}{|c|}{ Espécies } & \multirow{2}{*}{\multicolumn{2}{|c|}{ Média }} \\
\hline & \multicolumn{2}{|c|}{ Gordura } & \multicolumn{2}{|c|}{ Marandu } & \multicolumn{2}{|c|}{ Tanzânia-1 } & & \\
\hline & 1,55 & $\mathrm{Aa}$ & 1,47 & $\mathrm{Aa}$ & 1,65 & $\mathrm{Aa}$ & 1,56 & A \\
\hline $75 / 25$ & 1,52 & $\mathrm{Aa}$ & 1,42 & Aab & 1,10 & $\mathrm{Bb}$ & 1,34 & $\mathrm{AB}$ \\
\hline $75 / 25(-\mathrm{Ca})$ & 1,07 & $\mathrm{BCa}$ & 1,43 & $\mathrm{Aa}$ & 1,20 & $\mathrm{Ba}$ & 1,23 & $\mathrm{BC}$ \\
\hline $50 / 50$ & 1,30 & $\mathrm{ABa}$ & 0,90 & $\mathrm{Bb}$ & 0,90 & $\mathrm{Bb}$ & 1,03 & $\mathrm{CD}$ \\
\hline $25 / 75$ & 0,65 & $\mathrm{Ca}$ & 0,80 & $\mathrm{Ba}$ & 0,90 & $\mathrm{Ba}$ & 0,78 & $\mathrm{D}$ \\
\hline Média & 1,22 & $\mathrm{a}$ & 1,20 & $\mathrm{a}$ & 1,15 & $\mathrm{a}$ & 1,19 & \\
\hline
\end{tabular}

- C.V. $=15,72 \%$

- DMS Tukey a 5\% (média entre espécies e entre proporções) $=0,17$ e 0,26

- DMS Tukey a 5\% (proporções dentro de espécie e espécies dentro de proporção) $=0,45$ e 0,38

- Valores das colunas seguidos das mesmas letras maiúsculas e das linhas por letras minúsculas não diferem entre si.

\subsubsection{Efeito das proporções de nitrato e amônio sobre a concentração de nitrato nos tecidos vegetais}


A concentração de nitrato na parte aérea apresentou variação significativa $(\mathrm{P}<0,05)$ para as proporções de nitrato e amônio (Tabela 19). A parte aérea colhida na proporção 100/0 teve concentração igual a da proporção $75 / 25$ e superior a 75/25 \% (-Ca), as quais apresentaram concentrações de nitrato mais elevadas do que as proporções 50/50 e 25/75. Estes resultados concordam com os de SILVEIRA (1981) e ANDRADE (1994) para o capim-colonião, embora sejam as concentrações obtidas neste experimento relativamente inferiores às reportadas naqueles trabalhos. Também, FERNANDES \& FREIRE (1976) e FERNANDES \& FREIRE (1978) relataram valores superiores aos obtidos neste trabalho. Os teores de nitrato considerados tóxicos para animais por SZODFRIDT \& VARGA (1989) são superiores aos valores obtidos neste experimento.

Tabela 19. Concentração de $\mathrm{N}_{-} \mathrm{NO}_{3}{ }^{-}\left(\mathrm{g}\right.$ de N$\left.\cdot \mathrm{kg}^{-1}\right)$ na matéria seca da parte aérea dos capins gordura, Marandu e Tanzânia-1 sob proporções de $\mathrm{NO}_{3}{ }^{-} \mathrm{e}$ $\mathrm{NH}_{4}^{+}$em solução nutritiva.

\begin{tabular}{|c|c|c|c|c|c|c|c|c|}
\hline \multirow{3}{*}{$\begin{array}{c}\begin{array}{c}\text { Proporção de } \\
\mathrm{NO}_{3}{ }^{*} / \mathrm{NH}_{4}^{+} \\
(\%)\end{array} \\
100 / 0\end{array}$} & \multicolumn{6}{|c|}{ Espécies } & \multirow{2}{*}{\multicolumn{2}{|c|}{ Média }} \\
\hline & \multicolumn{2}{|c|}{ Gordura } & \multicolumn{2}{|c|}{ Marandu } & \multicolumn{2}{|c|}{ Tanzânia-1 } & & \\
\hline & 1,90 & $\mathrm{Aa}$ & 1,87 & $\mathrm{Aa}$ & 1,65 & $\mathrm{ABa}$ & 1,81 & $\mathrm{~A}$ \\
\hline $75 / 25$ & 1,49 & $\mathrm{ABa}$ & 1,58 & $\mathrm{ABa}$ & 1,72 & $\mathrm{Aa}$ & 1,60 & $\mathrm{AB}$ \\
\hline $75 / 25(-\mathrm{Ca})$ & 1,89 & $\mathrm{Aa}$ & 1,40 & $\mathrm{BCb}$ & 1,31 & $\mathrm{ABCb}$ & 1,53 & B \\
\hline $50 / 50$ & 0,99 & $\mathrm{Ca}$ & 1,01 & $\mathrm{Ca}$ & 1,14 & $\mathrm{Ba}$ & 1,05 & $\mathrm{C}$ \\
\hline $25 / 75$ & 1,30 & $\mathrm{BCa}$ & 1,16 & $\mathrm{BCa}$ & 1,19 & $\mathrm{BCa}$ & 1,20 & $\mathrm{BC}$ \\
\hline Média & 1,51 & $\mathrm{a}$ & 1,40 & $\mathrm{a}$ & 1,40 & $\mathrm{a}$ & 1,44 & \\
\hline
\end{tabular}

- C.V. $=13,43 \%$

- DMS Tukey a 5\% (média entre espécies e entre proporções) $=0,18$ e 0,27

- DMS Tukey a 5\% (proporções dentro de espécie e espécies dentro de proporção) $=0,46$ e 0,39

- Valores das colunas seguidos das mesmas letras maiúsculas e das linhas por letras minúsculas não diferem entre si. 
Na proporção de 100/0 de nitrato e amônio o capim-gordura teve maior concentração de nitrato $(\mathrm{P}<0,05)$ do que os capins Tanzânia-1 e Marandu. Para as duas proporções com maior participação de amônio na solução nutritiva não houve diferença significativa $(P>0,05)$ entre as três espécies, provavelmente devido ao efeito prejudicial dessa fonte de nitrogênio em proporções elevadas na solução nutritiva, além do fato de o nitrato ter menor participação nestas duas soluções.

A concentração de nitrato das folhas novas apresentou variação significativa $(P<0,05)$ para proporções de nitrato e amônio na solução nutritiva. Foram obtidos semelhantes teores de nitrato nas folhas novas quando comparadas as proporções 100/0, 75/25 (-Ca) e 75/25 \% de nitrato e amônio. Por outro lado, as médias das proporções 50/50 e 25/75 não diferiram significativamente ( $\mathrm{P}$ > $0,05)$ entre si e tiveram as mais baixas concentrações de nitrato nas folhas novas, embora tenha ocorrido igualdade entre todas as proporções para os capins gordura e Marandu (Tabela 20). Os valores absolutos de nitrato nas folhas novas do capim-Marandu foram sempre inferiores aos das demais forrageiras, exceto para a maiorparticipação de amônio na solução, na qual superou o capim-Tanzânia-1 , apesar de as três forrageiras apresentarem valores estatiscamente iguais $(\mathrm{P}>$ 0,05). Esta observação permite sugerir a possibilidade de uma maior assimilação do capim-Marandu neste estágio final de desenvolvimento.

Para as folhas velhas, a concentração de nitrato mostrou-se muito próxima daquela encontrada nas folhas novas (médias gerais de 1,49 e 1,46 g de $\mathrm{N}-\mathrm{NO}_{3}{ }^{-} \cdot \mathrm{kg}^{-1}$ ), provavelmente devido ao acúmulo de nitrato em organelas celulares, no denominado "pool citoplasmático", o qual não induz a atividade da redutase do nitrato (FERNANDES \& FREIRE, 1976 e FERNANDES \& ROSSIELO,1986).

Houve variação significativa $(\mathrm{P}<0,05)$ entre as espécies para a concentração de nitrato nas folhas velhas (Tabela 21). O capim-Tanzânia-1 mostrou o mais baixo teor, que por sua vez não foi estatisticamente $(P>0,05)$ 
diferente daquele do capim-gordura, provavelmente em função da precocidade de desenvolvimento dos capins Tanzânia-1 e gordura em relação ao capim-Marandu, com um maior aproveitamento inicial, principalmente para o Panicum.

Tabela 20. Concentração de $\mathrm{N}-\mathrm{NO}_{3}{ }^{-}\left(\mathrm{g}_{\text {de N}} \mathrm{kg}^{-1}\right)$ na matéria seca das folhas novas dos capins gordura, Marandu e Tanzânia-1 sob proporções de $\mathrm{NO}_{3}{ }^{-} \mathrm{e}$ $\mathrm{NH}_{4}^{+}$em solução nutritiva.

\begin{tabular}{|c|c|c|c|c|c|c|c|c|}
\hline \multirow{3}{*}{$\begin{array}{c}\begin{array}{c}\text { Proporção de } \\
\mathrm{NO}_{3}^{-} / \mathrm{NH}_{4}^{+} \\
(\%)\end{array} \\
100 / 0\end{array}$} & \multicolumn{6}{|c|}{ Espécies } & \multirow{2}{*}{\multicolumn{2}{|c|}{ Média }} \\
\hline & \multicolumn{2}{|c|}{ Gordura } & \multicolumn{2}{|c|}{ Marandu } & \multicolumn{2}{|c|}{ Tanzânia-1 } & & \\
\hline & 1,73 & $\mathrm{Aa}$ & 1,53 & $\mathrm{Aa}$ & 1,77 & $\mathrm{ABa}$ & 1,68 & $\mathrm{~A}$ \\
\hline $75 / 25$ & 1,80 & $\mathrm{Aa}$ & 1,63 & $\mathrm{Aa}$ & 1,82 & $\mathrm{ABa}$ & 1,75 & $\mathrm{~A}$ \\
\hline $75 / 25(-\mathrm{Ca})$ & 1,97 & $\mathrm{Aa}$ & 1,07 & $\mathrm{Aa}$ & 1,93 & $\mathrm{Aa}$ & 1,66 & $\mathrm{~A}$ \\
\hline $50 / 50$ & 1,20 & $\mathrm{Aa}$ & 0,90 & $\mathrm{Aa}$ & 1,10 & $\mathrm{ABa}$ & 1,08 & $\mathrm{~B}$ \\
\hline $25 / 75$ & 1,25 & $\mathrm{Aa}$ & 1,17 & $\mathrm{Aa}$ & 1,02 & $\mathrm{Ba}$ & 1,14 & $\mathrm{~B}$ \\
\hline Média & 1,59 & $\mathrm{a}$ & 1,53 & $\mathrm{a}$ & 1,52 & $\mathrm{a}$ & 1,56 & \\
\hline
\end{tabular}

- DMS Tukey a $5 \%$ (média entre espécies e entre proporções) $=0,33$ e 0,49

- DMS Tukey a 5\% (proporções dentro de espécie e espécies dentro de proporção) = 0,73 e 0,86

- Valores das colunas seguidos das mesmas letras maiúsculas e das linhas por letras minúsculas não diferem entre si.

As proporções de nitrato e amônio na solução nutritiva influenciaram significativamente $(\mathrm{P}<0,05)$ os teores de nitrato nas folhas velhas dos capins. A exemplo do constatado com as folhas novas, as proporções 100/0, $75 / 25$ (-Ca) e 75/25 \% de nitrato e amônio tiveram concentrações similares de nitrato nas folhas velhas. Também, as proporções 50/50 e 25/75 foram estatisticamente iguais.

Obteve-se interação entre os fatores para a concentração de nitrato nas folhas velhas, com os capins gordura e Marandu superiores ao Tanzânia-1 $(\mathrm{P}<0,05)$, apenas na proporção em ausência de cálcio, o que 
provavelmente pode ser explicado pela elevada atividade da redutase do nitrato (Tabela 24) desta última forrageira em ausência de cálcio, que teve concentração diferente apenas da proporção com $100 \%$ de nitrato. Esta superioridade dentro das proporções teve comportamento diferente para as outras forrageiras, sendo para o capim-gordura a proporção 75/25 e para o capim-Marandu as proporções com $100 \%$ de nitrato e em ausência de cálcio.

Tabela 21. Concentração de $\mathrm{N}_{-} \mathrm{NO}_{3}^{-}\left(\mathrm{g}\right.$ de N.kg$\left.{ }^{-1}\right)$ na matéria seca das folhas velhas dos capins gordura, Marandu e Tanzânia-1 sob proporções de $\mathrm{NO}_{3}{ }^{-}$e $\mathrm{NH}_{4}^{+}$em solução nutritiva

\begin{tabular}{|c|c|c|c|c|c|c|c|c|}
\hline \multirow{3}{*}{$\begin{array}{c}\begin{array}{c}\text { Proporção de } \\
\mathrm{NO}_{3}{ }^{-} / \mathrm{NH}_{4}{ }^{+} \\
(\%)\end{array} \\
100 / 0\end{array}$} & \multicolumn{6}{|c|}{ Espécies } & \multirow{2}{*}{\multicolumn{2}{|c|}{ Média }} \\
\hline & \multicolumn{2}{|c|}{ Gordura } & \multicolumn{2}{|c|}{ Marandu } & \multicolumn{2}{|c|}{ Tanzânia-1 } & & \\
\hline & 1,60 & $\mathrm{ABa}$ & 1,87 & $\mathrm{Aa}$ & 1,70 & $\mathrm{Aa}$ & 1,74 & A \\
\hline $75 / 25$ & 1,80 & $\mathrm{Aa}$ & 1,65 & $\mathrm{ABa}$ & 1,50 & $\mathrm{ABa}$ & 1,65 & $\mathrm{~A}$ \\
\hline 75/25 (-Ca) & 1,80 & $\mathrm{Aa}$ & 1,92 & $\mathrm{Aa}$ & 1,03 & $\mathrm{Bb}$ & 1,58 & $\mathrm{AB}$ \\
\hline $50 / 50$ & 1,10 & $\mathrm{Ba}$ & 1,27 & $\mathrm{Ba}$ & 1,18 & $\mathrm{ABa}$ & 1,18 & $\mathrm{C}$ \\
\hline $25 / 75$ & 1,40 & $\mathrm{ABa}$ & 1,22 & $\mathrm{Ba}$ & 1,20 & $\mathrm{ABa}$ & 1,27 & $\mathrm{BC}$ \\
\hline Média & 1,55 & $a b$ & 1,58 & $\mathrm{a}$ & 1,33 & $\mathrm{~b}$ & 1,49 & \\
\hline
\end{tabular}

- C.V. $=16,54 \%$

- DMS Tukey a 5\% (média entre espécies e entre proporções) $=0,23$ e 0,34

- DMS Tukey a $5 \%$ (proporções dentro de espécie e espécies dentro de proporção) $=0,59$ e 0.50

- Valores das colunas seguidos das mesmas letras maiúsculas e das linhas por letras minúsculas não diferem entre si.

A relação entre a atividade da redutase do nitrato e a participação de nitrato na solução nutritiva pode ter determinado diferenças na concentração de nitrato das folhas velhas, considerando que estas folhas velhas correspondiam a constituição nitrogenada da forragem por ocasião da determinação da atividade enzimática. Desta forma, pode-se relacionar a menor concentração de nitrato das 
folhas velhas do capim-gordura na proporção $100 \%$ de nitrato, com a maior atividade enzimática nesta proporção. Contudo, a mesma relação não pode ser feita para o capim-Marandu, porque a maior atividade enzimática na proporção $100 \%$ de nitrato corresponde ao maior acúmulo de nitrato nas folhas velhas.

Houve variação significativa $(P<0,05)$ na concentração de nitrato nos colmos + bainhas entre as proporções de nitrato e amônio (Tabela 22), tendo-se encontrado superioridade para o tratamento 100/0, o qual não diferiu estatisticamente do 75/25 (-Ca). Os tratamentos com 50 e $25 \%$ de nitrato na solução nutritiva resultaram em semelhantes teores de nitrato nos colmos + bainhas, os quais foram significativamente $(\mathrm{P}<0,05)$ mais baixos do que nas proporções 100/0 e 75/25 (-Ca). Quanto às espécies estudadas não se detectou mudança significativa $(P>0,05)$ nesta concentração (Tabela 22).

$\mathrm{Na}$ interação entre proporções e espécies forrageiras para concentração de nitrato dos colmos $+\mid$ bainhas, obteve-se os maiores valores na proporção $100 \%$ de nitrato para os capins gordura e Marandu, superiores a todos os valores de concentração de nitrato encontrados neste trabalho. Esta elevada concentração indica a possibilidade de acúmulo nesta fração da planta para os capins gordura e Marandu. Contudo, para o capim-Tanzânia-1 estes valores foram muito semelhantes entre as proporções. Entretanto, os menores valores foram atingidos com a utilização de partes iguais de nitrato e amônio.

A concentração de nitrato nas raízes variou significativamente $(P$ $<0,05)$ entre as proporções de nitrato e amônio e entre as gramíneas testadas. Essa concentração foi mais elevada na proporção 100/0 do que na 75/25 (com e sem cálcio), tendo ambas as proporções resultado em concentrações de nitrato mais elevadas que nas proporções de 50/50 e 25/75 (Tabela 23).

Foi detectada diferença significativa $(\mathrm{P}<0,05)$ entre as espécies quanto ao teor de nitrato nas raizes, tendo os capins gordura e Marandu maiores concentrações do que o capim-Tanzânia-1. Isto pode evidenciar para os capins de maior acúmulo, que as raízes sejam órgão de estocagem do nitrato como proposto 
para a grama-batatais por BENDIX et al. (1980) e IMPITHUKSA \& BLUE (1985). Contudo, os valores de nitrato nas raízes foram muito inferiores aos das outras partes da planta.

Tabela 22. Concentração de $\mathrm{N}-\mathrm{NO}_{3}{ }^{-}\left(\mathrm{g}\right.$ de N$\left.\cdot \mathrm{kg}^{-1}\right)$ na matéria seca dos colmos + bainhas dos capins gordura, Marandu e Tanzânia-1 sob proporções de $\mathrm{NO}_{3}{ }^{-}$e $\mathrm{NH}_{4}^{+}$em solução nutritiva.

\begin{tabular}{|c|c|c|c|c|c|c|c|c|}
\hline \multirow{3}{*}{$\begin{array}{c}\begin{array}{c}\text { Proporção de } \\
\mathrm{NO}_{3}^{-} / \mathrm{NH}_{4}^{+} \\
(\%)\end{array} \\
100 / 0\end{array}$} & \multicolumn{6}{|c|}{ Espécies } & \multirow{2}{*}{\multicolumn{2}{|c|}{ Média }} \\
\hline & \multicolumn{2}{|c|}{ Gordura } & \multicolumn{2}{|c|}{ Marandu } & \multicolumn{2}{|c|}{ Tanzânia-1 } & & \\
\hline & 2,03 & $A a b$ & 2,10 & $\overline{\mathrm{Aa}}$ & 1,57 & $\mathrm{ABb}$ & 1,90 & $\bar{A}$ \\
\hline $75 / 25$ & 1,25 & $\mathrm{Bb}$ & 1,53 & $\mathrm{ABab}$ & 1,77 & $\mathrm{Aa}$ & 1,52 & $\mathrm{BC}$ \\
\hline $75 / 25(-\mathrm{Ca})$ & 1,92 & $\mathrm{Aa}$ & 1,10 & $\mathrm{BCb}$ & 1,67 & $\mathrm{ABa}$ & 1,57 & $\mathrm{AB}$ \\
\hline $50 / 50$ & 0,87 & $\mathrm{Ba}$ & 0,93 & $\mathrm{Ca}$ & 1,13 & $\mathrm{Ba}$ & 0,98 & $\mathrm{D}$ \\
\hline $25 / 75$ & 1,25 & $\mathrm{Ba}$ & 1,10 & $\mathrm{BCa}$ & 1,25 & $\mathrm{ABa}$ & 1,20 & $\mathrm{CD}$ \\
\hline Média & 1,46 & $\mathrm{a}$ & 1,36 & $\mathrm{a}$ & 1,48 & $\mathrm{a}$ & 1,43 & \\
\hline
\end{tabular}

- DMS Tukey a $5 \%$ (média entre espécies e entre proporções) $=0,22$ e 0,33

- DMS Tukey a $5 \%$ (proporções dentro de espécie e espécies dentro de proporção) $=0,58$ e 0,49

- Valores das colunas seguidos das mesmas letras maiúsculas e das linhas por letras minúsculas não diferem entre si.

Observa-se que a redução na concentração de nitrato nas raízes, com a diminuição do teor de nitrato na solução nutritiva ocorreu de forma diferente entre as forrageiras. Para o capim-Tanzânia-1 ocorreu a partir da proporção $75 / 25$, e em ausência de cálcio e 50/50\% de nitrato e amônio, respectivamente, para os capins gordura e Marandu. 
Tabela 23. Concentração de $\mathrm{N}-\mathrm{NO}_{3}{ }^{-}\left(\mathrm{g}\right.$ de N.kg$\left.{ }^{-1}\right)$ na matéria seca das raízes dos capins gordura, Marandu e Tanzânia-1 sob proporções de $\mathrm{NO}_{3}{ }^{-} \mathrm{e} \mathrm{NH}_{4}{ }^{+}$ em solução nutritiva.

\begin{tabular}{|c|c|c|c|c|c|c|c|c|}
\hline \multirow{3}{*}{$\begin{array}{c}\begin{array}{c}\text { Proporção de } \\
\mathrm{NO}_{3}^{-} / \mathrm{NH}_{4}^{+} \\
(\%)\end{array} \\
100 / 0\end{array}$} & \multicolumn{6}{|c|}{ Espécies } & \multirow{2}{*}{\multicolumn{2}{|c|}{ Média }} \\
\hline & \multicolumn{2}{|c|}{ Gordura } & \multicolumn{2}{|c|}{ Marandu } & \multicolumn{2}{|c|}{ Tanzânia-1 } & & \\
\hline & 1,52 & $\mathrm{Aa}$ & 1,18 & $\mathrm{Ab}$ & 1,38 & Aab & 1,36 & A \\
\hline $75 / 25$ & 1,32 & $\mathrm{Aa}$ & 1,02 & $\mathrm{Aa}$ & 0,67 & $\mathrm{Bb}$ & 1,00 & $\mathrm{~B}$ \\
\hline $75 / 25(-\mathrm{Ca})$ & 0,67 & $\mathrm{Bb}$ & 1,10 & $\mathrm{Aa}$ & 0,60 & $\mathrm{Bb}$ & 0,79 & $\mathrm{BC}$ \\
\hline $50 / 50$ & 0,53 & $\mathrm{Ba}$ & 0,53 & $\mathrm{Ba}$ & 0,50 & $\mathrm{Ba}$ & 0,52 & $\mathrm{D}$ \\
\hline $25 / 75$ & 0,63 & $\mathrm{Ba}$ & 0,60 & $\mathrm{Ba}$ & 0,53 & $\mathrm{Ba}$ & 0,59 & $\mathrm{CD}$ \\
\hline Média & 0,93 & $\mathrm{a}$ & 0,89 & $\mathrm{a}$ & 0,74 & b & 0,85 & \\
\hline
\end{tabular}

- C.V. $=18,16 \%$

- DMS Tukey a 5\% (média entre espécies e entre proporções) $=0,14$ e 0,21

- DMS Tukey a 5\% (proporções dentro de espécie e espécies dentro de proporção) $=0,37$ e 0,31

- Valores das colunas seguidos das mesmas letras maiúsculas e das linhas por letras minúsculas não diferem entre si.

\subsubsection{Efeito das proporções de nitrato e amônio sobre a atividade da redutase do nitrato}

Nos resultados da atividade da redutase do nitrato (Tabela 24), encontrou-se variação significativa entre as proporções de nitrato e amônio, onde a proporção $100 / 0$ foi significativamente $(\mathrm{P}<0,05)$ superior à proporção de $25 / 75$, entretanto foram iguais as demais proporções.

Houve significância $(P<0,01)$ para a interação entre proporção de nitrato e amônio e espécie forrageira. $O$ desdobramento dessa interação mostrou o capim-Tanzânia-1 tendo atividades similares nas proporções 100/0 e 75/25 (com ou sem cálcio), contudo as atividades nas proporções 50/50 e 25/75 foram significativamente $(\mathrm{P}<0,05)$ inferiores aquela da proporção 75/25 (-Ca). 
Os capins gordura e Marandu apresentaram desempenhos semelhantes dentro de todas as proporções de nitrato e amônio na solução. Encontrou-se diferença significativa $(P<0,05)$ dentro da proporção 75/25 (-Ca) entre o capim-Tanzânia-1 e os capins gordura e Marandu, com o primeiro mostrando atividade mais elevada.

Tabela 24. Atividade da redutase do nitrato $\left(\mu\right.$ moles de $\mathrm{NO}_{2} /$ grama de material fresco / hora) dos capins gordura, Marandu e Tanzânia-1 sob proporções de $\mathrm{NO}_{3}{ }^{-}$e $\mathrm{NH}_{4}{ }^{+}$em solução nutritiva.

\begin{tabular}{|c|c|c|c|c|c|c|c|c|}
\hline \multirow{3}{*}{$\begin{array}{c}\begin{array}{c}\text { Proporção de } \\
\mathrm{NO}_{3}{ }^{-} / \mathrm{NH}_{4}^{+} \\
(\%)\end{array} \\
100 / 0\end{array}$} & \multicolumn{6}{|c|}{ Espécies } & \multirow{2}{*}{\multicolumn{2}{|c|}{ Média }} \\
\hline & \multicolumn{2}{|c|}{ Gordura } & \multicolumn{2}{|c|}{ Marandu } & \multicolumn{2}{|c|}{ Tanzânia-1 } & & \\
\hline & 0,090 & $\mathrm{Aa}$ & 0,100 & $\mathrm{Aa}$ & 0,120 & $\mathrm{ABa}$ & 0,103 & $\mathrm{~A}$ \\
\hline $75 / 25$ & 0,070 & $\mathrm{Aa}$ & 0,050 & $\mathrm{Aa}$ & 0,080 & $\mathrm{ABa}$ & 0,070 & $\mathrm{AB}$ \\
\hline 75/25 (-Ca) & 0,05 & $\mathrm{Ab}$ & 0,060 & $\mathrm{Ab}$ & 0,150 & $\mathrm{Aa}$ & 0,090 & $\mathrm{AB}$ \\
\hline $50 / 50$ & 0,038 & $\mathrm{Aa}$ & 0,025 & $\mathrm{Aa}$ & 0,033 & $\mathrm{Ba}$ & 0,090 & $\mathrm{AB}$ \\
\hline $25 / 75$ & 0,052 & $\mathrm{Aa}$ & 0,046 & $\mathrm{Aa}$ & 0,027 & $\mathrm{Ba}$ & 0,040 & $\mathrm{~B}$ \\
\hline Média & 0,060 & $\mathrm{a}$ & 0,056 & $\mathrm{a}$ & 0,082 & $\mathrm{a}$ & 0,066 & \\
\hline
\end{tabular}

- C.V. $=55,3 \%$

- DMS Tukey a 5\% (média entre espécies e entre proporções) $=0,06$ e 0,09

- DMS Tukey a 5\% (proporções dentro de espécie e espécies dentro de proporção) = 0,09 e 0,07

- Valores das colunas seguidos das mesmas letras maiúsculas e das linhas por letras minúsculas não diferem entre si.

Os resultados do presente experimento revelaram atividades enzimáticas mais baixas que as obtidos por FERNANDES \& FREIRE (1976) para Brachiaria sp.. Por seu turno, ANDRADE (1994) obteve resultados em que o aumento da participação do amônio até 50\% refletiu em mais elevada atividade da redutase do nitrato, o que não foi verificado no presente experimento. 
A queda da atividade da redutase do nitrato para a proporções 25/75 e 50/50 de nitrato e amônio pode ser resultado da diminuição da concentração externa e/ou interna de nitrato, uma vez que este ânion é um dos fatores que controlam a atividade da redutase do nitrato (SRIVASTAVA, 1980; CAMPBELL, 1988; LA HABA et al., 1988).

SRIVASTAVA (1980) ressaltou que a ausência do íon cálcio pode provocar a redução da atividade da redutase, fato que não se constatou no presente estudo. De outra forma, foi verificada a mais elevada atividade absoluta da enzima com o capim-Tanzânia-1, na ausência de cálcio na solução nutritiva.

\subsubsection{Efeito das proporções de nitrato e amônio sobre a concentração de fósforo nos tecidos vegetais}

A concentração de fósforo na parte aérea (Tabela 25), variou significativamente $(\mathrm{P}<0,05)$ entre as gramíneas, com os capins Tanzânia-1 e Marandu apresentando concentrações superiores a do capim-gordura. Também, para as proporções de nitrato e amônio, foi detectada variação significativa ( $\mathrm{P}<$ 0,05), sendo que o tratamento 75/25 (-Ca) mostrou a mais elevada concentração de fósforo na parte aérea. De forma contrária na proporção com $25 \%$ de amônio foram obtidas as mais baixas concentrações de fósforo, possivelmente, devido ao estímulo provocado por baixas concentrações de amônio, que aumentam o consumo e assimilação de nitrato como ressaltaram FERNANDES et al. (1978). Provavelmente, este fato é o resultado da necessidade da planta conseguir o balanço ácido-base (KIRKBY, 1968), devido a maior absorção de amônio, que faz a extrusão de $\mathrm{H}^{+}$, e que reduz a dissociação dos radicais carboxílicos da parede celular, reduzindo portanto a sua densidade de carga negativa e aumentando a velocidade de difusão dos ânions através dos microporos da parede celular (LUIS et al., 1983; FERNANDES et al., 1984 e FERNANDES \& 
ROSSIELO, 1986). Este mecanismo é mais evidente para o capim-Tanzânia-1, que apresentou os mais altos valores $(\mathrm{P}<0,05)$ quando não se usou cálcio na solução nutritiva.

Tabela 25. Concentração de fósforo (em porcentagem) da matéria seca da parte aérea dos capins gordura, Marandu e Tanzânia-1 sob proporções de $\mathrm{NO}_{3}{ }^{-}$e $\mathrm{NH}_{4}^{+}$em solução nutritiva.

\begin{tabular}{|c|c|c|c|c|c|c|c|c|}
\hline \multirow{3}{*}{$\begin{array}{c}\text { Proporção de } \\
\mathrm{NO}_{3}^{-} / \mathrm{NH}_{4}^{+} \\
(\%)\end{array}$} & \multicolumn{6}{|c|}{ Espécies } & \multirow{2}{*}{\multicolumn{2}{|c|}{ Média }} \\
\hline & \multicolumn{2}{|c|}{ Gordura } & \multicolumn{2}{|c|}{ Marandu } & \multicolumn{2}{|c|}{ Tanzânia-1 } & & \\
\hline & 0,13 & $\mathrm{Ba}$ & 0,09 & $\mathrm{Ba}$ & 0,13 & $\mathrm{Ba}$ & 0,13 & $\mathrm{~B}$ \\
\hline $75 / 25$ & 0,09 & $\mathrm{Da}$ & 0,11 & $\mathrm{Ca}$ & 0,10 & $\mathrm{Ca}$ & 0,11 & $\mathrm{C}$ \\
\hline 75/25(-Ca) & 0,16 & $\mathrm{Ab}$ & 0,18 & $\mathrm{Ab}$ & 0,20 & $\mathrm{Aa}$ & 0,18 & A \\
\hline $50 / 50$ & 0,10 & $\mathrm{CDb}$ & 0,13 & $\mathrm{BCa}$ & 0,13 & $\mathrm{Ba}$ & 0,12 & $\mathrm{~B}$ \\
\hline $25 / 75$ & 0,13 & $\mathrm{BCa}$ & 0,14 & $\mathrm{Ba}$ & 0,13 & $\mathrm{Ba}$ & 0,13 & $\mathrm{~B}$ \\
\hline Média & 0,12 & $\mathrm{~b}$ & 0,14 & $\mathrm{a}$ & 0,14 & $\mathrm{a}$ & 0,13 & \\
\hline
\end{tabular}

- C.V. $=8,14 \%$

- DMS Tukey a 5\% (média entre espécies e entre proporções) $=0,01$ e 0,015

- DMS Tukey a $\%$ (proporções dentro de espécie e espécies dentro de proporção) $=0,03$ e 0,02

- Valores das colunas seguidos das mesmas letras maiúsculas e das linhas por letras minúsculas não diferem entre si.

As concentrações de fósforo nas folhas novas, folhas velhas, colmos + bainhas, e raízes constam respectivamente nas Tabelas 26, 27, 28 e 29. Os valores médios desses teores, em ordem decrescente, foram obtidos para folhas novas, colmos + bainhas, folhas velhas e raizes.

Algumas particularidades podem ser observadas nestas concentrações de fósforo nas forrageiras estudadas, nas partes da planta. $\mathrm{Na}$ proporção que se obteve a maior concentração de fósforo (75/25 \% em ausência de cálcio) o capim-gordura apresentou maior concentração que as demais plantas em folhas novas, e em particular nesta parte da planta, para todas as proporções, esta gramínea foi superior. Contudo, nos colmos + bainhas o capim-Tanzânia-1 
em ausência de cálcio, teve a mais elevada concentração observada, que foi superior a das demais forrageiras, além de apresentar os mais altos valores em comparação com as demais plantas, em todas as proporções, para esta parte da planta. Estas observações podem indicar diferentes órgãos de concentração de fósforo para estas duas forrageiras independente de maior ou menor absorção de fósforo.

Tabela 26. Concentração de fósforo (em porcentagem) da matéria seca das folhas novas dos capins gordura, Marandu e Tanzânia-1 sob proporções de $\mathrm{NO}_{3}^{-}{ }^{-} \mathrm{NH}_{4}^{+}$em solução nutritiva.

\begin{tabular}{|c|c|c|c|c|c|}
\hline \multirow{2}{*}{$\begin{array}{c}\text { Proporção de } \\
\mathrm{NO}_{3}^{-} / \mathrm{NH}_{4}^{+} \\
(\%)\end{array}$} & \multicolumn{3}{|c|}{ Espécies } & \multirow{2}{*}{\multicolumn{2}{|c|}{ Média }} \\
\hline & Gordura & Marandu & Tanzânia-1 & & \\
\hline $100 / 0$ & 0,19 & 0,17 & 0,17 & 0,18 & $\mathrm{AB}$ \\
\hline $75 / 25$ & 0,16 &, 012 & 0,12 & 0,13 & $\mathrm{C}$ \\
\hline $75 / 25(-\mathrm{Ca})$ & 0,21 & 0,17 & 0,19 & 0,19 & $\mathrm{~A}$ \\
\hline $50 / 50$ & 0,14 & 0,13 & 0,13 & 0,14 & $\mathrm{C}$ \\
\hline $25 / 75$ & 0,18 & 0,14 & 0,15 & 0,16 & $\mathrm{~B}$ \\
\hline Média & 0,18 & 0,15 & 0,15 & 0,16 & \\
\hline
\end{tabular}

- C.V. $=8,7 \%$

- DMS Tukey a 5\% (média entre espécies e entre proporções) $=0,013$ e 0,019

- Valores das colunas seguidos das mesmas letras maiúsculas e das linhas por letras minúsculas não diferem entre si. 
Tabela 27. Concentração de fósforo (em porcentagem) da matéria seca das folhas velhas dos capins gordura, Marandu e Tanzânia-1 sob proporções de $\mathrm{NO}_{3}^{-}$e $\mathrm{NH}_{4}^{+}$em solução nutritiva.

\begin{tabular}{|c|c|c|c|c|c|}
\hline \multirow{2}{*}{$\begin{array}{c}\text { Proporção de } \\
\mathrm{NO}_{3}^{-} / \mathrm{NH}_{4}^{+} \\
(\%)\end{array}$} & \multicolumn{3}{|c|}{ Espécies } & \multirow{2}{*}{\multicolumn{2}{|c|}{ Média }} \\
\hline & Gordura & Marandu & Tanzânia-1 & & \\
\hline $100 / 0$ & 0,10 & 0,10 & 0,09 & 0,10 & $\mathrm{BC}$ \\
\hline $75 / 25$ & 0,06 & 0,07 & 0,07 & 0,07 & $\mathrm{D}$ \\
\hline 75/25 (-Ca) & 0,13 &, 016 & 0,17 & 0,15 & A \\
\hline $50 / 50$ & 0,07 & 0,09 & 0,09 & 0,087 & $\mathrm{CD}$ \\
\hline $25 / 75$ & 0,10 & 0,11 & 0,10 & 0,11 & $\mathrm{~B}$ \\
\hline Média & 0,09 & 0,11 & 0,10 & 0,10 & \\
\hline
\end{tabular}

- C.V. $=14,1 \%$

- DMS Tukey a $5 \%$ (média entre espécies e entre proporções) $=0,0$ le 0,02

- Valores das colunas seguidos das mesmas letras maiúsculas e das linhas por letras minúsculas não diferem entre si.

Tabela 28. Concentração de fósforo (em porcentagem) da matéria seca dos colmos + bainhas dos capins gordura, Marandu e Tanzânia-1 sob proporções de $\mathrm{NO}_{3}^{-}$e $\mathrm{NH}_{4}^{+}$em solução nutritiva.

\begin{tabular}{|c|c|c|c|c|c|c|c|c|}
\hline \multirow{3}{*}{$\begin{array}{c}\begin{array}{c}\text { Proporção de } \\
\mathrm{NO}_{3}^{-} \mathrm{NH}_{4}^{+} \\
(\%)\end{array} \\
100 / 0\end{array}$} & \multicolumn{6}{|c|}{ Espécies } & \multirow{2}{*}{\multicolumn{2}{|c|}{ Média }} \\
\hline & \multicolumn{2}{|c|}{ Gordura } & \multicolumn{2}{|c|}{ Marandu } & \multicolumn{2}{|c|}{ Tanzânia-1 } & & \\
\hline & 0,12 & $\mathrm{Bb}$ & 0,12 & $\mathrm{BCa}$ & 0,17 & $\mathrm{Ba}$ & 0,14 & B \\
\hline $75 / 25$ & 0,08 & $\mathrm{Cb}$ & 0,10 & $\mathrm{Bab}$ & 0,11 & $\mathrm{Ca}$ & 0,09 & $\mathrm{C}$ \\
\hline $75 / 25(-\mathrm{Ca})$ & 0,16 & Ac & 0,19 & $\mathrm{Ab}$ & 0,26 & $\mathrm{Aa}$ & 0,20 & $\mathrm{~A}$ \\
\hline $50 / 50$ & 0,10 & $\mathrm{BCb}$ & 0,14 & $\mathrm{Ba}$ & 0,15 & $\mathrm{Ba}$ & 0,13 & B \\
\hline $25 / 75$ & 0,11 & $\mathrm{BCb}$ & 0,14 & $\mathrm{Ba}$ & 0,15 & $\mathrm{Ba}$ & 0,13 & $\mathrm{~B}$ \\
\hline Média & 0,11 & $\mathrm{c}$ & 0,14 & $\mathrm{~b}$ & 0,17 & $\mathrm{a}$ & 0,14 & \\
\hline
\end{tabular}

- C.V. $=9,7 \%$

- DMS Tukey a 5\% (média entre espécies e entre proporções) $=0,01$ e 0,02

- DMS Tukey a 5\% (proporções dentro de espécie e espécies dentro de proporção) $=0,07$ e 0,06

- Valores das colunas seguidos das mesmas letras maiúsculas e das linhas por letras minúsculas não diferem entre si. 
Tabela 29. Concentração de fósforo (em porcentagem) da matéria seca das raízes dos capins gordura, Marandu e Tanzânia-1 sob proporções de $\mathrm{NO}_{3}{ }^{-}$e $\mathrm{NH}_{4}^{+}$em solução nutritiva.

\begin{tabular}{|c|c|c|c|c|c|}
\hline \multirow{2}{*}{$\begin{array}{c}\text { Proporção de } \\
\mathrm{NO}_{3}{ }^{-} / \mathrm{NH}_{4}{ }^{+} \\
(\%) \\
\end{array}$} & \multicolumn{3}{|c|}{ Espécies } & \multirow{2}{*}{\multicolumn{2}{|c|}{ Média }} \\
\hline & Gordura & Marandu & Tanzânia-1 & & \\
\hline $100 / 0$ & 0,11 & 0,10 & 0,08 & 0,098 & $\mathrm{AB}$ \\
\hline $75 / 25$ & 0,07 & 0,08 & 0,08 & 0,077 & B \\
\hline $75 / 25(-\mathrm{Ca})$ & 0,13 & 0,10 & 0,12 & 0,12 & $\mathrm{~A}$ \\
\hline $50 / 50$ & 0,096 & 0,10 & 0,07 & 0,09 & B \\
\hline $25 / 75$ & 0,09 & 0,09 & 0,07 & 0,08 & $B$ \\
\hline Média & 0,10 & 0,09 & 0,09 & 0,09 & \\
\hline
\end{tabular}

- C.V. $=21,3 \%$

- DMS Tukey a 5\% (média entre espécies e entre proporções) $=0,05$ e 0,03

- Valores das colunas seguidos das mesmas letras maiúsculas e das linhas por letras minúsculas não diferem entre si.

\subsubsection{Efeito das proporções de nitrato e amônio sobre a concentração de potássio nos tecidos vegetais}

A concentração de potássio na parte aérea (Tabela 30) apresentou variação significativa $(\mathrm{P}<0,05)$ para as proporções de nitrato e amônio, tendo o tratamento 75/25 (-Ca) mostrado teor mais elevado que todos os demais tratamentos. Os tratamentos com as mais elevadas participações de nitrato, em presença de cálcio estiveram entre as mais baixas concentrações de potássio, o que se contrapõe aos resultados mencionados por FERNANDES \& ROSSIELO (1986) e verificados por COX \& REISENAUER (1973) e LUISI et al. (1983).

Foi detectada diferença significativa $(\mathrm{P}<0,05)$ na comparação entre as médias das concentrações de potássio para cada espécie, com valor inferior para o capim-gordura (Tabela 30). O desdobramento da interação entre espécies e proporções de nitrato e amônio mostrou significância $(P<0,05)$ nas 
comparações, porém em qualquer delas, o que se esperava (mais elevada concentração de potássio no tratamento com apenas nitrato) não ocorreu para os três capins. Ao se comparar os capins Marandu e Tanzânia-1, não se constatou diferença significativa $(\mathrm{P}>0,05)$ entre as proporções de nitrato e amônio na solução nutritiva, contudo o capim-gordura apresentou concentrações inferiores nas proporções com 75 e $25 \%$ de nitrato.

Tabela 30 Concentração de potássio (em porcentagem) da matéria seca da parte aérea dos capins gordura, Marandu e Tanzânia-1 sob proporções de $\mathrm{NO}_{3}^{-}$e $\mathrm{NH}_{4}^{+}$em solução nutritiva,

\begin{tabular}{|c|c|c|c|c|c|c|c|c|}
\hline \multirow{3}{*}{$\begin{array}{c}\begin{array}{c}\text { Proporção de } \\
\mathrm{NO}_{3}^{-} / \mathrm{NH}_{4}^{+} \\
(\%)\end{array} \\
100 / 0\end{array}$} & \multicolumn{6}{|c|}{ Espécies } & \multirow{2}{*}{\multicolumn{2}{|c|}{ Média }} \\
\hline & \multicolumn{2}{|c|}{ Gordura } & \multicolumn{2}{|c|}{ Marandu } & \multicolumn{2}{|c|}{ Tanzânia-1 } & & \\
\hline & 1,71 & $\mathrm{BCa}$ & 1,74 & $\mathrm{Ba}$ & 1,70 & $\mathrm{Ba}$ & 1,72 & $\mathrm{C}$ \\
\hline $75 / 25$ & 1,58 & $\mathrm{BCb}$ & 2,10 & $\mathrm{ABa}$ & 2,12 & $\mathrm{ABa}$ & 1,92 & $\mathrm{BC}$ \\
\hline $75 / 25(-\mathrm{Ca})$ & 2,24 & $\mathrm{Aa}$ & 2,29 & $\mathrm{Aa}$ & 2,50 & $\mathrm{Aa}$ & 2,34 & $\mathrm{~A}$ \\
\hline $50 / 50$ & 1,37 & $\mathrm{Cb}$ & 2,00 & $\mathrm{ABa}$ & 2,04 & $\mathrm{Ba}$ & 1,80 & $\mathrm{BC}$ \\
\hline $25 / 75$ & 1,93 & $\mathrm{ABa}$ & 2,16 & $\mathrm{ABa}$ & 2,03 & $\mathrm{Ba}$ & 2,04 & $\mathrm{~B}$ \\
\hline Média & 1,77 & $\mathrm{~b}$ & 2,05 & $\mathrm{a}$ & 2,08 & $\mathrm{a}$ & 1,96 & \\
\hline
\end{tabular}

- DMS Tukey a 5\% (média entre espécies e entre proporções) $=0,17$ e 0,26

- DMS Tukey a $5 \%$ (proporções dentro de espécie e espécies dentro de proporção) $=0,44$ e 0,38

- Valores das colunas seguidos das mesmas letras maiúsculas e das linhas por letras minúsculas não diferem entre si.

As concentrações de potássio nas folhas novas, folhas velhas, colmos + bainhas, e raízes são mostradas, respectivamente nas tabelas 31, 32, 33 e 34. Foram observados valores médios de potássio, em ordem decrescente, para colmos + bainhas, folhas novas, folhas velhas e raízes, o que concorda em parte com as informações de mobilidade deste nutriente ( KIRKBY \& MENGEL, 1987). 
Tabela 31. Concentração de potássio (em porcentagem) da matéria seca das folhas novas dos capins gordura, Marandu e Tanzânia-1 sob proporções de $\mathrm{NO}_{3}{ }^{-}$e $\mathrm{NH}_{4}^{+}$em solução nutritiva.

\begin{tabular}{|c|c|c|c|c|c|}
\hline \multirow{2}{*}{$\begin{array}{c}\text { Proporção de } \\
\mathrm{NO}_{3}^{-} \mathrm{NH}_{4}^{+} \\
(\%) \\
\end{array}$} & \multicolumn{3}{|c|}{ Espécies } & \multirow{2}{*}{\multicolumn{2}{|c|}{ Média }} \\
\hline & Gordura & Marandu & Tanzânia-1 & & \\
\hline $100 / 0$ & 1,84 & 1,84 & 1,55 & 1,74 & $\mathrm{AB}$ \\
\hline $75 / 25$ & 1,58 & 1,58 & 1,53 & 1,57 & $\mathrm{~B}$ \\
\hline 75/25 (-Ca) & 2,02 & 2,01 & 1,68 & 1,90 & $\mathrm{AB}$ \\
\hline $50 / 50$ & 1,53 & 2,04 & 1,66 & 1,74 & $\mathrm{AB}$ \\
\hline $25 / 75$ & 1,94 & 2,47 & 1,71 & 2,04 & $\mathrm{~A}$ \\
\hline Média & 1,78 & 2,00 & 1,63 & 1,80 & \\
\hline
\end{tabular}

- C.V. $=16,49 \%$

- DMS Tukey a $5 \%$ (média entre espécies e entre proporções) $=0,27$ e0,41

- Valores das colunas seguidos das mesmas letras maiúsculas e das linhas por letras minúsculas não diferem entre si.

Tabela 32. Concentração de potássio (em porcentagem) da matéria seca das folhas velhas dos capins gordura, Marandu e Tanzânia-1 sob proporções de $\mathrm{NO}_{3}{ }^{-}$e $\mathrm{NH}_{4}^{+}$em solução nutritiva.

\begin{tabular}{|c|c|c|c|c|c|}
\hline \multirow{2}{*}{$\begin{array}{c}\text { Proporção de } \\
\mathrm{NO}_{3}^{-} \mathrm{NH}_{4}^{+} \\
(\%)\end{array}$} & \multicolumn{3}{|c|}{ Espécies } & \multirow{2}{*}{\multicolumn{2}{|c|}{ Média }} \\
\hline & Gordura & Marandu & Tanzânia-1 & & \\
\hline $100 / 0$ & 1,43 & 1,96 & 1,45 & 1,61 & $\mathrm{Bc}$ \\
\hline $75 / 25$ & 1,43 & 1,43 & 1,61 & 1,49 & $\mathrm{C}$ \\
\hline $75 / 25(-\mathrm{Ca})$ & 1,84 & 2,62 & 2,12 & 2,20 & $\mathrm{~A}$ \\
\hline $50 / 50$ & 0,94 & 2,12 & 1,74 & 1,59 & $\mathrm{BC}$ \\
\hline $25 / 75$ & 1,73 & 2,42 & 1,68 & 1,95 & $\mathrm{AB}$ \\
\hline Média & 1,47 & 2,11 & 1,72 & 1,77 & \\
\hline
\end{tabular}

- C.V. $=14,69 \%$

- DMS Tukey a 5\% (média entre espécies e entre proporções) = o,24 e 0,36

- Valores das colunas seguidos das mesmas letras maiúsculas e das linhas por letras minúsculas não diferem entre si. 
Tabela 33. Concentração de potássio (em porcentagem) da matéria seca dos colmos + bainhas dos capins gordura, Marandu e Tanzânia-1 sob proporções de $\mathrm{NO}_{3}^{-}{ }^{-} \mathrm{NH}_{4}^{+}$em solução nutritiva.

\begin{tabular}{|c|c|c|c|c|c|}
\hline \multirow{2}{*}{$\begin{array}{c}\text { Proporção de } \\
\mathrm{NO}_{3}{ }^{-} / \mathrm{NH}_{4}{ }^{+} \\
(\%)\end{array}$} & \multicolumn{3}{|c|}{ Espécies } & \multirow{2}{*}{\multicolumn{2}{|c|}{ Média }} \\
\hline & Gordura & Marandu & Tanzânia-1 & & \\
\hline $100 / 0$ & 1,86 & 1,51 & 2,14 & 1,83 & B \\
\hline $75 / 25$ & 1,63 & 1,63 & 2,86 & 2,04 & $B$ \\
\hline $75 / 25(-\mathrm{Ca})$ & 2,53 & 2,17 & 3,62 & 2,77 & $\mathrm{~A}$ \\
\hline $50 / 50$ & 1,56 & 1,89 & 2,65 & 2,03 & $\mathrm{~B}$ \\
\hline $25 / 75$ & 2,02 & 1,84 & 2,55 & 2,13 & B \\
\hline Média & 1,92 & 1,81 & 2,77 & 2,16 & \\
\hline
\end{tabular}

- C.V. $=15,51$

- DMS Tukey a 5\% (média entre espécies e entre proporções) $=0,3$ e 0,46

- Valores das colunas seguidos das mesmas letras maiúsculas e das linhas por letras minúsculas não diferem entre si.

Tabela 34. Concentração de potássio (em porcentagem) da matéria seca das raízes dos capins gordura, Marandu e Tanzânia-1 sob proporções de $\mathrm{NO}_{3}^{-} \mathrm{e}$ $\mathrm{NH}_{4}^{+}$em solução nutritiva.

\begin{tabular}{|c|c|c|c|c|c|}
\hline \multirow{2}{*}{$\begin{array}{c}\text { Proporção de } \\
\mathrm{NO}_{3}^{-} / \mathrm{NH}_{4}^{+} \\
(\%) \\
\end{array}$} & \multicolumn{3}{|c|}{ Espécies } & \multirow{2}{*}{\multicolumn{2}{|c|}{ Média }} \\
\hline & Gordura & Marandu & Tanzânia-1 & & \\
\hline $100 / 0$ & 0,84 & 0,59 & 0,54 & 0,66 & $\mathrm{~B}$ \\
\hline $75 / 25$ & 0,71 & 0,71 & 0,87 & 0,76 & $\mathrm{~B}$ \\
\hline $75 / 25(-\mathrm{Ca})$ & 0,92 & 0,69 & 0,95 & 0,85 & $\mathrm{AB}$ \\
\hline $50 / 50$ & 1,57 & 1,17 & 0,97 & 1,24 & $\mathrm{~A}$ \\
\hline $25 / 75$ & 1,04 & 1,20 & 0,66 & 0,97 & $\mathrm{AB}$ \\
\hline Média & 1,02 & 0,87 & 0,80 & 0,90 & \\
\hline
\end{tabular}

- C.V. $=35,40$

- DMS Tukey a 5\% média entre espécies e entre proporções) $=0,29$ e 0,44

- Valores das colunas seguidos das mesmas letras maiúsculas e das linhas por letras minúsculas não diferem entre si. 


\subsubsection{Efeito das proporções de nitrato e amônio sobre a concentração de cálcio nos tecidos vegetais}

A concentração de cálcio na parte aérea variou significativamente $(\mathrm{P}<0,05)$ entre as proporções de nitrato e amônio e entre as espécies estudadas (Tabela 35). A concentração mais elevada foi observada no tratamento que só continha nitrato na solução, o qual se diferenciou de todos os outros tratamentos. A proporção 75/25 (-Ca) resultou nos mais baixos teores de cálcio na parte aérea. Estes resultados estão de acordo com os obtidos por KIRKBY (1968); BLAIR et al., (1970) e COX \& REISENAUER (1973), e com os mencionados por FERNANDES \& ROSSIELO (1986).

Tabela 35. Concentração de cálcio (em porcentagem) na matéria seca da parte aérea dos capins gordura, Marandu e Tanzânia-1 sob proporções de $\mathrm{NO}_{3}{ }^{-}$e $\mathrm{NH}_{4}^{+}$em solução nutritiva.

\begin{tabular}{|c|c|c|c|c|c|c|c|c|}
\hline \multirow{3}{*}{$\begin{array}{c}\text { Proporção de } \\
\mathrm{NO}_{3}^{-} / \mathrm{NH}_{4}^{+} \\
(\%)\end{array}$} & \multicolumn{6}{|c|}{ Espécies } & \multirow{2}{*}{\multicolumn{2}{|c|}{ Média }} \\
\hline & \multicolumn{2}{|c|}{ Gordura } & \multicolumn{2}{|c|}{ Marandu } & \multicolumn{2}{|c|}{ Tanzânia-1 } & & \\
\hline & 0,25 & Ac & 0,58 & $\mathrm{Aa}$ & 0,46 & $\mathrm{Aa}$ & 0,43 & A \\
\hline $75 / 25$ & 0,19 & $\mathrm{ABb}$ & 0,35 & $\mathrm{Ba}$ & 0,29 & $\mathrm{Ca}$ & 0,28 & $\mathrm{~B}$ \\
\hline $75 / 25(-\mathrm{Ca})$ & 0,12 & $\mathrm{Ba}$ & 0,20 & $\mathrm{Ca}$ & 0,14 & $\mathrm{D}$ & 0,15 & C \\
\hline $50 / 50$ & 0,15 & $\mathrm{ABb}$ & 0,34 & $\mathrm{Ba}$ & 0,34 & $\mathrm{BC}$ & 0,28 & $\mathrm{~B}$ \\
\hline $25 / 75$ & 0,23 & $\mathrm{ABb}$ & 0,33 & $\mathrm{Ba}$ & 0,42 & $\mathrm{AB}$ & 0,32 & B \\
\hline Média & 0,19 & $b$ & 0,36 & $\mathrm{a}$ & 0,33 & $\mathrm{a}$ & 0,29 & \\
\hline
\end{tabular}

Na comparação das forrageiras, quanto à concentração de cálcio na parte aérea, verificou-se que o capim-gordura apresentou o mais baixo valor, o 
qual diferiu daqueles dos capins Marandu e Tanzânia-1, que foram iguais entre si. A interação entre as forrageiras e as proporções de nitrato e amônio foi significativa $(\mathrm{P}<0,05)$. Para o capim-Marandu o tratamento com maior concentração de nitrato na solução nitidamente teve mais elevada concentração de cálcio na parte aérea, o que não se verificou para os capins Tanzânia-1 e gordura.

As concentrações de cálcio nas folhas novas, folhas velhas, colmos + bainhas, e raízes são mostradas respectivamente nas tabelas $36,37,38$ e 39. As concentrações médias de cálcio, em ordem decrescente, que ocorreram nas folhas velhas, raízes, folhas novas e colmos + bainhas, confirmando a pouca mobilidade deste nutriente na planta (MALAVOLTA, 1980 e MENGEL \& KIRKBY, 1987).

A concentração de cálcio nas folhas velhas do capim-Marandu foi superior as das demais plantas, para todas as proporções, indicando a menor remobilização nesta espécie ou o maior consumo de cálcio durante o período inicial de crescimento.

Tabela 36. Concentração de cálcio (em porcentagem) na matéria seca das folhas novas dos capins gordura, Marandu e Tanzânia-1 sob proporções de $\mathrm{NO}_{3}^{-}$e $\mathrm{NH}_{4}^{+}$em solução nutritiva.

\begin{tabular}{|c|c|c|c|c|c|}
\hline \multirow{2}{*}{$\begin{array}{c}\text { Proporção de } \\
\mathrm{NO}_{3}^{-} / \mathrm{NH}_{4}^{+} \\
(\%)\end{array}$} & \multicolumn{3}{|c|}{ Espécies } & \multirow{2}{*}{\multicolumn{2}{|c|}{ Média }} \\
\hline & Gordura & Marandu & Tanzânia-1 & & \\
\hline $100 / 0$ & 0,19 & 0,31 & 0,34 & 0,28 & $\mathrm{~A}$ \\
\hline $75 / 25$ & 0,23 & 0,26 & 0,21 & 0,23 & $\mathrm{AB}$ \\
\hline $75 / 25(-\mathrm{Ca})$ & 0,09 & 0,10 & 0,10 & 0,10 & $\mathrm{C}$ \\
\hline $50 / 50$ & 0,13 & 0,27 & 0,26 & 0,22 & $\mathrm{~B}$ \\
\hline $25 / 75$ & 0,23 & 0,32 & 0,28 & 0,28 & $\mathrm{~A}$ \\
\hline Média & 0,18 & 0,25 & 0,24 & 0,22 & \\
\hline
\end{tabular}

- C.V. $=17,01$

- DMS Tukey a 5\% (média entre espécies e entre proporções) $=0,03$ e 0,05

- Valores das colunas seguidos das mesmas letras maiúsculas e das linhas por letras minúsculas não diferem entre si. 
Tabela 37. Concentração de cálcio (em porcentagem) na matéria seca das folhas velhas dos capins gordura, Marandu e Tanzânia-1 sob proporções de $\mathrm{NO}_{3}{ }^{-}$e $\mathrm{NH}_{4}^{+}$em solução nutritiva.

\begin{tabular}{|c|c|c|c|c|c|c|c|c|}
\hline \multirow{3}{*}{$\begin{array}{c}\begin{array}{c}\text { Proporção de } \\
\mathrm{NO}_{3}^{-} \mathrm{NH}_{4}^{+} \\
(\%)\end{array} \\
100 / 0\end{array}$} & \multicolumn{6}{|c|}{ Espécies } & \multirow{2}{*}{\multicolumn{2}{|c|}{ Média }} \\
\hline & \multicolumn{2}{|c|}{ Gordura } & \multicolumn{2}{|c|}{ Marandu } & \multicolumn{2}{|c|}{ Tanzânia-1 } & & \\
\hline & 0,47 & $\mathrm{Ab}$ & 1,31 & $\mathrm{Aa}$ & 0,55 & $\mathrm{Ab}$ & 0,78 & A \\
\hline $75 / 25$ & 0,38 & $\mathrm{Ab}$ & 0,77 & $\mathrm{Ba}$ & 0,42 & $\mathrm{ABb}$ & 0,52 & B \\
\hline $75 / 25(-\mathrm{Ca})$ & 0,25 & $\mathrm{Aa}$ & 0,32 & $\mathrm{Ca}$ & 0,14 & $\mathrm{Ba}$ & 0,24 & $\mathrm{C}$ \\
\hline $50 / 50$ & 0,30 & $\mathrm{Ab}$ & 0,74 & $\mathrm{Ba}$ & 0,51 & $\mathrm{ABab}$ & 0,52 & B \\
\hline $25 / 75$ & 0,45 & $\mathrm{Aa}$ & 0,44 & $\mathrm{BCa}$ & 0,62 & $\mathrm{Aa}$ & 0,50 & B \\
\hline Média & 0,37 & b & 0,71 & $\mathrm{a}$ & 0,45 & b & 0,51 & \\
\hline
\end{tabular}

- DMS Tukey a 5\% (média entre espécies e entre proporções) $=0,16$ e 0,24

- DMS Tukey a $5 \%$ (proporções dentro de espécie e espécies dentro de proporção) $=0,41$ e 0,35

- Valores das colunas seguidos das mesmas letras maiúsculas e das linhas por letras minúsculas não diferem entre si.

Tabela 38. Concentração de cálcio (em porcentagem) na matéria seca dos colmos + bainhas dos capins gordura, Marandu e Tanzânia-1 sob proporções de $\mathrm{NO}_{3}^{-}$e $\mathrm{NH}_{4}^{+}$em solução nutritiva.

\begin{tabular}{|c|c|c|c|c|c|c|c|c|}
\hline \multirow{2}{*}{$\begin{array}{c}\text { Proporção de } \\
\mathrm{NO}_{3}^{-} / \mathrm{NH}_{4}^{+} \\
(\%) \\
\end{array}$} & \multicolumn{6}{|c|}{ Espécies } & \multirow{2}{*}{\multicolumn{2}{|c|}{ Média }} \\
\hline & \multicolumn{2}{|c|}{ Gordura } & \multicolumn{2}{|c|}{ Marandu } & \multicolumn{2}{|c|}{ Tanzânia-1 } & & \\
\hline $100 / 0$ & 0,16 & $\mathrm{Ac}$ & 0,27 & $\mathrm{Ab}$ & 0,40 & $\mathrm{Aa}$ & 0,28 & $\mathrm{~A}$ \\
\hline $75 / 25$ & 0,11 & $\mathrm{ABb}$ & 0,22 & $\mathrm{ABCa}$ & 0,22 & $\mathrm{Ca}$ & 0,18 & $\mathrm{C}$ \\
\hline $75 / 25(-\mathrm{Ca})$ & 0,06 & $\mathrm{Bb}$ & 0,16 & $\mathrm{Ca}$ & 0,16 & $\mathrm{Ca}$ & 0,12 & $\mathrm{D}$ \\
\hline $50 / 50$ & 0,07 & $\mathrm{Bb}$ & 0,19 & $\mathrm{BCa}$ & 0,19 & $\mathrm{Ca}$ & 0,15 & $\mathrm{CD}$ \\
\hline $25 / 75$ & 0,12 & $\mathrm{ABb}$ & 0,26 & $\mathrm{ABa}$ & 0,29 & $\mathrm{Ba}$ & 0,23 & $\mathrm{~B}$ \\
\hline Média & 0,11 & $\mathrm{c}$ & 0,22 & $\mathrm{~b}$ & 0,25 & $\mathrm{a}$ & 0,19 & \\
\hline
\end{tabular}

- DMS Tukey a $5 \%$ (média entre espécies e entre proporções) $=0,03$ e 0,05

- DMS Tukey a $\%$ (proporções dentro de espécie e espécies dentro de proporção) $=0,08$ e 0,07

- Valores das colunas seguidos das mesmas letras maiúsculas e das linhas por letras minúsculas não diferem entre si. 
Tabela 39. Concentração de cálcio (em porcentagem) na matéria seca das raízes dos capins gordura, Marandu e Tanzânia-1 sob proporções de $\mathrm{NO}_{3}^{-}$e $\mathrm{NH}_{4}^{+}$em solução nutritiva.

\begin{tabular}{|c|c|c|c|c|c|}
\hline \multirow{2}{*}{$\begin{array}{c}\text { Proporção de } \\
\mathrm{NO}_{3}^{-} / \mathrm{NH}_{4}^{+} \\
(\%)\end{array}$} & \multicolumn{3}{|c|}{ Espécies } & \multirow{2}{*}{\multicolumn{2}{|c|}{ Média }} \\
\hline & Gordura & Marandu & Tanzânia-1 & & \\
\hline $100 / 0$ & 0,46 & 0,43 & 0,40 & 0,43 & A \\
\hline $75 / 25$ & 0,34 & 0,33 & 0,31 & 0,33 & B \\
\hline $75 / 25(-\mathrm{Ca})$ & 0,19 & 0,16 & 0,16 & 0,17 & C \\
\hline $50 / 50$ & 0,29 & 0,29 & 0,27 & 0,28 & B \\
\hline $25 / 75$ & 0,35 & 0,27 & 0,29 & 0,31 & B \\
\hline Média & 0,32 & 0,30 & 0,29 & 0,30 & \\
\hline
\end{tabular}

- C.V. $=14,6$

- DMS Tukey a 5\% (média entre espécies e entre proporções) $=0,04$ e 0,06

- Valores das colunas seguidos das mesmas letras maiúsculas e das linhas por letras minúsculas não diferem entre si.

\subsubsection{Efeito das proporções de nitrato $e$ amônio sobre a concentração de magnésio dos tecidos vegetais}

A concentração de magnésio na parte aérea apresentou variação significativa $(\mathrm{P}<0,05)$ entre as proporções de nitrato e amônio na solução e as espécies estudadas (Tabela 40). A proporção 75/25 \% de nitrato e amônio (-Ca) apresentou a mais baixa concentração de magnésio na parte aérea, o que está de acordo com o coeficiente de correlação entre cálcio e magnésio obtido por ARROYO-AGUILÚ \& COWARD-LORD (1974), como ficou evidente para as raízes (Tabela 44). De outra forma, as mais elevadas concentrações foram obtidas nos tratamentos com $50 \%$ ou mais de nitrato na solução, em presença de cálcio. Estes resultados não concordam com os obtidos por KIRKBY (1969) e BLAIR et al. (1970). Contudo aqueles relatados por COX \& REISENAUER (1973) 
mostram que mantendo o nível de nitrato em $200 \mu$ moles/litro e aumentando o nível de amônio, foram obtidos aumentos na taxa de absorção de magnésio e de cálcio até a quantidade de 50 micromoles de amônio/litro. Talvez este fato possa explicar as concentrações de magnésio obtidas no presente experimento.

Tabela 40. Concentração de magnésio (em porcentagem) na matéria seca da parte aérea dos capins gordura, Marandu e Tanzânia-1 sob proporções de $\mathrm{NO}_{3}^{-}$e $\mathrm{NH}_{4}^{+}$em solução nutritiva.

\begin{tabular}{|c|c|c|c|c|c|c|c|c|}
\hline \multirow{2}{*}{$\begin{array}{c}\text { Proporção de } \\
\mathrm{NO}_{3}{ }^{-} \mathrm{NH}_{4}^{+} \\
(\%)\end{array}$} & \multicolumn{6}{|c|}{ Espécies } & \multirow{2}{*}{\multicolumn{2}{|c|}{ Média }} \\
\hline & \multicolumn{2}{|c|}{ Gordura } & \multicolumn{2}{|c|}{ Marandu } & \multicolumn{2}{|c|}{ Tanzânia-1 } & & \\
\hline $100 / 0$ & 0,22 & Ac & 0,31 & $\mathrm{Ba}$ & 0,26 & $\mathrm{Ab}$ & 0,27 & A \\
\hline $75 / 25$ & 0,19 & $\mathrm{ABc}$ & 0,31 & $\mathrm{Ba}$ & 0,26 & $\mathrm{Ab}$ & 0,25 & $\mathrm{AB}$ \\
\hline $75 / 25(-\mathrm{Ca})$ & 0,15 & $\mathrm{Bb}$ & 0,21 & $\mathrm{Ca}$ & 0,16 & $\mathrm{Bb}$ & 0,17 & $\bar{C}$ \\
\hline $50 / 50$ & 0,19 & $\mathrm{ABc}$ & 0,37 & $\mathrm{Aa}$ & 0,28 & $\mathrm{Ab}$ & 0,28 & A \\
\hline $25 / 75$ & 0,19 & $\mathrm{ABb}$ & 0,24 & $\mathrm{Ca}$ & 0,25 & $\mathrm{Aa}$ & 0,23 & $\mathrm{~B}$ \\
\hline Média & 0,19 & $\mathrm{c}$ & 0,29 & $\mathrm{a}$ & 0,24 & $\mathrm{~b}$ & 0,19 & \\
\hline
\end{tabular}

- DMS Tukey a $5 \%$ (média entre espécies e entre proporções) $=0,02$ e 0,03

- DMS Tukey a $5 \%$ (proporções dentro de espécie e espécies de proporção) $=0.05$ e 0,03

- Valores das colunas seguidos das mesmas letras maiúsculas e das linhas por letras minúsculas não diferem entre si.

O capim-Marandu evidenciou o efeito do amônio na solução sobre a absorção de magnésio na proporção $25 / 75$, além do tratamento sem cálcio. O capim-gordura mostrou a mais baixa concentração de magnésio entre as três forrageiras, entretanto não evidenciou expressivas diferenças entre as proporções de nitrato e amônio, exceto no tratamento sem cálcio. O capim-Tanzânia-1, apresentou a mais baixa concentração de magnésio no tratamento 75/25 (-Ca), a qual diferiu da verificada nas demais proporções testadas.

As concentrações de magnésio obedeceram a ordem decrescente nas folhas velhas, colmos + bainhas, folhas novas, e raizes, e estão apresentadas, respectivamente, nas tabelas 41 a 44 . 
Tabela 41. Concentração de magnésio (em porcentagem) na matéria seca das folhas novas dos capins gordura, Marandu e Tanzânia-1 sob proporções de $\mathrm{NO}_{3}{ }^{-}$e $\mathrm{NH}_{4}^{+}$em solução nutritiva.

\begin{tabular}{|c|c|c|c|c|c|c|c|c|}
\hline \multirow{3}{*}{$\begin{array}{c}\begin{array}{c}\text { Proporção de } \\
\mathrm{NO}_{3}^{-} \mathrm{NH}_{4}^{+} \\
(\%)\end{array} \\
100 / 0\end{array}$} & \multicolumn{6}{|c|}{ Espécies } & \multirow{2}{*}{\multicolumn{2}{|c|}{ Média }} \\
\hline & \multicolumn{2}{|c|}{ Gordura } & \multicolumn{2}{|c|}{ Marandu } & \multicolumn{2}{|c|}{ Tanzânia-1 } & & \\
\hline & 0,17 & $\mathrm{Aa}$ & 0,17 & $\mathrm{BCa}$ & 0,15 & $\mathrm{Aa}$ & 0,16 & $\mathrm{~B}$ \\
\hline $75 / 25$ & 0,18 & $\mathrm{Aa}$ & 0,22 & $\mathrm{Ba}$ & 0,17 & $\mathrm{Aa}$ & 0,19 & B \\
\hline $75 / 25(-\mathrm{Ca})$ & 0,16 & $\mathrm{Aa}$ & 0,12 & $\mathrm{Ca}$ & 0,14 & $\mathrm{Aa}$ & 0,13 & $\mathrm{C}$ \\
\hline $50 / 50$ & 0,19 & $\mathrm{Ab}$ & 0,30 & $\mathrm{Aa}$ & 0,20 & $\mathrm{Ab}$ & 0,23 & A \\
\hline $25 / 75$ & 0,17 & $\mathrm{Aa}$ & 0,19 & $\mathrm{Ba}$ & 0,17 & $\mathrm{Aa}$ & 0,18 & $\mathrm{~B}$ \\
\hline Média & 0,17 & $b$ & 0,20 & $\mathrm{a}$ & 0,17 & $b$ & 0,18 & \\
\hline \multicolumn{9}{|c|}{$\begin{array}{l}\text { C.V. }=16,0 \% \\
\text { DMS Tukey a } 5 \% \text { (média entre espécies e entre proporções) }=0,03 \text { e } 0,04\end{array}$} \\
\hline
\end{tabular}

Tabela 42. Concentração de magnésio (em porcentagem) na matéria seca das folhas velhas dos capins gordura, Marandu e Tanzânia-1 sob proporções de $\mathrm{NO}_{3}{ }^{-}$e $\mathrm{NH}_{4}{ }^{+}$em solução nutritiva.

\begin{tabular}{|c|c|c|c|c|c|c|c|c|}
\hline \multirow{3}{*}{$\begin{array}{c}\begin{array}{c}\text { Proporção de } \\
\mathrm{NO}_{3}^{*} / \mathrm{NH}_{4}^{+} \\
(\%)\end{array} \\
100 / 0\end{array}$} & \multicolumn{6}{|c|}{ Espécies } & \multirow{2}{*}{\multicolumn{2}{|c|}{ Média }} \\
\hline & \multicolumn{2}{|c|}{ Gordura } & \multicolumn{2}{|c|}{ Marandu } & \multicolumn{2}{|c|}{ Tanzânia-1 } & & \\
\hline & 0,36 & $\mathrm{Ab}$ & 0,56 & $\mathrm{Aa}$ & 0,29 & $\mathrm{Ab}$ & 0,40 & A \\
\hline $75 / 25$ & 0,36 & $\mathrm{Ab}$ & 0,56 & $\mathrm{Aa}$ & 0,28 & $\mathrm{Ab}$ & 0,40 & $\mathrm{~A}$ \\
\hline $75 / 25(-\mathrm{Ca})$ & 0,24 & $\mathrm{Aab}$ & 0,33 & $\mathrm{Ba}$ & 0,17 & $\mathrm{Ab}$ & 0,25 & B \\
\hline $50 / 50$ & 0,29 & $\mathrm{Ab}$ & 0,64 & $\mathrm{Aa}$ & 0,32 & $\mathrm{Ab}$ & 0,42 & A \\
\hline $25 / 75$ & 0,31 & $\mathrm{Aa}$ & 0,36 & $\mathrm{Ba}$ & 0,23 & $\mathrm{Aa}$ & 0,30 & $\mathrm{~B}$ \\
\hline Média & 0,31 & $\mathrm{~b}$ & 0,49 & $\mathrm{a}$ & 0,26 & $\mathrm{~b}$ & 0,35 & \\
\hline
\end{tabular}

- C.V. $=19,2 \%$

- DMS Tukey a 5\% (média entre espécies e entre proporções) $=0,06$ e 0,09

- DMS Tukey a 5\% (proporções dentro de espécie e espécies dentro de proporção) $=0,16$ e 0,14

- Valores das colunas seguidos das mesmas letras maiúsculas e das linhas por letras minúsculas não diferem entre si. 
Tabela 43 Concentração de magnésio (em porcentagem) na matéria seca dos colmos + bainhas dos capins gordura, Marandu e Tanzânia-1 sob proporções de $\mathrm{NO}_{3}^{-}$e $\mathrm{NH}_{4}^{+}$em solução nutritiva.

\begin{tabular}{|c|c|c|c|c|c|c|c|c|}
\hline \multirow{3}{*}{$\begin{array}{c}\text { Proporção de } \\
\mathrm{NO}_{3}^{-} / \mathrm{NH}_{4}^{+} \\
(\%)\end{array}$} & \multicolumn{6}{|c|}{ Espécies } & \multirow{2}{*}{\multicolumn{2}{|c|}{ Média }} \\
\hline & \multicolumn{2}{|c|}{ Gordura } & \multicolumn{2}{|c|}{ Marandu } & \multicolumn{2}{|c|}{ Tanzânia-1 } & & \\
\hline & 0,15 & $\mathrm{Ab}$ & 0,25 & $\mathrm{Aa}$ & 0,29 & $\mathrm{Aa}$ & 0,23 & $\mathrm{~A}$ \\
\hline $75 / 25$ & 0,12 & $\mathrm{ABb}$ & 0,25 & $\mathrm{Aa}$ & 0,28 & $\mathrm{Aa}$ & 0,22 & A \\
\hline $75 / 25(-\mathrm{Ca})$ & 0,09 & $\mathrm{Bb}$ & 0,17 & $\mathrm{Ba}$ & 0,13 & $\mathrm{Bab}$ & 0,13 & $\mathrm{~B}$ \\
\hline $50 / 50$ & 0,13 & $\mathrm{ABb}$ & 0,28 & $\mathrm{Aa}$ & 0,27 & $\mathrm{Aa}$ & 0,23 & $\mathrm{~A}$ \\
\hline $25 / 75$ & 0,14 & $\mathrm{ABc}$ & 0,20 & $\mathrm{Bb}$ & 0,29 & $\mathrm{Aa}$ & 0,21 & $\mathrm{~A}$ \\
\hline Média & 0,13 & c & 0,23 & b & 0,25 & $\mathrm{a}$ & 0,20 & \\
\hline
\end{tabular}

- DMS Tukey a 5\% (média entre espécies e entre proporções) $=0,02$ e 0,03

- DMS Tukey a $5 \%$ (proporções dentro de espécie e espécies dentro de proporção) $=0,05$ e 0,05

- Valores das colunas seguidos das mesmas letras maiúsculas e das linhas por letras minúsculas não diferem entre si.

Tabela 44. Concentração de magnésio (em porcentagem) na matéria seca das raízes dos capins gordura, Marandu e Tanzânia-1 sob proporções de $\mathrm{NO}_{3}{ }^{-}$e $\mathrm{NH}_{4}^{+}$em solução nutritiva.

\begin{tabular}{|c|c|c|c|c|c|c|c|c|}
\hline \multirow{3}{*}{$\begin{array}{c}\begin{array}{c}\text { Proporção de } \\
\mathrm{NO}_{3}^{-} / \mathrm{NH}_{4}^{+} \\
(\%)\end{array} \\
100 / 0\end{array}$} & \multicolumn{6}{|c|}{ Espécies } & \multirow{2}{*}{\multicolumn{2}{|c|}{ Média }} \\
\hline & \multicolumn{2}{|c|}{ Gordura } & \multicolumn{2}{|c|}{ Marandu } & \multicolumn{2}{|c|}{ Tanzânia-1 } & & \\
\hline & 0,06 & $\overline{\mathrm{ABa}}$ & 0,03 & $\mathrm{BCa}$ & 0,10 & $\overline{\mathrm{Aa}}$ & 0,06 & $\mathrm{BC}$ \\
\hline $75 / 25$ & 0,03 & $\mathrm{ABb}$ & 0,11 & $\mathrm{Ba}$ & 0,11 & $\mathrm{Aa}$ & 0,08 & $\mathrm{~B}$ \\
\hline $75 / 25(-\mathrm{Ca})$ & 0,01 & $\mathrm{Ba}$ & 0,01 & $\mathrm{Ca}$ & 0,04 & $\mathrm{Aa}$ & 0,02 & $\mathrm{C}$ \\
\hline $50 / 50$ & 0,12 & $\mathrm{Ab}$ & 0,22 & $\mathrm{Aa}$ & 0,13 & $\mathrm{Ab}$ & 0,16 & $\mathrm{~A}$ \\
\hline $25 / 75$ & 0,12 & $\mathrm{Aa}$ & 0,11 & $\mathrm{Ba}$ & 0,11 & $\mathrm{Aa}$ & 0,11 & $\mathrm{AB}$ \\
\hline Média & 0,07 & $\mathrm{a}$ & 0,10 & $\mathrm{a}$ & 0,10 & $\mathrm{a}$ & 0,09 & \\
\hline
\end{tabular}

- C.V. $=45,2 \%$

- DMS Tukey a $5 \%$ (média entre espécies e entre proporções) $=0,04$ e 0,05

- DMS Tukey a $5 \%$ (proporções dentro de espécie e espécies dentro de proporção) $=0.10$ e 0,08

- Valores das colunas seguidos das mesmas letras maiúsculas e das linhas por letras minúsculas não diferem entre si. 


\subsubsection{Efeito das proporções de nitrato e amônio sobre a concentração de enxofre nos tecidos vegetais}

A concentração de enxofre na parte aérea (Tabela 45) apresentou diferença significativa $(\mathrm{P}<0,05)$ na comparação das médias para as proporções de nitrato e amônio, tendo valor mais elevado para o tratamento 75/25 (-Ca). Os mais baixos teores de enxofre na parte aérea ocorreram em presença de cálcio e nas mais altas concentrações de nitrato na solução. Não se constatou diferença significativa para as espécies $(P>0,05)$ na concentração de enxofre na parte aérea das folhas novas. Estes resultados estão de acordo com os de KIRKBY (1967); BLAIR et al. (1970); COX \& REISENAUER (1973) e FERNANDES \& ROSSIELO (1986), e reforçam a hipótese do maior consumo de ânions quando a forma mais absorvida é o amônio.

Tabela 45. Concentração de enxofre (em porcentagem) na matéria seca da parte aérea dos capins gordura, Marandu e Tanzânia-1 sob proporções de $\mathrm{NO}_{3}{ }^{-}$e $\mathrm{NH}_{4}^{+}$em solução nutritiva.

\begin{tabular}{|c|c|c|c|c|c|}
\hline \multirow{2}{*}{$\begin{array}{c}\text { Proporção de } \\
\mathrm{NO}_{3}^{-} \mathrm{NH}_{4}^{+} \\
(\%)\end{array}$} & \multicolumn{3}{|c|}{ Espécies } & \multirow{2}{*}{\multicolumn{2}{|c|}{ Média }} \\
\hline & Gordura & Marandu & Tanzânia-1 & & \\
\hline $100 / 0$ & 0,14 & 0,15 & 0,15 & 0,12 & $\mathrm{BC}$ \\
\hline $75 / 25$ & 0,13 & 0,13 & 0,12 & 0,10 & $\mathrm{C}$ \\
\hline $75 / 25(-\mathrm{Ca})$ & 0,20 & 0,23 & 0,23 & 0,18 & $\mathrm{~A}$ \\
\hline $50 / 50$ & 0,26 & 0,18 & 0,18 & 0,13 & $\mathrm{~B}$ \\
\hline $25 / 75$ & 0,16 & 0,18 & 0,16 & 0,13 & $B$ \\
\hline Média & 0,13 & 0,13 & 0,14 & 0,13 & \\
\hline
\end{tabular}

- C.V. $=11,8 \%$

- DMS Tukey a $5 \%$ (média entre espécies e entre proporções) $=0,01$ e 0,02

- Valores das colunas seguidos das mesmas letras maiúsculas e das linhas por letras minúsculas não diferem entre si.

Os resultados para as concentrações de enxofre nas folhas novas, folhas velhas, colmos + bainhas e raízes são mostrados, respectivamente nas tabelas 46, 47, 48 e 49. As concentrações médias de enxofre foram iguais nos 
colmos + bainhas e nas raízes, e também iguais nas folhas velhas e folhas novas. A concentração de enxofre naquelas duas partes excedeu à destas últimas.

Tabela 46. Concentração de enxofre (em porcentagem) na matéria seca das folhas novas dos capins gordura, Marandu e Tanzânia-1 sob proporções de $\mathrm{NO}_{3}^{-}$e $\mathrm{NH}_{4}^{+}$em solução nutritiva.

\begin{tabular}{|c|c|c|c|c|c|}
\hline \multirow{2}{*}{$\begin{array}{c}\text { Proporção de } \\
\mathrm{NO}_{3}{ }^{-} / \mathrm{NH}_{4}^{+} \\
(\%)\end{array}$} & \multicolumn{3}{|c|}{ Espécies } & \multirow{2}{*}{\multicolumn{2}{|c|}{ Média }} \\
\hline & Gordura & Marandu & Tanzânia-1 & & \\
\hline $100 / 0$ & 0,10 & 0,13 & 0,15 & 0,13 & $\mathrm{BC}$ \\
\hline $75 / 25$ & 0,11 & 0,14 & 0,11 & 0,12 & $\mathrm{C}$ \\
\hline $75 / 25(-\mathrm{Ca})$ & 0,19 & 0,23 & 0,24 & 0,22 & $\mathrm{~A}$ \\
\hline $50 / 50$ & 0,11 & 0,17 & 0,21 & 0,16 & $\mathrm{~B}$ \\
\hline $25 / 75$ & 0,15 & 0,17 & 0,16 & 0,16 & $\mathrm{~B}$ \\
\hline Média & 0,13 & 0,17 & 0,17 & 0,16 & \\
\hline
\end{tabular}

- C.V. $=15,8 \%$

- DMS Tukey a 5\% (média entre espécies e entre proporções) $=0,02$ e 0.03

- Valores das colunas seguidos das mesmas letras maiúsculas e das linhas por letras minúsculas não diferem entre si.

Tabela 47. Concentração de enxofre (em porcentagem) na matéria seca das folhas velhas dos capins gordura, Marandu e Tanzânia-1 sob proporções de $\mathrm{NO}_{3}{ }^{-}$e $\mathrm{NH}_{4}^{+}$em solução nutritiva.

\begin{tabular}{|c|c|c|c|c|c|}
\hline \multirow{2}{*}{$\begin{array}{c}\text { Proporção de } \\
\mathrm{NO}_{3}^{-} \mathrm{NH}_{4}^{+} \\
(\%)\end{array}$} & \multicolumn{3}{|c|}{ Espécies } & \multirow{2}{*}{\multicolumn{2}{|c|}{ Média }} \\
\hline & Gordura & Marandu & Tanzânia-1 & & \\
\hline $100 / 0$ & 0,12 & 0,16 & 0,15 & 0,14 & $\overline{B C}$ \\
\hline $75 / 25$ & 0,11 & 0,12 & 0,10 & 0,11 & $\mathrm{C}$ \\
\hline $75 / 25(-\mathrm{Ca})$ & 0,21 & 0,24 & 0,22 & 0,22 & $\mathrm{~A}$ \\
\hline $50 / 50$ & 0,13 & 0,19 & 0,18 & 0,17 & $\mathrm{~B}$ \\
\hline $25 / 75$ & 0,12 & 0,16 & 0,13 & 0,13 & $\mathrm{C}$ \\
\hline Média & 0,14 & 0,17 & 0,16 & 0,16 & \\
\hline
\end{tabular}

- C.V. $=12,2 \%$

- DMS Tukey a 5\% (média entre espécies e entre proporções) $=0,02$ e 0,03

- Valores das colunas seguidos das mesmas letras maiúsculas e das linhas por letras minúsculas não diferem entre si. 
Tabela 48. Concentração de enxofre (em porcentagem) na matéria seca dos colmos + bainhas dos capins gordura, Marandu e Tanzânia-1 sob proporções de $\mathrm{NO}_{3}^{-}$e $\mathrm{NH}_{4}^{+}$em solução nutritiva.

\begin{tabular}{|c|c|c|c|c|c|}
\hline \multirow{2}{*}{$\begin{array}{c}\text { Proporção de } \\
\mathrm{NO}_{3}^{-} / \mathrm{NH}_{4}^{+} \\
(\%) \\
\end{array}$} & \multicolumn{3}{|c|}{ Espécies } & \multirow{2}{*}{\multicolumn{2}{|c|}{ Média }} \\
\hline & Gordura & Marandu & Tanzânia-1 & & \\
\hline $100 / 0$ & 0,14 & 0,15 & 0,19 & 0,17 & BC \\
\hline $75 / 25$ & 0,19 & 0,14 & 0,15 & 0,17 & $\mathrm{C}$ \\
\hline $75 / 25(-\mathrm{Ca})$ & 0,16 & 0,22 & 0,25 & 0,22 & A \\
\hline $50 / 50$ & 0,17 & 0,17 & 0,17 & 0,17 & $\mathrm{BC}$ \\
\hline $25 / 75$ & 0,19 & 0,20 & 0,20 & 0,19 & $\mathrm{AB}$ \\
\hline Média & 0,16 & 0,18 & 0,19 & 0,18 & \\
\hline
\end{tabular}

- C.V. $=17,2 \%$

- DMS Tukey a 5\% (média das espécies e das proporções) $=0,03$ e 0,04

- Valores das colunas seguidos das mesmas letras maiúsculas e das linhas por letras minúsculas não diferem entre si.

Tabela 49. Concentração de enxofre (em porcentagem) na matéria seca das raízes dos capins gordura, Marandu e Tanzânia-1 sob proporções de $\mathrm{NO}_{3}^{-} \mathrm{e}$ $\mathrm{NH}_{4}^{+}$em solução nutritiva.

\begin{tabular}{|c|c|c|c|c|c|}
\hline \multirow{2}{*}{$\begin{array}{c}\text { Proporção de } \\
\mathrm{NO}_{3}^{-} \mathrm{NH}_{4}^{+} \\
(\%)\end{array}$} & \multicolumn{3}{|c|}{ Espécies } & \multirow{2}{*}{\multicolumn{2}{|c|}{ Média }} \\
\hline & Gordura & Marandu & Tanzânia-1 & & \\
\hline $100 / 0$ & 0,19 & 0,16 & 0,12 & 0,16 & B \\
\hline $75 / 25$ & 0,19 & 0,17 & 0,12 & 0,16 & $\mathrm{~B}$ \\
\hline $75 / 25$ (-Ca) & 0,20 & 0,20 & 0,16 & 0,19 & $\mathrm{AB}$ \\
\hline $50 / 50$ & 0,22 & 0,22 & 0,17 & 0,20 & $\mathrm{~A}$ \\
\hline $25 / 75$ & 0,21 & 0,20 & 0,17 & 0,19 & $\mathrm{AB}$ \\
\hline Média & 0,20 & 0,19 & 0,15 & 0,18 & \\
\hline
\end{tabular}

- C.V. $=14,4 \%$

- DMS Tukey a $5 \%$ (média das espécies e das proporções) $=0,02$ e 0,04

- Valores das colunas seguidos das mesmas letras maiúsculas e das linhas por letras minúsculas não diferem entre si. 


\section{CONCLUSÕES}

Nas condições em que foi desenvolvido o presente trabalho, os resultados permitiram apresentar as seguintes conclusões:

1. Os níveis de nitrato utilizados nas soluções nutritivas proporcionaram aumentos no número de perfilhos, na produção de matéria seca da parte aérea, na concentração de nitrogênio total da matéria seca da parte aérea e das raízes, e na concentração de nitrato da parte aérea e das raízes;

2. A atividade da redutase do nitrato foi baixa para os períodos avaliados em todas as espécies, com valores crescentes para a elevação dos níveis de nitrato na solução;

3. As proporções de nitrato e amônio de 100/0\% e 75/25\% sem cálcio proporcionaram maiores produções de matéria seca e mais elevadas concentrações de nitrogênio que as demais proporções estudadas;

4. A omissão de cálcio na solução nutritiva com proporção de 75/25, proporcionou aumentos na produção de matéria seca da parte aérea, e nas concentrações de fósforo, enxofre e potássio e redução na concentração de magnésio;

5. Os capins Tanzânia-1 e Marandu apresentaram produções de matéria seca superiores a do capim-gordura; a concentração de nitrogênio é semelhante entre essas espécies nas duas formas de nitrogênio e o capim-Marandu apresentou os maiores acúmulos de nitrato nas raízes. 


\section{REFERÊNCIAS BIBLIOGRÁFICAS}

ADAMS, F. Nutritional imbalances and constrainst to plant growth on acid soils. Journal of Plant Nutrition, New York, 4(2): 81-7, 1981.

ALVIM, M. J.; BOTREL, M. de A.; VERNEQUE, R. da S.; SALVATI, J. A. Aplicação de nitrogênio em acessos de Brachiaria. 1. Efeito sobre a produção de matéria seca. Pasturas Tropicales, Cali, 12(2): 2-6, 1990.

ANDRADE, J. B. de; PEDREIRA, J. V. S.; HENRIQUE, W. Comparação de três capins da espécie Panicum maximum Jacq. (Colonião, Tobiatã e K-187 B) sob dois níveis de adubação nitrogenada. Boletim de Indústria Animal, Nova Odessa, 48(2): 77-82, 1991.

ANDRADE, S. R. M. Efeito da proporção $\mathrm{NH}_{4}{ }^{+} / \mathrm{NO}_{3}{ }^{-}$na composição da fração nitrogenada na atividade de enzimas de redução e assimilação de nitrogênio em plantas de capim-colonião (Panicum maximum Jacq). Viçosa, 1994. 49p. (M.S. - Universidade Federal de Viçosa).

ARROYO-AGUILÚ, J. A. \& COWARD-LORD, J. Mineral composition of 10 tropical forage grasses in Puerto Rico. Journal of Agriculture of University of Puerto Rico, Rio Piedras, 58(4): 426-36, 1974.

ASPIOLEA, J. L. \& ARTEAGA, O. Fertilización con $\mathrm{N}$ en tres especies de pastos. I. Influencia sobre los rendimientos y contenido mineral. Ciencia y Técnica en la Agricultura, Pastos y Forrajes, Habana, 1(2): 73-84, 1978. 
BENDIX, M.E.S.; FERNANDES, M.S.; ROSSIELO, R.O.P. Aspectos de la nutrición nitrogenada de Paspalum notatum Flügge, en respuesta a fuentes de nitrógeno e inhibictión de nitrificación. Turrialba, San Jose, 32(1): 3341, 1982.

BLAIR, G. J.; MILLER, M. H.; MITCHELL, W. A. Nitrate and ammonium as sources of nitrogen for corn and their influence on the intake of other ions. Agronomy Journal, Madison, 64(3): 530-2, 1970.

BOGDAN, A. V. Tropical pasture and fodder plants.. New York, Longman, 1977. $465 \mathrm{p}$.

BOTREL, M. de A.; ALVIM, M. J.; MARTINS, C. E. Aplicação de nitrogênio em acessos de Brachiaria. 2. Efeito sobre os teores de proteína bruta e minerais. Pasturas Tropicales, Cali, 12(2): 7-10, 1990.

BRUNET, E.; ASPIOLEA, J. L.; ÁLVILA, A.; ALMAGUER, J. Respuesta de cuatro gramineas a la fertilizacion nitrogenada bajo condiciones de secano. III. Exportacion y efectos sobre el suelo. Ciencia y Técnica en la Agricultura, Suelos y Agroquimica, Habana, 11(3): 25-34, 1988 a.

BRUNET, E.; ASPIOLEA, J. L.; RIOS, C.; ÁVILA, A. Respuesta de cuatro gramineas a la fertilization nitrogenada bajo condiciones de secano. II. Composicion quimica. Ciencia y Técnica en la Agricultura, Suelos y Agroquímica, Habana, 11(3): 17-24, 1988b.

BRUNET, E.; AVILA, A.; RIOS, C.; ALMAGUER, J. Respuesta de cuatro gramineas a la fertilizacion con nitrogeno bajo condiciones de regadio. Ciencia y Técnica en la Agricultura, Suelos y Agroquímica, Habana 13(1): 43-52, 1990.

CAMPBELL, W. H . Nitrate reductase and its role in nitrate assimilation in plants. Physiologia Plantarum, Copenhagen, 74(2): 214-9, 1988. 
CARO-COSTAS, R.; VICENTE-CHANDLER, J.; FIGARELLA, J . The yield and composition of five grasses growing in the Humid Montains of Puerto Rico as affected by nitrogen fertilization, season and harvest procedure. Journal of Agriculture of the University of Puerto Rico, Rio Piedras, 44(3):107-20, 1960.

CARVALHO, M. M. \& SARAIVA, O. F. Resposta do capim-gordura (Melinis minutiflora Beauv.) à aplicação de nitrogênio, em regime de cortes. Revista da Sociedade Brasileira de Zootecnia, Viçosa, 16(5): 442-54, 1987.

CAUSIN, H. F.; BARNEIX, A. J.; GUITMAN, M. R. Effect of long term $\mathrm{NH}_{4}^{+}$ nutrition on growth and yield of wheat plants. Turrialba, San Jose, 42(4): 451-8, 1992.

CIAT. INFORME ANUAL, 1983. Programa de pastos tropicales. Cali, 1984. p. 251-66.

CORSI, M. Adubação nitrogenada das pastagens. In: SIMPÓSIO SOBRE MANEJO DE PASTAGENS, 2., Piracicaba, 1975. Anais, editado por A. M. Peixoto e outros. Piracicaba, FEALQ, 1975. p.112-35.

CORSI, M.; BALSALOBRE, M. A.; SANTOS, P. M.; SILVA, S. C. da. Bases para o estabelecimento do manejo de pastagens de braquiária. In: SIMPÓSIO SOBRE MANEJO DE PASTAGENS, 11., Piracicaba, 1994. Anais, editado por A. M. Peixoto e outros. Piracicaba, FEALQ, 1994 p. 249-66.

COX, W. J. \& REISENAUER, H. M. Growth and ion uptake by wheat supplied nitrogen as nitrate, or ammonium, or both. Plant and Soil, The Hague, 38(1/3): 368-80, 1973. 
CRESPO, G. Variation in the response of tropical pastures to nitrogenous fertilizers throughout the year. 3. Guinea grass (Panicum maximum Jacq.) with irrigation. Cuban Journal Agriculture Science, Habana, 20(1):73-81, 1986.

CRESPO, G.; ASPIOLEA, J. L.; LOPEZ, M. Nutricion de pastos. In: SISTACHS, M., ed. Los pastos en Cuba. Havana, Edica, 1986. t.1: Produccion, p. 345-416.

COWARD-LORD, J.; ARROYO-AGUILÚ; GARCIA-MOLINARI， O. Proximate nutriente composition of 10 tropical forage grasses. Journal of Agriculture of University of Puerto Rico, Rio Piedras, 58(3): 305-11, 1974.

EMPRESA BRASILEIRA DE PESQUISA AGROPECUÁRIA. Centro Nacional de Pesquisa de Gado de Corte. Brachiaria brizantha cv. Marandu. Campo Grande, MS, 1985. $31 \mathrm{p}$.

FERNANDES, M.S. \& FREIRE, L.R. Efeitos de nitrogênio nítrico aplicado ao solo na atividade de nitrato-redutase e na acumulação de $\mathrm{N}$-solúvel em Brachiaria sp. Turrialba, San Jose, 26(3): 268-73, 1976.

FERNANDES, M.S. \& FREIRE, L.R. Efeitos da interação de $\mathrm{N}^{-\mathrm{NO}_{3}}$ e $\mathrm{NH}_{4}$ na atividade da nitrato redutase e acumulação de N-proteico com Brachiaria sp. Turrialba, SanJose, 28(3): 187-91, 1978.

FERNANDES, M.S. \& ROSSIELO, R.O.P. Aspectos do metabolismo e utilização do nitrogênio em gramíneas tropicais. In: SIMPÓSIO SOBRE CALAGEM E ADUBAÇÃO DE PASTAGENS, 1., Nova Odessa,1985. Anais, editado por H. B. Mattos e outros. Piracicaba, POTAFOS, 1986. p. 93-123. 
FERNANDES, M.S.; ROSSIELO, R.O.P.; ARRUDA, M. L. R. Relações entre capacidade de troca de cátions das raízes e toxidez de alumínio em duas gramíneas forrageiras. Pesquisas Agropecuária Brasileira, Brasília, 19(5): 631-7, 1984.

FRANÇA, A. F. S. \& HAAG, H. P. Nutrição mineral em gramíneas tropicais. 1. Carências nutricionais em capim tobiatã (Panicum maximum Jacq). Anais da Escola Superior de Agricultura "Luiz de Queiroz", Piracicaba, 42(1): 83-96, 1985.

GHISI, O. M. A.; ALMEIDA, A. R. P. de; AlCÂNTARA, V. de B. G. Avaliação agronômica de seis cultivares de Panicum maximum Jacq sob três níveis de adubação. Boletim de Indústria Animal, Nova Odessa, 46(1): 1$15,1989$.

GLENN, B.P.; ELY, D.G.; GLENN, S.; BOLING, J.A.; BUSH, L.P. Effects of ammoniun nitrate and potassium sulfate fertilization on amino acid composition of tall fescue and orchardgrass. Journal of Plant Nutrition, New York, 8(5): 405-54, 1985.

GOMIDE, J. A. Estudo em pequenas parcelas sobre a fertilização do capimgordura, Melinis minutiflora Pal de Beauv. Revista Ceres, Viçosa, 13(75): 165-81, 1966.

HAGEMAN, R.H. \& BELOW, F.E. Role of nitrogen metabolism in crop productivity. In: ABROL, Y.P. ed. Nitrogen in higher plants. Somerset, England Research Studies, 1990. p 313-34.

HAGEMAN, R.H. \& FLESHER, P. Nitrate reductase activity in corn seedlings as affected by light and nitrate content of nutrient media. Plant Physiology, Rockville, 35(5): 700-8, 1960. 
HEIMER, Y.M. \& FILNER, P. Regulation of the nitrate assimilation pathway in cultured tobacco cells. III- The nitrate uptake system. Biochimica et Biophysica Acta, Amsterdan, 215(1): 152-65, 1970.

IMPITHUKSA, V. \& BLUE, W. G. Fertilizer nitrogen and nitrogen-15 in three warm-season grasses grown on a Florida spodosol. Soil Science Society of American Journal, Wisconsin, 49(5): 1201-4, 1985.

JARREL, W. M. \& BEVERLEY, R. B. The diluition effect in plant nutrition studies. Advances in Agronomy, New York, 34(1): 197-224, 1981.

KIRKBY, E. A. Influence of ammonium nitrate nutrition on the cation-anion balance and nitrogen and carbohydrate metabolism of plants grown in dilute nutrient solutions. Soil Science, The Hague, 105(3): 133-41, 1968.

LA HABA, M.; AGUERA, E.; MALDONADO J.M. Development of nitrogenassimilating enzimes in sunflower cotyledons during germination as affected by the exogenous nitrogen source. Planta, Berlim, 173(1): 52-7, 1988

LAYZELL, D.B. $\mathrm{N}_{2}$ fixation, $\mathrm{NO}_{3}-$ reduction and $\mathrm{NH}_{4}^{+}$assimilation. In: DENNIS, D.T. \& TURPIN, D.H. eds. Plant physiology, biochemistry and molecular biology. London, Longman Scientific and Technical, 1990. p. 389-406.

LEWIS, O. A. M. \& CHADWICK, S. An ${ }^{15} \mathrm{~N}$ investigation into nitrogen assimilation in hidroponically - grown barly (Horderum vulgare L. cv. Clipper) in response to nitrate, ammonium and mixed nitrate and ammonium nutrition, New Phytologist, London, 95(4): 635-46, 1983.

LEWIS, O.A.M.; JAMES D.N.; HEWITT, E.J. Nitrogen assimilation in barley (Hordeum vulgare 1. cv. Mazurka) in response to nitrate and ammonium nutrition. Annals of Botany, London, 49(1): 39-49, 1982. 
LEYSHON, A.J.; CAMPBELL, C.A.; WARDER, F.G. Comparation of the effect of $\mathrm{NO}_{3}{ }^{-}$and $\mathrm{NH}_{4}{ }^{+}-\mathrm{N}$ on growth, yield and yield components of manitou spring wheat and conquest barley. Canadian Journal of Plant Science, Ottawa, 60(4): 1063-70, 1980.

LUISI, M. V. V.; ROSSIElO, R. O. P.; FERNANDES, M. S. Formas de nitrogênio e níveis de potássio sobre a absorção de fósforo por milho. Pesquisa Agropecuária Brasileira, Brasília, 18(3): 343-50, 1983.

MALAVOLTA, E. Elementos de nutrição mineral de plantas. São Paulo, Agronômia Ceres, 1980. 251p.

MENGEL, K. \& KIRKBY, E. Principles of plant nutrition. 4. ed. Bern, International Postash Institute, 1987. 687 p.

MIDDLETON, C. H. Dry matter and nitrogen changes in five tropical grasses as influenced by cutting height and frequency. Tropical Grasslands, Brisbane, 16(3): 112-7, 1982.

MONTEIRO, F. A.; LIMA, S. A. A.; WERNER, J. C.; MATTOS, H. B. Adubação potássica em leguminosas e em capim-colonião (Panicum maximum Jacq.) adubado com níveis de nitrogênio ou consorciado com leguminosas. Boletim de Indústria Animal, Nova Odessa, 37(1): 127-48, 1980.

MONTEIRO, F.A.; RAMOS, A.K.B.; CARVALHO, D.D.; ABREU, J.B.R.; DAIUB, J.A.S.; SILVA, J.E.P.; NATALE, W. Cultivo de Brachiaria brizantha cv. Marandu em solução nutritiva com omissão de macronutrientes. Scientia Agrícola, Piracicaba, 51, 1994. (no prelo).

MULDER, E. G.; BOXMA, R.; VAN VEEN, W. L. Nitrate reduction in plant tissue. Plant and Soil, The Hague, 10(3): 335-55, 1959. 
NAIR, T. V. R. \& CHATERJEE, S. R. Nitrogen metabolism in cereals - Case studies in wheat, rice, maize and barley. In: ABROL, Y. P. ed. Nitrogen in higher plants. Somerset, England, Research Studies, 1990. p. 367-426.

NAMBIAR, P.T.C.; REGO, T.J.; RAO, B.S. Nitrate concentration and nitrate reductase activity in the leaves of three legumes and three cereals. Annals of Applied Biology, Warwick, 112(3): 547-53, 1988.

NOVOA, R. \& LOOMIS, R.S. Nitrogen and plant production. Plant and Soil, The Hague, 58(1-3): 177-204, 1981.

OLSEN, F. J. Effect of large applications of nitrogen fertilizer on the productivity and protein content of four tropical grasses in Uganda. Tropical Agriculturist, Trinidad Tobago, 49(3): 251-9, 1972.

OTERO, D. R. Informações sobre algumas plantas forrageiras. Rio de Janeiro, Serviço de Informação Agrícola, 1961. 334 p.

OSCARSON, P.; INGEMARSSON, B.; AF UGLASS, M.; LARSSON, C-M. Short-term studies of $\mathrm{NO}_{3}{ }^{-}$uptake in Pisum sativum using ${ }^{13} \mathrm{NO}_{3}^{-}$. Planta, Berlin, 170(5): 550-5, 1987.

PAERSE, P.J. \& WILMAN, D. Effects of applied nitrogen on grass leaf initiation, development and death in field swards. Journal of Agricultural Science, Cambridge, 103(2): 405-12, 1984.

PARETAS, J. J. Uso del nitrógeno em pastos tropicales. V. Aspectos que se han de considerar en la utilización del fertilizante nitrogenado. Ciencia y Técnica en la Agricultura, Pastos y Forrajes, Habana, 4(1): 59-95, 1981.

PATES, J.S. Uptake, asimilation and transport of nitrogen compounds by plants. Soil Biology and Biochemstry, Oxford, 5(2): 109 -19, 1972. 
PEDREIRA, J. V. S. Crescimento estacional dos capins colonião, gordura, jaraguá e pangola de Taiwan. Boletim de Indústria Animal, Nova Odessa, 30(1): 59-145, 1973.

PEDREIRA, J. V. S. \& MATTOS, H. B. Crescimento estacional de vinte e cinco espécies ou variedades de capins. Boletim de Indústria Animal, Nova Odessa, 38(2): 117-43, 1981.

QUEIROZ-FILHO, J. L.; SAIBRO, J. C.; RIBOLDI, J. Efeito do nitrogênio e dos regimes de corte sobre o acúmulo de nitrato em gramíneas forrageiras perenes de produção estival. Revista da Sociedade Brasileira de Zootecnia, Viçosa, 11(4): 734-45, 1982.

RAMOS, N.; HERRERA, R. S.; CURBELO, F. Regrowth age and nitrogen levels in star grass (Cynodon nlemfluensis). 2. Content of N, P, K, Ca and $\mathrm{Mg}$ and apparent $\mathrm{N}$ recovery. Cuban Journal of Agriculture Science, Habana, 17(1): 93-9, 1983.

ROSSIELO, R.O.P.; FERNANDES, M.S.; MAZUR, N. Efectos del desecamiento del suelo sobre el metabolismo de nitrógeno en tres cultivares de maiz (Zea mays L.). Turrialba, San Jose, 31(2): 227-35. 1981.

RUFTY, T.W.JR.; THOMAS, J.F.; REMMLEER, J.L.; CAMPBELL, W.H.; VOLK, R.J. Intracellular localization of nitrate reductase in roots. Plant Physiology, Rockville, 82(3): 675-80, 1986.

SARRUGE, J.R. Soluções nutritivas. Summa Phytopalogica, Jaguariúna, 1(3): 231-3, 1975.

SARRUGE, J.R. \& HAAG, H.P. Análises químicas em plantas. Piracicaba, ESALQ, 1974. $56 \mathrm{p}$. 
SCHRADER, L.E.; DOMSKA, D.; JUNG, P.E.; PETERSON, L.A. Uptake and assimilation of ammonium- $\mathrm{N}$ and nitrate- $\mathrm{N}$ and their influence on the growth of corn (Zea mays L.). Agronomy Journal, Madison, 64(5): 690-5, 1972.

SILVEIRA, J.A.G. Aspectos bioquímicos e fisiológicos da relação $\mathrm{K} / \mathrm{N}$ em canade-açucar (Saccharum sp) cv. - 5679, cultivada em solução nutritiva. Piracicaba, 1980. 127 p. (M.S. - Escola Superior de Agricultura "Luiz de Queiroz" / USP).

SILVEIRA, J.S.M. Crescimento e composição da fração nitrogenada solúvel em plantas de capim colonião (Panicum maximum Jacq) em função de várias proporções de nitrato/amônio. Viçosa, 1981. 36p. (M.S.- Universidade Federal de Viçosa).

SOTOMAYOR-RÍOS, A.; JULIÁ,F.J.; ARROYO-AGUILÚ, J.A. Effects of harvest intervals on the yield and competion of 10 forage grasses. Journal of the University of Puerto Rico, Rio Piedras, 58(3): 448- 55, 1974.

SOTOMAYOR-RÍOS, A.; MATIENZO, A. A.; FORTUÑO, J. V. Evaluation of seven forage grasses at two cutting stages. Journal of Agriculture of the University of Puerto Rico, Rio Piedras, 57(3): 173-85, 1973.

SOTOMAYOR-RÍOS, A.; VÉLEZ-SANTIAGO, J.; TORRES-RIVERA, S.; SILVA, S. Effect of three harvest intervals on yield and composition of nineteen forage grasses in humid montain region of Puerto Rico, Journal of the University of Puerto Rico, Rio Piedras, 60(3): 294-309, 1976.

SRIVASTAVA, H. S. Regulation of nitrate reductase activity in higher plants. Phytochemistry, London, 19(5): 725-33, 1980

SZODFRIDT, A. \& VARGA, J. The effect of $\mathrm{N}$ and $\mathrm{K}$ fertilizers on the $\mathrm{NO}_{3}$ content of different grass species and mixtures. In: INTERNATIONAL GRASSLAND CONGRESS, 16. Nice, 1989. Nice, 1989. p. 767-68. 
TAIZ, L. \& ZIEGER, E. Assimilation of mineral nutrients. In:___ Plant physiology. Redwood City, The Benjamin/Cumminggs Publ., 1991. p. 292317.

TEDESCO, M. J.; VOLKWEISS, S. J.; BOHEN, H. Análise de solos, plantas e outros materiais. Porto Alegre. Universidade Federal do Rio Grande do Sul, 1985. 188p. (Boletim Técnico, 5).

TILSDALE, S.L.; BEATON, J.D.; NELSON, J.L. Soil fertility and fertilizers. 4.ed. New York, MacMillan, 1985. 754 p.

VICENTE-CHANDLER, J. Intensive grassland management in Puerto Rico. Revista da Sociedade Brasileira de Zootecnia, Viçosa, 2(2): 173-215, 1972.

WERNER, J.C. Adubação de pastagens. Nova Odessa, Instituto de Zootecnia, 1986. 49 p. (Boletim Técnico, 18).

WHITEMAN, P.C. Tropical pasture science. New York, Oxford University Press, 1980. 392 p.

YONEYAMA, T.; YAMADA, H.; YAMAGATA, M.; KOUCH, H. Nitrate reduction and partioning of nitrogen in komatsuna (Brassica campestris $\mathrm{L}$. var. rapa) plants: compartmental analysis in combination with ${ }^{15} \mathrm{~N}$ tracer experiments. Plant Cell Physiology, Kyoto, 28(6): 679-96, 1989.

ZIELKER, H.R. \& FILNER, P. Synthesis and turnover of nitrate reductase induced by nitrate in cultured tobbaco cells. Journal of Biologic Chemistry, Baltimore, 246: 1172-9, 1971. 